\title{
WestVirginiaUniversity
}

THE RESEARCH REPOSITORY @ WVU

Graduate Theses, Dissertations, and Problem Reports

2020

\section{Three Essays in Public Economics}

Perry Ferrell

pmferrell@mix.wvu.edu

Follow this and additional works at: https://researchrepository.wvu.edu/etd

Part of the Political Economy Commons, and the Public Economics Commons

\section{Recommended Citation}

Ferrell, Perry, "Three Essays in Public Economics" (2020). Graduate Theses, Dissertations, and Problem Reports. 7601.

https://researchrepository.wvu.edu/etd/7601

This Dissertation is protected by copyright and/or related rights. It has been brought to you by the The Research Repository @ WVU with permission from the rights-holder(s). You are free to use this Dissertation in any way that is permitted by the copyright and related rights legislation that applies to your use. For other uses you must obtain permission from the rights-holder(s) directly, unless additional rights are indicated by a Creative Commons license in the record and/ or on the work itself. This Dissertation has been accepted for inclusion in WVU Graduate Theses, Dissertations, and Problem Reports collection by an authorized administrator of The Research Repository @ WVU.

For more information, please contact researchrepository@mail.wvu.edu. 
Graduate Theses, Dissertations, and Problem Reports

2020

Three Essays in Public Economics

Perry Ferrell

Follow this and additional works at: https://researchrepository.wvu.edu/etd

Part of the Political Economy Commons, and the Public Economics Commons 


\title{
THREE ESSAYS IN PUBLIC ECONOMICS
}

\author{
Perry Michael Ferrell
}

\author{
Dissertation submitted to the \\ Chambers College of Business and Economics \\ at West Virginia University \\ in partial fulfillment of the requirements for the degree of \\ Doctor of Philosophy \\ in \\ Economics
}

\author{
Joshua Hall, Ph.D., Committee Chairperson \\ Jack Dorminey, Ph.D. \\ Alexander Lundberg, Ph.D. \\ Bryan McCannon, Ph.D. \\ Department of Economics
}

Morgantown, West Virginia

2020

Keywords: Property Rights, Avalanche Forecasting, Newspapers, Policing

Copyright (C) 2020 Perry Ferrell 


\title{
ABSTRACT
}

\section{Three Essays in Public Economics}

\author{
by Perry Michael Ferrell
}

This dissertation investigates policy-relevant topics in public economics and law and economics. The first chapter applies the transitional gains trap to legal land title enfranchisement in developing countries. The second chapter examines the role of US Forest Service avalanche forecasting operations in preventing human-involved backcountry avalanche accidents. The final chapter explores what extent local newspaper coverage has on traffic stop behavior by local law enforcement.

In the first chapter "Titles For Me But Not For Thee: Transitional Gains Trap of Property Rights Extension in Colombia" I apply Tullock's "transitional gains trap" to the formalization of property titles in Latin America to understand public choice problems in institutional reform. In a country where land is governed by formal and informal institutions, policies to extend property rights will not be supported by voters holding legal title because it will devalue their properties. To test that prediction, I use data from Colombia where a peace deal to end a 50-year conflict with FARC (Revolutionary Armed Forces of Colombia) rebels was reached in 2016 and submitted to a public referendum. The deal included formalization of property titles across the nation as well as an end to the conflict. Using municipal-level data on voting and property ownership and controlling for the conflict's history, I find that potential losses to formal property holders pushed median voter preferences toward opposition. A $1 \%$ increase in legally titled land increases the dissenting vote share by three percentage points. These results are relevant to institutional reforms anywhere with corrupted property rights.

The second chapter is "Knowledge is Powder: Effect of Forecasting Services in Natural Hazard Management." When making decisions under uncertainty or engaging in risky behaviors, people rely on heuristics as well as information from outside sources. Does external information about a fluctuating risk reduce bad outcomes for risk takers? I examine this question using data from avalanche incidents in wintertime backcountry recreation. The number of people traveling in avalanche terrain in the United States has grown exponentially in the past 20 years, yet major avalanche accidents have remained relatively constant. Using data from reported avalanche incidents in Colorado and Utah, this paper shows that additional avalanche forecasting services reduce dangerous incidents. A policy change in Colorado allows for a difference-in-difference estimation with neighboring forecast centers, which gives causal estimates of forecasting reducing incidents by 42 percent on higher danger days. This reduction may be partially offset by an increase in incidents on lowest rated danger days.

The third chapter "Beat Cops and Beat Reporters: The impact of local press on taxation by citation" asks what inhibits the ability for governments to garner revenue from police issued fines? This paper investigates the role of print media in constraining bureaucrats from increasing revenues from non-traditional forms of taxation. Using data from seven million traffic stops in Illinois and a string of newspaper closings in the state, I find ticketing increases by local law enforcement after a closing. This causal estimate translates to roughly one additional ticket per day by a law enforcement department. 84 percent of the increase in citations are written to local drivers, the group that should receive the largest benefit from the newspaper. Citation leniency toward local residents is eliminated and residents are 23 percent more likely to be searched during a stop after newspaper closure. These results indicate that local media is effective in constraining government's ability to increase revenue through taxation by citation. 
To Bob, my grandfather. I would not have gone on to graduate school without your inspiration. Sorry graduation was cancelled. 


\section{Acknowledgments}

I would like to thank my comittee members Dr. Josh Hall, Dr. Bryan McCannon, Dr. Alex Lundberg, and Dr. Jack Dorminey for their invalualbe advice as well as all the faculty, fellow graduate students, and Karen Smith who have enriched my time at West Virginia University. I am grateful for the support from many resources at WVU especially the Center for Free Enterprise, as well as friends from the University and from the cycling community.

Signigcant portions of this work has been supported by the Property and Environment Research Center. I would like to thanks Josh P. Hill, Wally Thurman, Randy Rucker, and the many helpful individuals at PERC. I greatly appreciate Brian Yablonski, Bonnie Wilson, Dianna Rienhart and everyone else that welcomed me and loaned me office space to finish writing this dissertation. Additionally, I would like to thank the fellow graduate scholars, Andres Mendez, Casey Rozowski, and Henry Holmes for kindly providing feedback on the most recent thought in my head. For help with the second chapter I owe much gratitude for the knowledge, history, and data sharing from the avalanche forecasting community, especially Mike Cooperstien, Brian Lazar, Alex Marienthal, and Karl Birkeland.

Last but not least, I am grateful for the support from my family, Karen, Mickey, and Bob, as well as friends near and far. 


\section{Contents}

$\begin{array}{ll}\text { Abstract } & \text { ii }\end{array}$

Acknowledgments $\quad$ iv

List of Figures $\quad$ vii

List of Tables viii

1 Titles For Me But Not For Thee: Transitional Gains Trap of Property Rights

$\begin{array}{ll}\text { Extension in Colombia } & 1\end{array}$

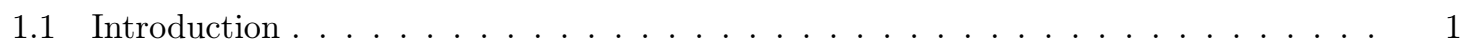

1.2 FARC, the Peace Deal, and the Referendum . . . . . . . . . . . . . . . 4

1.3 Transitional Gains Trap of Property Title Formalization . . . . . . . . . . . . . . . 7

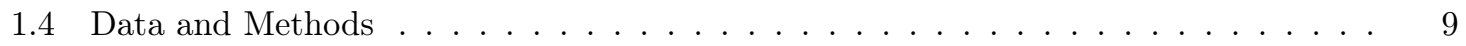

1.5 Effects on Voting Outcomes . . . . . . . . . . . . . . . . . . 12

1.5.1 Political Controls . . . . . . . . . . . . . . . . . . . . . . . . . 15

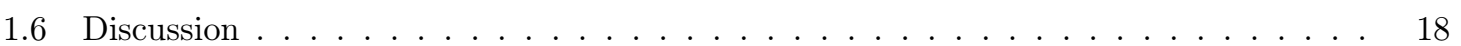

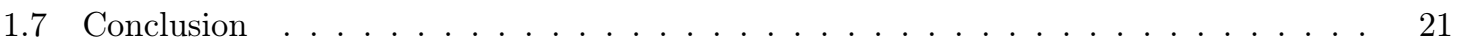

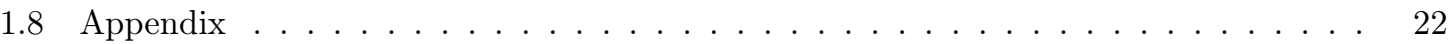

2 Knowledge is Powder: Effect of Forecasting Services in Natural Hazard Management 


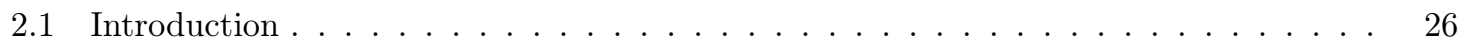

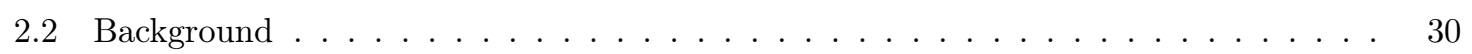

2.2 .1 History . . . . . . . . . . . . . . . . . . . . . . . . 31

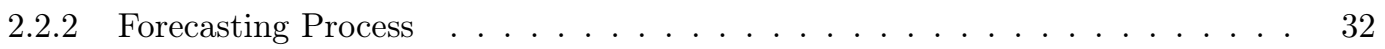

2.2.3 Backcountry Users, Private Investments in Safety, and the Avalanche Bulletin 33

2.2 .4 Colorado Season Extension $\ldots \ldots \ldots$. . . . . . . . . . . . 36

2.3 Data . . . . . . . . . . . . . . . . . . . . . . 36

2.4 Methods and Empirical Results . . . . . . . . . . . . . . . . . . . . . . 42

2.4.1 Control Variable Selection . . . . . . . . . . . . . . . . . . . . . 44

2.4.2 Colorado Season Extension Difference in Differences . . . . . . . . . . . . 45

2.4 .3 Robustness . . . . . . . . . . . . . . . . . . . . . . 47

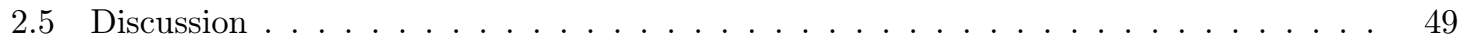

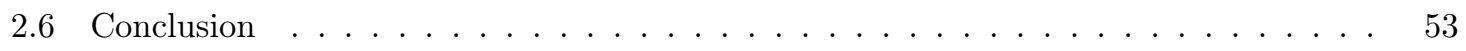

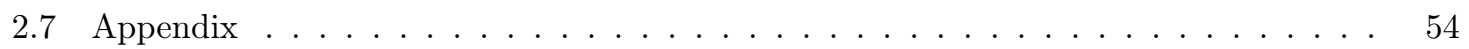

3 Beat Cops and Beat Reporters: The impact of local press on taxation by citation 61

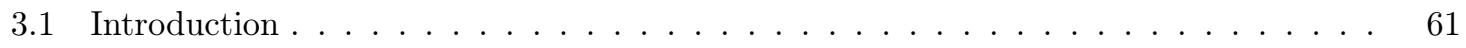

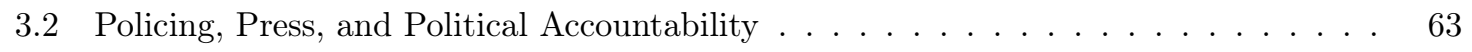

3.3 Stop Data and Newspaper Closures . . . . . . . . . . . . . . . . . . . . . 67

3.4 Empirical Results . . . . . . . . . . . . . . . . . . . . . . 70

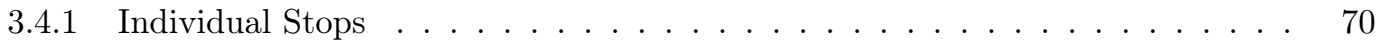

3.4 .2 Aggregated Stops . . . . . . . . . . . . . . . . . . . . 70

3.5 Residency Status . . . . . . . . . . . . . . . . . . . . . . . 72

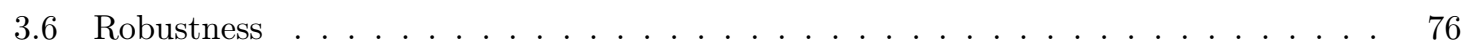

3.6.1 Automobile Accidents . . . . . . . . . . . . . . . . . 76

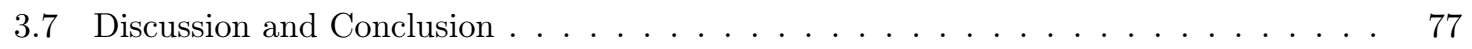

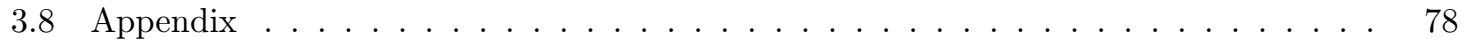




\section{List of Figures}

1.1 No Voting Distributions $\ldots \ldots \ldots \ldots \ldots$

2.1 Utah Zone Danger . . . . . . . . . . . . . . . . . . . . . 37

2.2 Colorado Zone Danger . . . . . . . . . . . . . . . . . . . . . . . . . 37

2.3 Incidents in Colorado in $\operatorname{Utah} \ldots \ldots \ldots \ldots$

2.4 Average reported avalanches and incidents across season in Colorado . . . . . . . . . 40

2.5 Incidents per danger rating $\ldots \ldots \ldots \ldots \ldots \ldots \ldots \ldots \ldots \ldots$

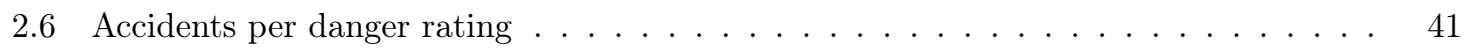

2.7 Total danger forecasted days distribution by state . . . . . . . . . . . . . 43

2.8 Average daily accident rate around closing date. . . . . . . . . . . . . . . . . 46

2.9 Persons caught in avalanches in Colorado and fatality rate . . . . . . . . . . . 51

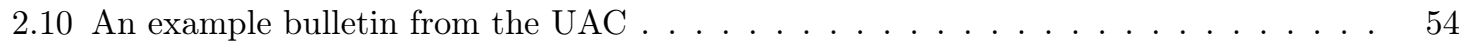

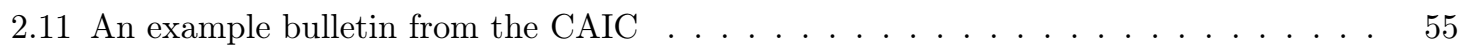

2.12 A sample (high quality) publicly submitted field report to the CAIC website $\ldots . .56$ 


\section{List of Tables}

1.1 Voting and Demographic Summary Statistics $(\mathrm{N}=914) \ldots \ldots \ldots \ldots$

1.2 Summary Statistics for Violence, annual averages $(\mathrm{N}=914) \ldots \ldots \ldots \ldots$

1.3 This table presents vote models controlling for overall violence. . . . . . . . . . . . 13

1.4 Land Ownership Quintile Regression . . . . . . . . . . . . . . . . . . . . . . 17

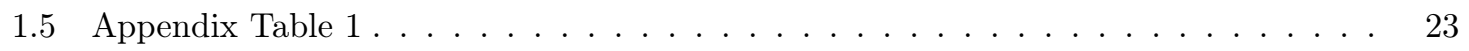

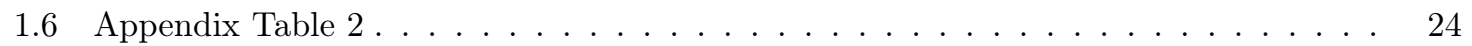

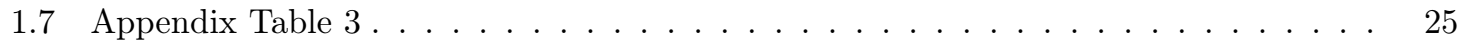

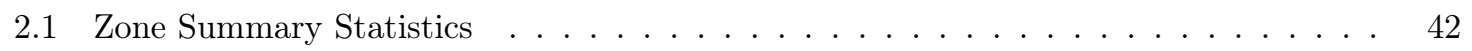

2.2 Panel models with weather controls . . . . . . . . . . . . . . . . . . . . 45

2.3 Difference in Differences Models . . . . . . . . . . . . . . . . . . . . . . . 47

2.4 Observation Reporting Rate Model . . . . . . . . . . . . . . . . . . . . . . . . . . . . 49

2.5 Weather Control Variables Selected by Elastic Net Procedure . . . . . . . . . . . . 57

2.6 Weather Control Variables Selected by LASSO Procedure . . . . . . . . . . . . . 58

2.7 Difference Model with level and Lasso selected controls . . . . . . . . . . . . . . . 59

2.8 Poisson Models of DiD Estimator . . . . . . . . . . . . . . . . . . . . . . 59

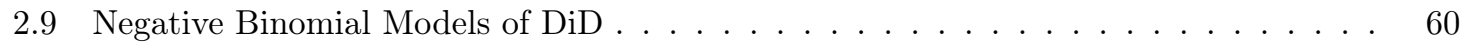

3.1 Individual Stop Summary Statistics _ . . . . . . . . . . . . . . . . . . 69

3.2 Department Monthly Summary Statistics _ . . . . . . . . . . . . . . . . . . . . 69

3.3 Individual Stop Level . . . . . . . . . . . . . . . . . . . . . . . . . . . . . . 71 
3.4 Monthly totals . . . . . . . . . . . . . . . . . . . . . . . . . . . 72

3.5 Residency Status in Individual Stops . . . . . . . . . . . . . . . . . . . . . . . . 73

3.6 Resident and Non-resident totals . . . . . . . . . . . . . . . . . . . . . . . 75

3.7 Automobile Accident DiD . . . . . . . . . . . . . . . . . . . . . . . . . 77

3.8 Individual Stop Models by Stop Purpose . . . . . . . . . . . . . . . . . . . . . . . . 79

3.9 Resident Ticket Lienency Models . . . . . . . . . . . . . . . . . . . . . . . . . . . . 80

3.10 Individual Stop Triple Difference Models . . . . . . . . . . . . . . . . . . . . . . . . 80

3.11 Triple Difference Aggregated Models . . . . . . . . . . . . . . . . . . . . . . . . . 81 


\section{Chapter 1}

\section{Titles For Me But Not For Thee: Transitional Gains Trap of Property Rights Extension in Colombia}

\section{$1.1 \quad$ Introduction}

It is seldom that economists argue against property rights since they are so crucial to economic growth (Acemoglu and Johnson, 2005). But if they are so important to prosperity, why do so many developing nations still lack strong property rights institutions? Extensive work stressing the importance of formal property titles for economic development and peace reached a broad audience with the work of Hernando de Soto and was continued by many others (De Soto, 1989, 2000). As institutions of public property ownership are implemented, they often fail to enfranchise all citizens, leaving rural farmers and urban migrants most affected. ${ }^{1}$ Understanding why country growth and investment in public institutions can fail to reach the full extension of property rights (Skaperdas, 1992) below affordable levels of public resource expenditures can be puzzling. Using evidence from recent events in Colombia, this paper seeks to explain why the democratic process can yield low levels of institutional property rights without substitute investment in private protection and institutions (Glaeser, Scheinkman, and Shleifer, 2003; Sonin, 2003).

\footnotetext{
${ }^{1}$ This is the case in Colombia where there is a mixture of formal land registration and informal property proprietorship
} 
Specifically, I use the intuition of the transitional gains trap (Tullock, 1975) to explain why democratic governments will fail to provide property rights protection to all citizens. ${ }^{2}$ In an economy where land is held by citizens by either formal or informal means, there will be differing equilibrium prices for the two different types of land. Formal land will carry a premium because it has less uncertainty associated with registration in public property institutions. As land is granted legal title, the one-for-one decrease in supply of informal land and increase in formal land will result in lower values of formal land. It is in a profit-maximizing formal landowner's best interest to prevent titling enfranchisement. ${ }^{3}$ Mixed property regimes create an interest group against institutional reform that can leave informal owners perpetually disenfranchised. I find evidence of this institutional transitional gains trap in referendum voting results in Colombia.

The ongoing conflict between leftist rebels and the Colombian government has affected millions and remains one of the deadliest and longest armed conflicts to have continued into the twenty-first century. The conflict is rooted in land ownership disputes and rural agrarians' lack of access to land. In 2016 the President of Columbia, Juan Manuel Santos, and the Revolutionary Armed Forces of Columbia (FARC), the largest of the rebel groups, reached a peace deal. In addition to peace terms with FARC, the deal included rural land reform measures such as a land fund for peasants and formalization of property titles. The Havana peace deal was put to a referendum in Colombia in October of 2016. The peace deal was rejected by the people, with 50.21 percent voting no (Colombian State Department, 2016). ${ }^{4}$ The referendum failed by less than 60,000 votes. A crucial part of the deal that extended beyond the conflict with FARC was property rights. Much property in rural Colombia is held without title or access to formal registry. This paper shows that the causes of the no vote against peace are partly rooted in the interests of formal landowners.

Prior literature explaining the persistence of wealth reducing institutions is theoretical in nature and mainly focused on economic institutions, like taxation (Acemoglu, 2006). I focus on property rights via land titling enfranchisement and use the referendum voting results in Colombia as my

\footnotetext{
${ }^{2}$ This requires the reasonable assumption that officials and their constituents are more likely to be formal property holders

${ }^{3}$ Assuming that titling informal land will have no effect on demand for formal land

${ }^{4}$ Ultimately several terms were renegotiated and the final peace accord was pushed through the Colombian Parliament and did not see referendum ballot
} 
empirical test to support this theory. There is a large literature establishing the avenues that property rights and specifically land titling improve economic growth and prosperity (Besley, 1995; Brasselle, Gaspart, and Platteau, 2002; Field, 2007; Galiani and Schargrodsky, 2010; Williamson and Mathers, 2011). The returns are large and property rights reform is a seemingly feasible domestic investment. Yet inefficient institutions remain because of institutional sclerosis (Olson, 2008), specifically the institutional transitional gains trap. This can be extended to explain the persistence of corrupted institutions over time in any governmental structure subject to interest group pressure. The research question is similar to the work of Kerekes and Williamson (2010) in Peru and Murtazashvili and Murtazashvili (2015) in Afghanistan. However, their work looks at localized methods of property rights as being efficient in explaining the lack of demand for formal institutions in certain regions. I study larger bureaucratic and political inefficiencies that hamper formal property institution enfranchisement, for which local informal institutions may serve as a substitute. This is similar to work in Kenya, where bureaucratic forces prevent optimal property rights' regimes (Leeson and Harris, 2018).

In the immediate analysis of the referendum results, a common story emerged in the press that higher socioeconomic status citizens voted against the deal (Alpert, 2016). It is not obvious why being on a higher income would cause a voter to prefer the continuation of conflict. Higher socioeconomic status citizens have gains from an end to the conflict. Wealthier families may be more likely to be targets of terrorism or kidnappings and incur higher taxes to fund the conflict. Yet the deal failed. The outcome in Colombia is not explained by the current research examining the political economy of property rights' reform. The investor class theory, supported by evidence from Mexican politics (Janvry, Gonzalez-Navarro, and Sadoulet, 2014) and a natural experiment in Argentina (Di Tella, Galiant, and Schargrodsky, 2007), suggests that property rights move individuals' political preferences rightward toward pro-market policies. Wealthier individuals who favor beneficial pro-market policies would gain from the extension of property rights to secure their political interests. This may explain why a center-right President Santos supported this part of the deal, but lack of support from wealthier voters remains a puzzle. The institutional transitional gains trap fills this void and does not require any assumptions about pro-market beliefs or a political spectrum. 
Evidence from Colombia shows a transitional gains trap of property rights extensions, even in the midst of a civil war. Tullock's transitional gains trap can answer why property rights reforms are slow to incorporate all land. Using municipal level ${ }^{5}$ referendum results and property ownership data, I find evidence to support this in the recent Colombian referendum. A 1 percent increase in legal farm titles in a municipality results in the no-vote share increasing by 3.5 percentage points. This referendum voting prevents confounding incentives from other elections because it was the only item on the ballot. This elicitation of stated preferences in Colombia can help explain the stalled formation of property rights institutions in Latin America and beyond where informal property remains the norm.

\subsection{FARC, the Peace Deal, and the Referendum}

Colombia has suffered perpetual conflict throughout the twentieth century; the current Colombian armed conflict began sometime between 1964 and 1966 involving many leftist guerrilla factions and the Colombian government. The most prominent of the rebel groups is FARC, which formed in 1964. All of these organizations have been classified terrorist organizations by the United States and the EU. In 2012 FARC representatives met with the Colombian government to establish a peace accord. There had been prior attempts at peace treaties but to no avail. Upon the beginning of the peace talks, FARC ceased major violent operations while the details of the deal were developed.

FARC is rooted in political activism from the early influence of the Colombian Communist Party, which found strong support in several rural regions. It followed a grassroots strategy of building political support from the local level with little concern for nationwide political influence. The deal to end the conflict provided the group the opportunity to transition to legitimate politics, and the Colombian government was willing to make this concession. This included creating five temporary seats in both the Colombian Senate and House of Representatives, as well as receiving government funds to finance their political campaign on a par with the allocations Colombia's major political parties receive. However, this was counterbalanced by 16 special electoral zones designed to represent

\footnotetext{
${ }^{5}$ In Colombia, municipalities are similar to US counties
} 
the areas hardest hit by conflict. ${ }^{6}$ These zones would offset the FARC seats for two terms, nullifying FARC's impact on the parliamentary process in Colombia.

Fighting with FARC has seen high levels of intensity in recent decades. In 2000 the Colombian government announced the start of a US-funded 'Plan Colombia.' These series of operations were to go in and combat both the leftist rebels and disrupt the cocaine trade (Otis, 2014). The operations were continued in the following administrations, though under different names, and they continued to receive US government support. In response to this, FARC launched a large 2006 operation in which it really first started using indiscriminate terror tactics. Previously most of their bombings and assassinations had been political, but this new series of attacks targeted civilians (Otis, 2014). While FARC continued to lose ground, in 2009 it resorted to full guerrilla tactics, including the heavy use of landmines to defend what territory it had left. Santos allegedly offered the rebels exemption from foreign extradition to bring them to the negotiating table in 2012. When negotiations began in Havana, a ceasefire was agreed, which drastically reduced FARC-incurred violence. The final deal made arrangements for permanent disarmament and the demobilization of FARC rebels.

The early years of the conflict saw more conventional warfare and guerrilla tactics, but over time FARC resorted to terrorist tactics as well as kidnapping, ransom, and narco-trafficking to finance its activities. This conflict has killed over 220,000 and left millions displaced (Registro Único de Víctimas, 2016). A popular source of revenue for FARC is the extortion of money from the civilian population of Colombia through kidnapping and ransom. FARC is extremely skilled at this and will hold a person until their family has sold off all of their assets to pay the ransom (Brittain, 2010). A section of the deal was focused on victim restitution and some punishment for combatants that committed war crimes. Additional concessions included a truth commission, a unit to search for missing persons, and measures for restitution of costs incurred in the course of the conflict. A special court to prosecute war crimes was also agreed upon. ${ }^{7}$ The original deal that was voted on had minimal punishment for combatants willing to confess their crimes. ${ }^{8}$

\footnotetext{
${ }^{6}$ In particular, many of these zones are designed to represent internally displaced persons, a community which FARC is very unpopular.

${ }^{7}$ Colombia has an intriguing history of minimal punishment for rebellion. The sentence for armed rebellion was 3 to 6 years in the penal code for much of the 20th century (Robinson, 2016).

${ }^{8}$ The slogan for Uribe's no vote campaign was "we want peace, but not this peace" stating demands for stiffer punishment of FARC rebels. However, it is important to note that as president, Uribe granted amnesty to 6000
} 
Colombia has a long and tumultuous history in the drug trade and Marxist rebel groups are not bereft of the industries profits. FARC has a large presence in the production and movement of coca and its finished product cocaine (Leech, 2011). FARC did not get directly involved with the early growth of the cocaine industry, instead levying taxes on narcos and establishing a rapport with peasants by ensuring they were paid in cash, not drugs. ${ }^{9}$ The cartels were unable to match FARC's military strength but soon were profitable enough that FARC was no longer overpowering. The FARC rebels jumped on board the cocaine boom in the 1980s in the US, turning it into their main revenue source. This was counter to their original ideological struggle but brought hundreds of millions of dollars in revenues (Richani, 2013). The coca trade allowed the FARC to increase their military strength to levels where it was a significant threat to the Colombian government. The process of building the cocaine trade by FARC, the cartels, and others has led to coca growing and processing being a major employer in certain regions across Colombia. For the peace deal to be lasting, transferring these laborers to legitimate industries was imperative, and a large part of the deal was focused on retooling this industry. However, the returns to narcotics greatly outweigh the legitimate substitutes for many involved in the narcotics trade. With this belief, even if FARC exits the narcotic industry, another group or cartel will replace it. ${ }^{10} \mathrm{I}$ argue this part of the deal has little traction.

There exists literature assigning the source of the current Colombian incursions to the disenfranchisement of land regimes that disadvantaged low-income agrarians (Fajardo, 2002; Grusczynski and Jaramillo, 2002). Land rights and conflict in Colombia had a history long before the formation of FARC. The FARC rebels originally organized themselves on a platform of land reform and rural development. While unequal land ownership sparked initial violence, forced displacement and outright land theft or occupation became frequent occurrences by combatants from Marxist groups, right-wing paramilitaries and cartels. Displacement and land occupation are associated with substantial welfare losses (Ibanez, 2009). These actions become permissible when property rights institutions are weak. Forced displacement and land theft can be exacerbated by programs designed to subsidize production

right-wing paramilitaries guilty of many atrocities during the course of the Colombian conflict.

${ }^{9}$ See Leech (2011) and Richani (2013) for further discussion of FARC's growth in the drug trade

${ }^{10}$ This was a frequent reason given by no voters for their lack of support. 
of legal crops instead of coca because substitute crops are not as labor intensive (Palacios, 2012). It follows from these persistent issues that land reforms were a necessary part of the deal, sewing together FARC's roots and tensions of continuing conflict. Quintessential to this is formalizing property ownership of 7 million $\mathrm{Hm}^{2}$ of land. According to the deal "implementation will be prioritized in the zones most affected by the conflict, areas with higher poverty levels, institutional weakness and the presence of crops made for illicit use" (Santos Calderón and Jiménez, 2016). According to the wording of the deal, the areas most affected by land titling will be rural zones. Given the emphasis on nationwide implementation and more certain outcomes, I believe this section of the deal is most relevant and consistent when examining voter preferences.

The final peace deal was put to a referendum set for October 2nd 2016. The Colombian FARC referendum was special because it was the only vote on the ballot. Voters were given a simple paper ballot that consisted of one question. The ballot translated as 'Do you support the final agreement to end the conflict and construct a stable and lasting peace?' There were no other elections on the ballot, so voting behavior can be examined without the uncertainty that stems from multiple choices in an election.

\subsection{Transitional Gains Trap of Property Title Formalization}

Large portions of land in Colombia have property title problems that prevent legal sales. Part of the peace deal to formalize property titles would increase the supply of land for sale. This dead capital (De Soto, 1989)being introduced to the market would drive down land values for those who currently own legal property. Current landowners may vote against the deal if the gains to ending the conflict are outweighed by the capitalization loss. Conversely, in areas where the median voter is more likely to be an informal property owner there should be more positive support for the deal.

This is similar to the transitional gains trap when property rights extensions create costs to current property rights holders. The core example used to propose the transitional gains trap was taxi-cab medallions. The institutional transitional gains trap uses the same logic as Tullock but 
replaces the quantity of taxi-cab medallions with formal property titles. ${ }^{11}$ Those with current free and clear titles have a vested interest in preventing an increase in formalized land. As more people own formalized land and the median voter becomes more likely to hold a clear title, with informal holders becoming a minority, it becomes politically impossible to free this dead capital. Granting formal land titles is understood as a method of reducing conflict (Albertus and Kaplan, 2013; Alston, Libecap, and Mueller, 2000; De Soto, 1989), but was politically unfeasible. It required a peace deal ending a 50-year conflict to develop clear land titles and overcome the institutional transitional gains trap.

Evidence on the ground of voters stating dissension because they were afraid property rights extension would damage their land value is hard to come by. However, a legal property owner has little incentive to voice this purely self-interested story. After all, when you ask a New York cabbie why they think Uber should be regulated, they do not tell you it is because they put up their medallion as collateral for their mortgage, but instead give some story of public interest.

Full land titling may not be reached because owners of informal property are content with the increase in the relative value of their land on the informal market that comes with reducing the supply of informal land. These owners do not choose to title land because the cost of titling outweighs the benefit received when others have titled their land and prices converge, and a persistent amount of informal land emerges as an equilibrium. I argue this is unlikely because of wealth increases provided by formal titling (Galiani and Schargrodsky, 2010). Additionally, formal land is more productive than informal land because of the incentives to invest in it (Goldstein and Udry, 2008) and maintain the land's resources (Alston, Libecap, and Mueller, 1999). Increased agricultural productivity is an additional return that formal owners may want to protect. Though in an efficient market this should be capitalized into the value of the land, formal land has a comparative advantage over informal land in agricultural productivity.

\footnotetext{
${ }^{11}$ See Tullock (1975) for further discussion
} 


\subsection{Data and Methods}

Data is sourced from the Colombian National Election Service (Colombian State Department, 2016) and the Universidad de los Andes Economcis Department Colombian municipal data set (Acevedo and Bornacelly, 2016). The latter is a panel from 1993-2012, which includes property ownership data, violence data by guerrilla groups, as well as other geographic and demographic control data. This data set is broken down by Municipio, and there are 1122 municipalities in the data set. The three primary dependent variables are the overall turnout of registered voters, the turnout of no-voters from registered voters, and the no-vote share. Primary explanatory variables of interest are the number of legally titled rural farms, the average size of those farms, and the percentage of informal land in each municipality.

$$
Y_{i}=\alpha+\gamma \text { LegalTitles }_{i}+\text { dlogParcelSize }_{i}+\phi \text { InformalProperty }_{i}+B X_{i}+\epsilon_{i}
$$

The X parameter captures control variables for each municipality including geographic, demographic, and socioeconomic characteristics of each municipality as well as controls for violence. The transitional gains trap model proposes that $\gamma$ parameter capturing legal titles will be positive for no voter turnout and no vote share, as well as parcel size because it captures the increasing opportunity cost of extending title franchise. The $\phi$ term captures the effect of percentage of informal land in a municipality, which should decrease no voter turnout and increase support for the deal.

The summary statistics in Table 1 provide the independent, dependent, and demographic control variables of interest. No Vote Share is the percentage of no votes scored in a municipality. Turnout No is the voter turnout rate of those casting no ballots, so the number of no ballots divided by the number of registered voters in a municipality. Total turnout is all ballots cast divided by registered voters. Referendum voting in Colombia has a quorum rule. For approval, a referendum must receive a turnout rate above 25 percent and pass by majority rule. I include the voter preference models 
Table 1.1: Voting and Demographic Summary Statistics $(\mathrm{N}=914)$

\begin{tabular}{lcccc}
\hline \hline Statistic & Mean & St. Dev. & Min & Max \\
\hline Registered Voters & $24,102.39$ & $62,703.71$ & 762 & $1,029,268$ \\
No Vote (\% total votes) & 0.48 & 0.16 & 0.05 & 0.85 \\
No Vote (\% registered voters) & 0.17 & 0.08 & 0.02 & 0.41 \\
Voter Turnout & 0.35 & 0.08 & 0.03 & 0.71 \\
Informal Land & 0.17 & 0.19 & 0.00 & 1.00 \\
Land Titles & $2,728.13$ & $2,405.03$ & 6 & 21,336 \\
Titles Per Voter & 0.23 & 0.24 & 0 & .99 \\
Average Prop Size & 44.94 & 124.41 & 0.99 & $1,681.60$ \\
GDP per capita & 7.62 & 6.18 & 0.01 & 80.10 \\
Ag GDP share & 0.26 & 0.19 & 0.0003 & 0.93 \\
Distance Market & 129.97 & 111.56 & 0.00 & 926.47 \\
Rural Population & 0.59 & 0.24 & 0.002 & 1.00 \\
Poverty & 0.69 & 0.16 & 0.14 & 1 \\
\hline
\end{tabular}

estimated on turnout measures because of the quorum rule.

The primary explanatory variables are also included in Table 1. Informal Land is the percentage of land in a municipality that is owned informally. Land Titles is the number of legally titled rural properties with agricultural designation, and this is also presented as legal titles per voter. Average property size is the mean square kilometers of the legally titled agricultural land in a municipality. This is included because the opportunity cost of extending legal titles may increase as the size of a parcel legally owned increases, all else being equal. These statistics are the most recently available measures, but one limitation is that the land statistics used are from data collected in 2010, although this should not add much error to the results. The cadastral survey in the rural areas of interest have not been updated since this data collection, so the current values at the time of the vote in 2016 are likely to have changed very little. Some municipalities had missing data, which are dropped from the analysis. The 914 municipalities with complete information that are used in regressions are 
presented in the summary statistics.

Table 1.2: Summary Statistics for Violence, annual averages $(\mathrm{N}=914)$

\begin{tabular}{lcccc}
\hline \hline Statistic & Mean & St. Dev. & Min & Max \\
\hline Terrorism & 3.1 & 8.6 & 0.0 & 91.0 \\
Abductions & 1.2 & 2.6 & 0.0 & 46.6 \\
Torture & 0.3 & 1.0 & 0.0 & 25.9 \\
Land theft & 4.9 & 15.3 & 0.0 & 198.2 \\
Landmine events & 0.5 & 1.6 & 0.0 & 19.6 \\
Child soldiers & 0.3 & 0.6 & 0.0 & 7.5 \\
Homicides & 33.1 & 104.7 & 0.0 & $2,970.4$ \\
Displaced & 319.1 & 725.2 & 0.0 & $12,486.0$ \\
Forced disappearance & 5.2 & 12.4 & 0.0 & 180.3 \\
Sex crimes & 0.6 & 1.5 & 0.0 & 22.5 \\
Threats & 14.6 & 41.8 & 0.0 & $1,061.8$ \\
Forced land abandon & 0.4 & 2.8 & 0.0 & 51.4 \\
Defensive actions & 4.8 & 14.5 & 0.0 & 274.1 \\
\hline
\end{tabular}

Table 1.2 provides the summary statistics for all reported incidents of the respective category as collected by the Colombia Registry of Victims. The summary statistics presented are totals over the available data from 1993-2015. Appendix Table 1 presents the summary statistics for FARC-specific violence over the same time period. Five, 10, and 15 years prior time horizons are also used and the primary results are unaffected. The land coefficients are also not altered when the variables are broken up into 5-year windows.

The impact of politics and conflict on voter preferences cannot be ignored. However, difficulty arises when attempting to control for conflict variables because these occur over time, and the dependent variable of interest is cross-sectional in nature. This is also confounded because violence variables are broken down by faction. Models are estimated using violence controls both aggregated across groups and FARC-specific. The results are robust to both specifications. Additionally, the 
correct way to normalize violent events is not obvious for many types, such as terrorist attacks, ambushes, landmines, and massacres. These variables are left as levels in the models presented; however, when adjusted for population, municipality $K M^{2}$, and population density the magnitude and significance of landownership variables of interest are unaffected.

\subsection{Effects on Voting Outcomes}


Table 1.3: This table presents vote models controlling for overall violence.

\begin{tabular}{|c|c|c|c|c|c|c|c|c|c|c|}
\hline & \multicolumn{2}{|c|}{ Percent No } & \multirow{2}{*}{$\begin{array}{c}\text { No Turnout } \\
(3)\end{array}$} & \multirow{2}{*}{$\begin{array}{c}\text { Total Turnout } \\
(4) \\
\end{array}$} & \multirow{2}{*}{$\begin{array}{c}\text { Percent No } \\
(5)\end{array}$} & \multirow{2}{*}{$\begin{array}{c}\text { No Turnout } \\
(6)\end{array}$} & \multirow{2}{*}{$\begin{array}{c}\text { Total Turnout } \\
\text { (7) }\end{array}$} & \multirow{2}{*}{$\begin{array}{c}\text { Percent No } \\
(8)\end{array}$} & \multirow{2}{*}{$\begin{array}{c}\text { No Turnout } \\
(9)\end{array}$} & \multirow{2}{*}{$\begin{array}{c}\text { Total Turnou } \\
(10)\end{array}$} \\
\hline & $(1)$ & $(2)$ & & & & & & & & \\
\hline (log)Legal Titles & $\begin{array}{c}3.73^{* * *} \\
(1.08)\end{array}$ & $\begin{array}{c}3.48^{* * *} \\
(1.03)\end{array}$ & $\begin{array}{c}1.75^{* * *} \\
(0.30)\end{array}$ & $\begin{array}{l}1.09^{* *} \\
(0.43)\end{array}$ & $\begin{array}{c}2.77^{* * *} \\
(1.00)\end{array}$ & $\begin{array}{c}1.46^{* * *} \\
(0.28)\end{array}$ & $\begin{array}{l}1.06^{* *} \\
(0.44)\end{array}$ & $\begin{array}{c}3.82^{* * *} \\
(1.14)\end{array}$ & $\begin{array}{c}1.74^{* * *} \\
(0.31)\end{array}$ & $\begin{array}{l}0.82^{*} \\
(0.46)\end{array}$ \\
\hline (log)Property Size & $\begin{array}{c}3.63^{* * *} \\
(0.59)\end{array}$ & $\begin{array}{c}3.27^{* * *} \\
(0.60)\end{array}$ & $\begin{array}{c}1.46^{* * *} \\
(0.26)\end{array}$ & $\begin{array}{c}0.33 \\
(0.28)\end{array}$ & $\begin{array}{c}3.09^{* * *} \\
(0.60)\end{array}$ & $\begin{array}{c}1.37^{* * *} \\
(0.25)\end{array}$ & $\begin{array}{c}0.24 \\
(0.28)\end{array}$ & $\begin{array}{c}3.41^{* * *} \\
(0.62)\end{array}$ & $\begin{array}{c}1.52^{* * *} \\
(0.26)\end{array}$ & $\begin{array}{c}0.36 \\
(0.28)\end{array}$ \\
\hline Informal Land & $\begin{array}{c}-0.18^{* * *} \\
(0.03)\end{array}$ & $\begin{array}{c}-0.18^{* * *} \\
(0.03)\end{array}$ & $\begin{array}{c}-0.03^{* *} \\
(0.01)\end{array}$ & $\begin{array}{c}0.06^{* * *} \\
(0.02)\end{array}$ & $\begin{array}{c}-0.16^{* * *} \\
(0.03)\end{array}$ & $\begin{array}{c}-0.03^{* *} \\
(0.01)\end{array}$ & $\begin{array}{c}0.05^{* * *} \\
(0.02)\end{array}$ & $\begin{array}{c}-0.18^{* * *} \\
(0.03)\end{array}$ & $\begin{array}{c}-0.03^{* *} \\
(0.01)\end{array}$ & $\begin{array}{c}0.06^{* * *} \\
(0.02)\end{array}$ \\
\hline FARC presence & $\begin{array}{l}0.23^{* *} \\
(0.10)\end{array}$ & $\begin{array}{c}0.42^{* * *} \\
(0.10)\end{array}$ & $\begin{array}{c}0.16^{* * *} \\
(0.05)\end{array}$ & $\begin{array}{l}0.11^{* *} \\
(0.05)\end{array}$ & $\begin{array}{c}0.41^{* * *} \\
(0.11)\end{array}$ & $\begin{array}{c}0.17^{* * *} \\
(0.05)\end{array}$ & $\begin{array}{l}0.10^{*} \\
(0.05)\end{array}$ & $\begin{array}{c}0.32^{* * *} \\
(0.10)\end{array}$ & $\begin{array}{c}0.13^{* * *} \\
(0.04)\end{array}$ & $\begin{array}{r}0.10^{* *} \\
(0.04)\end{array}$ \\
\hline Violence Controls & $\mathrm{N}$ & $\mathrm{Y}$ & $\mathrm{Y}$ & $\mathrm{Y}$ & & & & & & \\
\hline Violence Per Capita & $\mathrm{N}$ & & & & $\mathrm{Y}$ & $\mathrm{Y}$ & $\mathrm{Y}$ & & & \\
\hline Violence (Pop Density) & $\mathrm{N}$ & & & & & & & $\mathrm{Y}$ & $\mathrm{Y}$ & $\mathrm{Y}$ \\
\hline Demographic Controls & $\mathrm{Y}$ & $\mathrm{Y}$ & $\mathrm{Y}$ & $\mathrm{Y}$ & $\mathrm{Y}$ & $\mathrm{Y}$ & $\mathrm{Y}$ & $\mathrm{Y}$ & $\mathrm{Y}$ & $\mathrm{Y}$ \\
\hline Constant & $\mathrm{Y}$ & $\mathrm{Y}$ & $\mathrm{Y}$ & $\mathrm{Y}$ & $\mathrm{Y}$ & $\mathrm{Y}$ & $\mathrm{Y}$ & $\mathrm{Y}$ & $\mathrm{Y}$ & $\mathrm{Y}$ \\
\hline $\mathrm{N}$ & 914 & 914 & 914 & 914 & 914 & 914 & 914 & 914 & 914 & 914 \\
\hline Adjusted $\mathrm{R}^{2}$ & 0.34 & 0.38 & 0.46 & 0.37 & 0.39 & 0.46 & 0.37 & 0.35 & 0.44 & 0.37 \\
\hline Residual Std. Error & 12.91 & 12.50 & 5.59 & 6.19 & 12.43 & 5.58 & 6.18 & 12.82 & 5.67 & 6.17 \\
\hline F Statistic & $44.25^{* * *}$ & $24.74^{* * *}$ & $33.23^{* * *}$ & $23.08^{* * *}$ & $25.36^{* * *}$ & $33.44^{* * *}$ & $23.29^{* * *}$ & $21.70^{* * *}$ & $31.22^{* * *}$ & $23.39^{* * *}$ \\
\hline
\end{tabular}


This section presents the primary empirical results. Table 3 shows linear models with the dependent variables, no-vote share, no turnout, and total turnout with differing violence controls. All models control for demographics that include socioeconomic factors affecting demand for land titling, including GDP per capita, agriculture share of GDP, log of population, rural population, distance to market, and poverty rate. The estimates are consistent across all specifications. Increasing land held informally in a municipality by 1 percentage point can account for .15 -.21 percent less no vote share. ${ }^{12}$ The estimates for legal titles suggest that a 1 percent increase in rural legal farm titles increases the no-vote share by at least 2.5-3 percent. These estimates are significant and consistent across multiple specifications.

These rural agricultural parcels are most likely to be affected by the transitional gains trap because rural areas have higher rates of informal ownership and are the primary target of the deal terms. Increase in average parcel size of legal owners, which increases the opportunity cost of granting formal titles, leads to the proposed positive effect and is highly significant. The point estimates are similar for both no-vote share and no turnout. Possessing a legal land title brought out voters against the peace accords. This is suggestive of the transitional gains trap of extending property titles.

The most salient thing to control for that has been discussed is violence, but it is not the only pertinent confounding factor. I control for all the other parts of the peace deal to rule out other stories. A dummy variable for the presence of coca production is included to control for the impact of the coca trade transition section on voter preferences. The political transition part of the deal is much tougher, but a dummy for the presence of FARC guerrillas in the community is included. The control point estimates are available in Table 1.7. Generally, increased levels of violence contribute to support for the peace deal. Additionally, none of the violence control variables have a positive correlation with legal land titling. This suggests that it is unlikely that the effect of legal land titles in voting is being falsely attributed to the transitional gains trap because of targeted violence. Municipalities with higher levels of legal land titles experience less violence.

It is likely that the presence of FARC and support for FARC among the community are not

\footnotetext{
${ }^{12}$ One may be concerned with co-linearity between informal land estimates and legal ownership. Omitting informal ownership does not affect the legal title variables. State land is not included
} 
necessarily perfectly correlated, and this relationship varies across space. The top left panel of Figure 1 shows the distribution of voter support for the deal, contingent on the amount of FARC exposure. While a slight pattern is noticeable of lower support at the tails, no prevailing pattern exists. More work can be done here possibly using local election results from other campaigns.

The models specified in Table 1.6 use the same variables of interest, but controlling for violence specifically attributed to FARC. The results are consistent with controlling for overall conflict violence.

The losses to owners are probably not linear across the distribution of farm ownership. When the ratio of legally titled to informal land is low, those owners will incur higher drops in property values than an area where legally owned land far surpasses informal land. The semi-parametric estimation shown in the land titles scatter plot in Figure 1 is suggestive of this. In areas with high levels of formal ownership, the marginal impact of granting a plot formal title will be minimal on land values. Other preferences matter more explaining the diminishing effect beyond 25 percent in the top right panel. However, when formal ownership is low, a one-for-one increase in dissenting votes and legal titles is observed.

\subsubsection{Political Controls}

This vote was a highly political issue in Colombia. The peace process was brought about as a campaign promise by President Santos. There are possibly other highly correlated political preferences that could be confounding results. For example, if formal landowners did not like the tax policy of the Santos administration, they may also have voted against the peace deal out of distaste for Santos and not because they are voting to protect their property values.

While there was no other election occurring at the same time to confound results, these estimates are not causal. There could be other factors correlated with land ownership that drive dissension. Average income and the other demographic controls may not be sufficient. Any preferences that would falsely bias positive estimates of land ownership would likely manifest themselves in other electoral outcomes as well. 

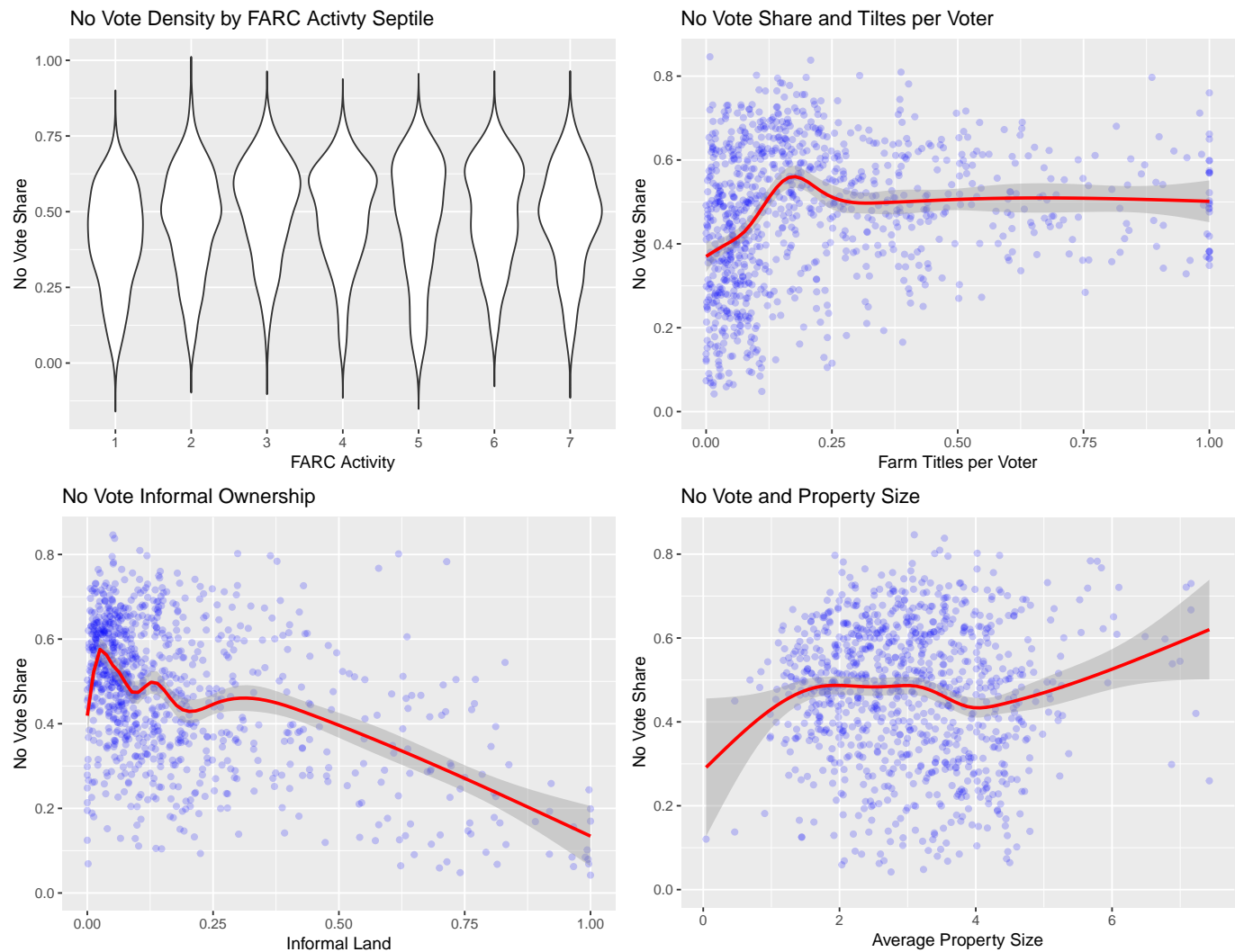

Figure 1.1: No Voting Distributions 
Table 1.4: Land Ownership Quintile Regression

\begin{tabular}{|c|c|c|c|c|}
\hline & \multicolumn{4}{|c|}{ Percent No } \\
\hline & (1) & $(2)$ & $(3)$ & $(4)$ \\
\hline Titles PC $(0,0.046]$ & $\begin{array}{c}-4.27^{* *} \\
(1.88)\end{array}$ & $\begin{array}{c}-4.01^{* *} \\
(1.92)\end{array}$ & $\begin{array}{l}-0.95 \\
(1.88)\end{array}$ & $\begin{array}{c}-4.76^{* *} \\
(1.90)\end{array}$ \\
\hline Titles PC $(0.046,0.099]$ & $\begin{array}{c}-2.91^{*} \\
(1.53)\end{array}$ & $\begin{array}{c}-2.62^{*} \\
(1.57)\end{array}$ & $\begin{array}{l}-0.34 \\
(1.53)\end{array}$ & $\begin{array}{c}-3.36^{* *} \\
(1.58)\end{array}$ \\
\hline Titles PC $(0.099,0.19]$ & $\begin{array}{l}2.27^{*} \\
(1.19)\end{array}$ & $\begin{array}{l}2.19^{*} \\
(1.22)\end{array}$ & $\begin{array}{c}3.78^{* * *} \\
(1.19)\end{array}$ & $\begin{array}{c}1.84 \\
(1.23)\end{array}$ \\
\hline Titles PC $(0.19,0.39]$ & $\begin{array}{c}2.89^{* * *} \\
(1.01)\end{array}$ & $\begin{array}{c}2.64^{* * *} \\
(1.02)\end{array}$ & $\begin{array}{c}3.29^{* * *} \\
(0.99)\end{array}$ & $\begin{array}{l}2.53^{* *} \\
(1.03)\end{array}$ \\
\hline Informal Land & $\begin{array}{c}-0.12^{\text {*** }} \\
(0.02)\end{array}$ & $\begin{array}{c}-0.12^{* * *} \\
(0.02)\end{array}$ & $\begin{array}{c}-0.09^{* * *} \\
(0.02)\end{array}$ & $\begin{array}{c}-0.12^{* * *} \\
(0.02)\end{array}$ \\
\hline (log)Property Size & $\begin{array}{c}2.77^{* * *} \\
(0.39)\end{array}$ & $\begin{array}{c}2.69^{* * *} \\
(0.40)\end{array}$ & $\begin{array}{c}2.38^{* * *} \\
(0.40)\end{array}$ & $\begin{array}{c}2.68^{* * *} \\
(0.40)\end{array}$ \\
\hline FARC presence & $\begin{array}{c}-0.16^{* *} \\
(0.06)\end{array}$ & $\begin{array}{c}0.01 \\
(0.07)\end{array}$ & $\begin{array}{l}-0.05 \\
(0.08)\end{array}$ & $\begin{array}{l}-0.08 \\
(0.07)\end{array}$ \\
\hline Santos 2014 & $\begin{array}{c}-0.57^{\text {*** }} \\
(0.02)\end{array}$ & $\begin{array}{c}-0.56^{* * *} \\
(0.02)\end{array}$ & $\begin{array}{c}-0.57^{* * *} \\
(0.02)\end{array}$ & $\begin{array}{c}-0.56^{* * *} \\
(0.02)\end{array}$ \\
\hline Violence Controls & No & Level & $\mathrm{PC}$ & Pop Density \\
\hline $\mathrm{N}$ & 911 & 911 & 911 & 911 \\
\hline Adjusted $\mathrm{R}^{2}$ & 0.68 & 0.69 & 0.70 & 0.68 \\
\hline Residual Std. Error & 9.05 & 8.87 & 8.68 & 9.01 \\
\hline F Statistic & $128.64^{* * *}$ & $73.46^{* * *}$ & $78.27^{* * *}$ & $70.24^{* * *}$ \\
\hline
\end{tabular}

To control for correlated political preferences in municipalities, results from the 2014 presidential election are included to proxy for pro-Santos preferences. The initial general election results are used instead of the two-candidate run-off to get a truer measure of preferences. The vote share in the primary with more than two candidates should be more representative of the political climate in a municipality than when the race has been reduced to a binary option. The Santos primary vote share was very negatively correlated with no no-vote share. This is not surprising because Santos was the face of the peace deal. If voter preferences were heavily determined by latent partisanship, and land 
ownership status was a determinant of party support, this may have led to biased results. ${ }^{13}$ The inclusion of this variable should cover the latent partisanship ${ }^{14}$ and allow the remaining variables to explain variations in voting beyond party lines. However, even with the inclusion of this political preferences variable, the landownership variables remain influential.

The semi-parametric estimates in Figure 1 suggest a strong nonlinear relationship of legal land ownership with vote outcomes, particularly at lower levels of titling per capita. To accommodate this nonlinearity, the land title variable is broken up into quintile dummy variables. These results are presented in Table 4. The results suggest after accounting for political preferences, the effects of the institutional transitional gains trap against the peace deal were most concentrated between 1 in 10 and 2 in 5 titles per head. Any omitted variable biasing these estimates would have to operate in a manner that would not be captured by either political preferences or income.

For further robustness, the municipal vote shares for President Uribe in 2006 is used as a control to control for latent political preferences in a converse manner from the Santos control. Uribe, who currently serves as a Senator, was the leader of the opposition to the peace deal. More importantly, Uribe made a military defeat of the insurgent actors in Colombia a priority of his tenure as president of Colombia, instituting a widespread security program in his first term that increased conflict. ${ }^{15}$ The inclusion of Uribe's re-election voting results should pick up some of the unobserved preferences for military conflict with FARC as it was a major campaign point. This is included in the appendix in Table 1.6. The land titling variables remain robust to the inclusion of this control.

\subsection{Discussion}

Economists have established that strong property rights, specifically land titling, are essential for economic growth and prosperity. On a more specific scale, lack of land registration has perverse effects

\footnotetext{
${ }^{13}$ This is only a problem if there is something unique about land ownership status that determines political preferences beyond the included demographic controls, particularly income, poverty rate, population, and rural population percentage.

${ }^{14}$ Presumably a voter would cast a ballot for Santos in 2014 if they supported the continuation of the peace negotiations, or another candidate if they did not.

${ }^{15}$ Uribe continued and intensified the aforementioned Plan Colombia as President.
} 
on an economy. Chen, 2017 models the effects of granting formal land titles and suggests that doing so would increase agricultural productivity by over 80 percent. Lack of land titles distorts agricultural resource allocations and labor decisions by farmers. Introduction of land titling removes this stickiness from these labor markets and increases migration De Janvry et al., 2015. The gains to land titling only make it more perplexing as to why these inefficient institutions remain. Understanding why is paramount to development efforts in the future.

Goldstein and Udry (2008) show in Ghana that land secure in ownership is more productive, but more interestingly that politically powerful people held stronger property rights. There is less incentive to invest in informally owned land, such as leaving it fallow, because the unused land is more susceptible to property rights transgressions. Formally owned parcels are more productive because investment is protected. The institutional transitional gains trap explains why formal owners would not want to extend property rights to protect a comparative advantage. The finding that formal land is more productive only deepens the difference in returns to formal land in a mixed system.

When an institutional conflict over property rights regimes arise growth will be hampered in the absence of a solution. The institutional transitional gains trap only becomes binding if private solutions cannot be used to reach a cooperative equilibrium. Private agreements to generate institutions can be efficient methods for establishing property rights without state actors, or in the absence of their action (Stringham, 2015). This has been observed in a multitude of different cultures (Benson, 1988; Benson and Siddiqui, 2014; Leeson, 2012, 2013). Private solutions to property rights disputes can also emerge among warring or violent factions (Leeson, 2007, 2009)as is the case in Colombia. However, individuals covered under informal institutions may prefer a formal institutional system in lieu of private methods if they fail to effectively adjudicate disputes. In Colombia in particular, the history of conflict and the persons it has displaced would make it difficult for non-public property rights institutions to reach a stable equilibrium, leaving many to turn to an immediate solution with formal institutions.

It is possible that omitted variables correlated with land ownership are driving the empirical 
results supporting the transitional gains trap. There are many reasons one might postulate as to why a Colombian voter would not support the peace deal just having been exposed to violence and a desire for greater retribution than that provided by the deal or land ownership. Considering the whole deal, it is easy to believe that a lack of trust in the Colombian government would also drive dissension. If voters do not trust the government then it does not matter which part of the deal they are considering if they believe nothing will actually change. There is survey-based evidence from Afghanistan and neighboring Peru that informal owners do not want property rights from the government because local private property rights methods may be more preferred (Kerekes and Williamson, 2010; Murtazashvili and Murtazashvili, 2015). However, Colombia has much more developed public institutions than Afghanistan and Peru has significantly higher levels of distrust in the Government, scoring a -55 on the World Value Survey (World Values Survey Association, 2010-2014). Colombia scores higher on trust than nearby Chile or Argentina, making it third regionally, and higher than the United States or Australia. Unfortunately, this data is not available at a sub-national level, but Colombia's relative performance casts doubt on the claim that lack of trust caused the no vote.

When examining only the property rights reform measure of the deal, one could argue that Colombians do not trust the government to enforce property rights. However, in areas that already have property rights, either entirely or some, Colombia scores quite well, with a 9.43 physical property sub-index (Levy-Carciente, 2017). That is nearly a perfect score. Additionally, wealthier people in Colombia have higher levels of trust in government (World Values Survey Association, 2010-2014), and the wealthy are disproportionately the target of FARC kidnapping and ransom so they have a lot to gain from the passage of the deal. Fighting wars is expensive and the wealthy may be subjected to higher taxes or fewer benefits by continuing the war.

The transitional gains trap applied to property rights institutions has a similar logic to the home voter hypothesis (Fischel, 2001). The approach in this paper is similar to the empirical work on the home voter hypothesis, looking at voter preferences and school vouchers (Brunner, Sonstelie, and Thayer, 2001) and stadium subsidies (Dehring, Depken, and Ward, 2008). The home voter literature has focused on public goods in localized referenda using data from the US or Europe. This paper 
expands on this research by using a national event in a non-Western country and extending the concept to institutions, not just local public goods. This application of the home voter hypothesis with the transitional gains trap to property rights institutions broadens the scope beyond public and urban economics to contribute to both the institutional and development literature. Because the event studied here involves individual voters' incentives in a democratic process, the empirical analysis is similar to the work on the home voter hypothesis. But it is important to think of the institutional transitional gains trap as disparate from home voting. The logic of the institutional transitional gains trap is not confined to democratic systems or a one-period referendum.

\subsection{Conclusion}

The effects of the Colombian conflict have been long felt in the region. Ironically, property rights issues are one of the original causes of the civil war and have prevented peace from being established and ending the conflict. The empirical evidence here supports the hypothesis that potential decreases in property values drove landowners' voting preferences against the peace deal and to prevent the extension of property rights enfranchisement. On average across Colombia, 1 percent more legal land ownership increases distension for a peace deal where the most feasible term is property reform by approximately 3 percent. In areas where legal ownership is low, the marginal effect of ownership on preferences against the deal is stronger. These results are suggestive of the institutional transitional gains trap hampering development.

Property rights are arguably the most important institution to economic prosperity. Economists have established this, but the literature lacks understanding as to why poor property rights are difficult to fix in a time where technological advances should make this seamless. However, when the institution is applied unequally it creates fissures, which can lead to civil war in the case of Colombia, and which are very hard to mend. Fixing unequal property rights can become increasingly complicated when they fall into this transitional gains trap. The evidence from the referendum voting results supports this theory, with high support being given from informal owners and low support 
from legal owners. However, the empirical evidence here is limited by cross-sectional voting results at municipal levels to proxy for individual preferences. This effect is worthy of further study, and intriguing and more compelling opportunities for research exist beyond Colombia. Individual level data including informal land transactions and a multitude of possible field studies are necessary to fully understand the lack of dynamic institutional reform.

If the transitional gains trap is hampering property rights enfranchisement, the implications for institutional reform is clear. Reforms must be undertaken before the median voter is a legal title holder if they are going through a democratic process. The potential for reform may never come about if the median voter is a legal property holder. This creates a much more difficult situation for fixing corrupted institutions. Thus, the relevant policy question becomes how to design Pareto efficient mechanisms for formalizing property that are acceptable to current legal landowners. Perhaps in places that remain saddled with dead capital, property tax subsidies could be provided to current title holders to compensate their capitalized loss and allow for the transition of informal property. The lessons from Colombia should be considered to prevent property rights reforms elsewhere from falling victim to the institutional transitional gains trap.

\subsection{Appendix}


Table 1.5: Appendix Table 1

\begin{tabular}{lcccc}
\hline \hline Statistic & Mean & St. Dev. & Min & Max \\
\hline FARC Subversive Actions & 1.853 & 5.489 & 0 & 63 \\
FARC Property Assault & 0.481 & 1.376 & 0 & 19 \\
FARC Entity Attack & 0.562 & 1.348 & 0 & 12 \\
FARC Killed Soldiers & 0.373 & 1.073 & 0 & 11 \\
FARC Checkpoint & 0.098 & 0.670 & 0 & 18 \\
FARC Armed Contact & 9.808 & 22.323 & 0 & 315 \\
FARC Ambushes & 0.649 & 1.716 & 0 & 21 \\
FARC Engagements & 0.331 & 1.114 & 0 & 12 \\
FARC Homicides & 1.732 & 4.091 & 0 & 59 \\
FARC Political Homicide & 0.168 & 0.593 & 0 & 9 \\
FARC Hostages & 0.655 & 2.994 & 0 & 47 \\
FARC Incursions & 0.221 & 0.589 & 0 & 5 \\
FARC Land piracy & 0.826 & 2.122 & 0 & 30 \\
\hline
\end{tabular}


Table 1.6: Appendix Table 2

\begin{tabular}{|c|c|c|c|c|c|c|c|c|c|}
\hline & $\begin{array}{l}\text { Percent No } \\
\text { (1) }\end{array}$ & $\begin{array}{c}\text { No Turnout } \\
(2)\end{array}$ & $\begin{array}{c}\text { Total Turnout } \\
\text { (3) }\end{array}$ & $\begin{array}{c}\text { Percent No } \\
(4)\end{array}$ & $\begin{array}{c}\text { No Turnout } \\
(5)\end{array}$ & $\begin{array}{c}\text { Total Turnout } \\
\text { (6) }\end{array}$ & $\begin{array}{c}\text { Percent No } \\
(7)\end{array}$ & $\begin{array}{c}\text { No Turnout } \\
(8)\end{array}$ & $\begin{array}{c}\text { Total Turnout } \\
\text { (9) }\end{array}$ \\
\hline (log)Legal Titles & $\begin{array}{l}1.83^{* *} \\
(0.91)\end{array}$ & $\begin{array}{c}1.05^{* * *} \\
(0.27)\end{array}$ & $\begin{array}{l}0.95^{* *} \\
(0.45)\end{array}$ & $\begin{array}{l}1.53^{*} \\
(0.90)\end{array}$ & $\begin{array}{c}0.91^{* * *} \\
(0.27)\end{array}$ & $\begin{array}{l}0.84^{*} \\
(0.46)\end{array}$ & $\begin{array}{l}1.64^{*} \\
(0.93)\end{array}$ & $\begin{array}{c}0.90^{* * *} \\
(0.27)\end{array}$ & $\begin{array}{l}0.82^{*} \\
(0.46)\end{array}$ \\
\hline (log)Property Size & $\begin{array}{c}1.77^{* * *} \\
(0.55)\end{array}$ & $\begin{array}{c}0.86^{* * *} \\
(0.24)\end{array}$ & $\begin{array}{c}0.20 \\
(0.29)\end{array}$ & $\begin{array}{c}1.79^{* * *} \\
(0.56)\end{array}$ & $\begin{array}{c}0.84^{* * *} \\
(0.25)\end{array}$ & $\begin{array}{c}0.13 \\
(0.29)\end{array}$ & $\begin{array}{l}1.41^{* *} \\
(0.57)\end{array}$ & $\begin{array}{c}0.74^{* * *} \\
(0.25)\end{array}$ & $\begin{array}{c}0.28 \\
(0.29)\end{array}$ \\
\hline Informal Land & $\begin{array}{c}-0.16^{* * *} \\
(0.03)\end{array}$ & $\begin{array}{c}-0.03^{* *} \\
(0.01)\end{array}$ & $\begin{array}{c}0.05^{* * *} \\
(0.02)\end{array}$ & $\begin{array}{c}-0.14^{* * *} \\
(0.03)\end{array}$ & $\begin{array}{l}-0.02 \\
(0.01)\end{array}$ & $\begin{array}{c}0.05^{* * *} \\
(0.02)\end{array}$ & $\begin{array}{c}-0.15^{* * *} \\
(0.03)\end{array}$ & $\begin{array}{l}-0.02 \\
(0.01)\end{array}$ & $\begin{array}{c}0.06^{* * *} \\
(0.02)\end{array}$ \\
\hline Uribe '06 & $\begin{array}{c}0.36^{* * *} \\
(0.03)\end{array}$ & $\begin{array}{c}0.13^{* * *} \\
(0.01)\end{array}$ & $\begin{array}{l}0.003 \\
(0.01)\end{array}$ & $\begin{array}{c}0.36^{* * *} \\
(0.03)\end{array}$ & $\begin{array}{c}0.13^{* * *} \\
(0.01)\end{array}$ & $\begin{array}{l}0.001 \\
(0.01)\end{array}$ & $\begin{array}{c}0.36^{* * *} \\
(0.03)\end{array}$ & $\begin{array}{c}0.14^{* * *} \\
(0.01)\end{array}$ & $\begin{array}{c}0.01 \\
(0.01)\end{array}$ \\
\hline FARC presence & $\begin{array}{c}0.52^{* * *} \\
(0.10)\end{array}$ & $\begin{array}{c}0.21^{* * *} \\
(0.05)\end{array}$ & $\begin{array}{c}0.14^{* * *} \\
(0.05)\end{array}$ & $\begin{array}{c}0.47^{* * *} \\
(0.09)\end{array}$ & $\begin{array}{c}0.20^{* * *} \\
(0.04)\end{array}$ & $\begin{array}{l}0.13^{* *} \\
(0.06)\end{array}$ & $\begin{array}{c}0.38^{* * *} \\
(0.09)\end{array}$ & $\begin{array}{c}0.15^{* * *} \\
(0.04)\end{array}$ & $\begin{array}{l}0.11^{* *} \\
(0.05)\end{array}$ \\
\hline $\begin{array}{l}\text { FARC Violence Controls } \\
\text { FARC Violence Per Capita }\end{array}$ & $\mathrm{Y}$ & $\mathrm{Y}$ & $\mathrm{Y}$ & & & & & & \\
\hline $\begin{array}{l}\text { FARC Violence Per Capita } \\
\text { FARC Violence (Pop Density) }\end{array}$ & & & & $\mathrm{Y}$ & $\mathrm{Y}$ & $\mathrm{Y}$ & $Y$ & $Y$ & $Y$ \\
\hline Demographic Controls & $\mathrm{Y}$ & Y & Y & $\mathrm{Y}$ & Y & $\mathrm{Y}$ & $\mathrm{Y}$ & Y & Y \\
\hline Constant & $\mathrm{Y}$ & $\mathrm{Y}$ & $\mathrm{Y}$ & $\mathrm{Y}$ & $\mathrm{Y}$ & $\mathrm{Y}$ & $\mathrm{Y}$ & $\mathrm{Y}$ & $\mathrm{Y}$ \\
\hline $\mathrm{N}$ & 912 & 912 & 912 & 912 & 912 & 912 & 912 & 912 & 912 \\
\hline Adjusted $\mathrm{R}^{2}$ & 0.51 & 0.53 & 0.35 & 0.51 & 0.54 & 0.35 & 0.50 & 0.53 & 0.35 \\
\hline Residual Std. Error & 11.13 & 5.20 & 6.29 & 11.10 & 5.17 & 6.28 & 11.23 & 5.22 & 6.25 \\
\hline F Statistic & $36.36^{* * *}$ & $39.48^{* * *}$ & $18.87^{* * *}$ & $36.81^{* * *}$ & $40.25^{* * *}$ & $18.97^{* * *}$ & $35.17^{* * *}$ & $38.95^{* * *}$ & $19.43^{* * *}$ \\
\hline
\end{tabular}

${ }^{*} \mathrm{p}<.1 ;{ }^{* *} \mathrm{p}<.05 ;{ }^{* * *} \mathrm{p}<.01$
${ }^{*}$ Heteroskedasticity robust standard errors

* Violence controls include all reported private property attacks, soldiers killed, checkpoints, ambushes, engagements, homicides, political homicides, hostages taken, incursions, and land piracy committed by FARC. * Demographic controls are GDP per capita, agriculture share of GDP, (log)Population, rural population, distance to market, and poverty rate. 
Table 1.7: Appendix Table 3

\begin{tabular}{|c|c|c|c|c|c|c|c|c|c|c|}
\hline & \multicolumn{2}{|c|}{ Percent No } & \multirow{2}{*}{$\begin{array}{c}\text { No Turnout } \\
(3)\end{array}$} & \multirow{2}{*}{$\begin{array}{c}\text { Total Turnout } \\
\text { (4) }\end{array}$} & \multirow{2}{*}{$\begin{array}{c}\text { Percent No } \\
(5)\end{array}$} & \multirow{2}{*}{$\begin{array}{c}\text { No Turnout } \\
(6)\end{array}$} & \multirow{2}{*}{$\begin{array}{l}\text { Total Turnout } \\
\quad(7)\end{array}$} & \multirow{2}{*}{$\begin{array}{c}\text { Percent No } \\
(8)\end{array}$} & \multirow{2}{*}{$\begin{array}{c}\text { No Turnout } \\
(9)\end{array}$} & \multirow{2}{*}{$\begin{array}{c}\text { Total Turnout } \\
\quad(10)\end{array}$} \\
\hline & (1) & (2) & & & & & & & & \\
\hline log Population & $-2.39^{* * *}$ & $-1.98^{* *}$ & $-1.22^{* * *}$ & $-1.66^{* * *}$ & $-2.32^{* * *}$ & $-1.36^{* * *}$ & $-1.53^{* * *}$ & $-1.92^{* *}$ & $-1.16^{* * *}$ & $-1.65^{* * *}$ \\
\hline & $(0.76)$ & $(0.77)$ & $(0.26)$ & $(0.37)$ & $(0.74)$ & $(0.26)$ & $(0.38)$ & $(0.89)$ & $(0.27)$ & $(0.40)$ \\
\hline Distance to market & $-0.03^{* * *}$ & $\begin{array}{l}-0.03^{* * *} \\
(0.01)\end{array}$ & $-0.01^{* * * *}$ & $\begin{array}{l}-0.001 \\
(0.003)\end{array}$ & $-0.03^{* * *}$ & $\begin{array}{l}-0.01^{* * *} \\
(0.003)\end{array}$ & $\begin{array}{l}-0.001 \\
(0.003)\end{array}$ & $\begin{array}{l}-0.03^{* * *} \\
(0.01)\end{array}$ & $\begin{array}{l}-0.01^{* * *} \\
(0.003)\end{array}$ & $\begin{array}{l}-0.0004 \\
(0.003)\end{array}$ \\
\hline Rural pct & 0.06 & $0.07^{*}$ & $0.03^{* *}$ & 0.02 & 0.06 & $0.03^{* *}$ & 0.02 & 0.05 & $0.03^{* *}$ & 0.03 \\
\hline & $(0.04)$ & & $(0.01)$ & & & $(0.01)$ & $(0.02)$ & $(0.04)$ & $(0.01)$ & $(0.02)$ \\
\hline Poverty rate & $\begin{array}{c}-0.32^{* * * *} \\
(0.04)\end{array}$ & $\begin{array}{c}-0.28^{* * * *} \\
(0.04)\end{array}$ & $\begin{array}{c}-0.24^{* * *} \\
(0.02)\end{array}$ & $\begin{array}{c}-0.31^{* * *} \\
(0.02)\end{array}$ & $\begin{array}{c}-0.27^{* * *} \\
(0.04)\end{array}$ & $-0.24^{* * *}$ & $-0.31^{* * * *}$ & $-0.31^{* * * *}$ & $-0.26^{* * * *}$ & $-0.33^{* * * *}$ \\
\hline GDP PC & $0.29^{* * * *}$ & $0.24^{* *}$ & $0.10^{* *}$ & 0.01 & $0.26^{* * *}$ & $0.11^{* * * *}$ & $\begin{array}{c}(0.02) \\
0.02\end{array}$ & $\begin{array}{l}(0.04) * \\
0.27^{* * *}\end{array}$ & $\begin{array}{l}(0.02) \\
0.11^{* *}\end{array}$ & $\begin{array}{l}(0.02) \\
0.022\end{array}$ \\
\hline & $(0.10)$ & $(0.10)$ & $(0.04)$ & $(0.04)$ & $(0.10)$ & $(0.04)$ & $(0.04)$ & $(0.10)$ & $(0.04)$ & $(0.04)$ \\
\hline Ag pct GDP & 0.82 & 0.81 & $2.49^{*}$ & $3.66^{* * *}$ & 2.20 & $3.16^{* *}$ & $4.15^{* * *}$ & 0.62 & $2.44^{*}$ & 3. $71^{* * * *}$ \\
\hline & $(2.92)$ & $(2.87)$ & $(1.31)$ & $(1.39)$ & $(2.82)$ & $(1.30)$ & $(1.41)$ & $(2.92)$ & $(1.33)$ & $(1.39)$ \\
\hline Coca Production & -1.68 & 3.07 & 0.01 & -1.82 & 2.58 & -0.03 & -1.84 & -1.01 & -1.24 & $\begin{array}{l}-1.39 \\
\end{array}$ \\
\hline Terrorism & $(2.95)$ & $(2.98)$ & $(1.23)$ & $(1.39)$ & $(2.91) *$ & $(1.17)$ & $(1.33)$ & $(2.95)$ & $(1.16)$ & $(1.27)$ \\
\hline Terrorism & & $\begin{array}{l}-0.01 \\
(0.004)\end{array}$ & $\begin{array}{l}-0.0005 \\
(0.002)\end{array}$ & $\begin{array}{l}0.01 \% 1 \\
(0.002)\end{array}$ & $\begin{array}{l}-0.14^{*} \\
(0.08)\end{array}$ & $\begin{array}{l}-0.01 \\
(0.02)\end{array}$ & $\begin{array}{l}0.1005 \\
(0.05)\end{array}$ & $\begin{array}{l}-0.002 \\
(0.01)\end{array}$ & $\begin{array}{l}0.003 \\
(0.003)\end{array}$ & $\begin{array}{l}0.01 * x \\
(0.003)\end{array}$ \\
\hline Abductions & & 0.02 & $0.01^{* * *}$ & $0.01^{*}$ & 0.12 & 0.11 & $0.28^{* * *}$ & 0.02 & 0.01 & 0.004 \\
\hline & & $(0.02)$ & $(0.01)$ & $(0.01)$ & $(0.25)$ & $(0.10)$ & $(0.08)$ & $(0.01)$ & $(0.01)$ & $(0.01)$ \\
\hline Torture & & $\begin{array}{l}-0.04 \\
(0.03)\end{array}$ & -0.01 & 0.01 & 0.02 & 0.05 & -0.01 & -0.09 & -0.02 & 0.03 \\
\hline Land theft & & $\begin{array}{c}(0.03) * \\
-0.01 * * *\end{array}$ & $\begin{array}{l}(0.01) \\
-0.001\end{array}$ & $\begin{array}{l}(0.02) \\
0.002^{*}\end{array}$ & $\begin{array}{l}(0.42) \\
-0.10^{* * *}\end{array}$ & $\begin{array}{l}(0.19) \\
-0.02\end{array}$ & $\begin{array}{c}(0.36) \\
0.03\end{array}$ & $\begin{array}{l}(0.06) \\
-0.003\end{array}$ & $\begin{array}{l}(0.02) \\
-0.001\end{array}$ & $\begin{array}{c}(0.03) \\
-0.0002\end{array}$ \\
\hline & & $(0.002)$ & $(0.001)$ & $(0.001)$ & $(0.04)$ & $(0.02)$ & $(0.03)$ & $(0.002)$ & $(0.001)$ & $(0.001)$ \\
\hline Landmines & & $\begin{array}{l}-0.08^{* * *} \\
(0.02)\end{array}$ & $\begin{array}{l}-0.03^{* * *} \\
(0.01)\end{array}$ & $\begin{array}{l}-0.01 \\
(0.01)\end{array}$ & $\begin{array}{l}-1.83^{* * *} \\
(0.51)\end{array}$ & $\begin{array}{l}-0.75^{* * *} \\
(0.23)\end{array}$ & $\begin{array}{l}-0.003 \\
(0.25)\end{array}$ & $\begin{array}{l}-0.11^{* * *} \\
(0.04)\end{array}$ & $\begin{array}{c}-0.05^{* * *} \\
(0.02)\end{array}$ & $\begin{array}{l}-0.02 \\
(0.02)\end{array}$ \\
\hline Child soldiers & & 0.04 & 0.02 & 0.005 & 0.91 & 0.72 & 0.83 & 0.01 & 0.02 & $\begin{array}{c}0.03 \\
0.03\end{array}$ \\
\hline & & $(0.07)$ & $(0.03)$ & $(0.04)$ & $(1.31)$ & $(0.56)$ & $(0.69)$ & $(0.04)$ & $(0.02)$ & $\begin{array}{l}0.03 \\
(0.02)\end{array}$ \\
\hline Homicides & & 0.001 & -0.0003 & -0.001 & $0.07^{* * *}$ & 0.01 & -0.01 & -0.0000 & 0.0001 & 0.0001 \\
\hline & & & $(0.0005)$ & $(0.001)$ & $(0.04)$ & $(0.02)$ & $(0.02) *$ & $(0.0003)$ & $(0.0001)$ & $(0.0001)$ \\
\hline Displaced & & $\begin{array}{l}-0.0001 \\
(0.0001)\end{array}$ & $\begin{array}{c}-0.0001 \\
(0.00)\end{array}$ & $\begin{array}{l}-0.00 \\
(0.00)\end{array}$ & $\begin{array}{c}-0.011+2 \pi \\
(0.002)\end{array}$ & $\begin{array}{c}-0.004^{* 7 *} \\
(0.001)\end{array}$ & $\begin{array}{c}-0.003^{* *} \\
(0.001)\end{array}$ & $\begin{array}{l}-0.00 \\
(0.0001)\end{array}$ & $\begin{array}{l}-0.00 \\
(0.00)\end{array}$ & $\begin{array}{l}0.00 \\
(0.00)\end{array}$ \\
\hline Forced Disappearance & & 0.01 & $0.004^{* * *}$ & 0.003 & -0.02 & 0.03 & 0.04 & 0.001 & 0.0001 & -0.001 \\
\hline & & $(0.004)$ & $(0.002) *$ & $(0.002)$ & $(0.11)$ & $(0.05)$ & $(0.07)$ & $(0.002)$ & $(0.001)$ & $(0.001)$ \\
\hline Sex crimes & & $\begin{array}{l}-0.06^{* * *} \\
(0.02)\end{array}$ & $\begin{array}{l}-0.04^{* * *} \\
(0.01)\end{array}$ & $\begin{array}{l}-0.03 \\
(0.02)\end{array}$ & $\begin{array}{l}-0.80 \\
(0.54)\end{array}$ & $\begin{array}{l}-0.25 \\
(0.26)\end{array}$ & $\begin{array}{l}0.24 \\
(0.55)\end{array}$ & $\begin{array}{l}-0.02 \\
(0.03)\end{array}$ & $\begin{array}{c}-0.03^{* *} \\
(0.01)\end{array}$ & $\begin{array}{c}-0.05^{* *} \\
(0.02)\end{array}$ \\
\hline Threats & & 0.002 & 0.0005 & -0.001 & 0.04 & 0.001 & $-0.03^{*}$ & 0.001 & $\begin{array}{l}(0.001) \\
0.0002\end{array}$ & -0.0004 \\
\hline & & $(0.002)$ & $(0.001)$ & $(0.001)$ & $(0.03)$ & $(0.01)$ & $(0.02)$ & $(0.001)$ & $(0.001)$ & $(0.0005)$ \\
\hline Forced land abandon & & -0.004 & -0.003 & -0.0001 & 0.08 & 0.06 & 0.10 & 0.002 & -0.001 & -0.004 \\
\hline & & $(0.01)$ & $(0.002)$ & $(0.003)$ & $(0.15)$ & $(0.06)$ & $(0.07)$ & $(0.004)$ & $(0.002)$ & $(0.003)$ \\
\hline Defensive actions & & $\begin{array}{l}-0.002 \\
(0.004)\end{array}$ & $\begin{array}{l}-0.001 \\
(0.002)\end{array}$ & $\begin{array}{l}0.001 \\
(0.002)\end{array}$ & $\begin{array}{l}0.32^{2 *} \\
(0.15)\end{array}$ & $\begin{array}{l}0.14^{* *} \\
0.066\end{array}$ & $\begin{array}{l}0.06 \\
(0.08)\end{array}$ & -0.0003 & $\begin{array}{l}-0.0004 \\
(0.0004)\end{array}$ & $\begin{array}{l}-0.001^{*} \\
(0.0004)\end{array}$ \\
\hline $\mathrm{N}$ & 914 & $\begin{array}{l}(0.004) \\
914\end{array}$ & $\begin{array}{l}(0.002) \\
914\end{array}$ & $\begin{array}{l}(0.002) \\
914\end{array}$ & $\begin{array}{l}(0.15) \\
914\end{array}$ & $\begin{array}{l}(0.06) \\
914\end{array}$ & $\begin{array}{l}(0.08) \\
914\end{array}$ & $\begin{array}{c}(0.001) \\
914\end{array}$ & $\begin{array}{l}(0.0004) \\
914\end{array}$ & $\begin{array}{l}(0.0004) \\
914\end{array}$ \\
\hline Adjusted $\mathrm{R}^{2}$ & & $\begin{array}{l}914 \\
0.38\end{array}$ & & $\begin{array}{l}914 \\
0.37\end{array}$ & $\begin{array}{l}914 \\
0.39\end{array}$ & $\begin{array}{l}914 \\
0.46\end{array}$ & $\begin{array}{l}914 \\
0.37\end{array}$ & 0.35 & 0.44 & 0.37 \\
\hline Residual Std. Error & $\begin{array}{l}0.34 \\
12.91\end{array}$ & $\begin{array}{l}0.38 \\
12.50\end{array}$ & $\begin{array}{l}0.46 \\
5.59\end{array}$ & $\begin{array}{l}0.37 \\
6.19\end{array}$ & $\begin{array}{r}0.39 \\
12.43\end{array}$ & $\begin{array}{l}0.46 \\
5.58\end{array}$ & 6.18 & $\begin{array}{l}0.35 \\
12.82\end{array}$ & $\begin{array}{l}0.44 \\
5.67\end{array}$ & 6.17 \\
\hline F Statistic & $44.25^{* * * *}$ & $24.74^{* * *}$ & $33.23^{* * *}$ & $23.08^{* * * *}$ & $25.36^{* * * *}$ & $33.44^{* * * *}$ & $23.29^{\circ * *}$ & $21.70^{* * * *}$ & $31.22^{* * *}$ & $23.39^{* * *}$ \\
\hline
\end{tabular}

${ }_{*}^{*} \mathrm{p}<.1 ; * * \mathrm{p}<.05 ; * * * \mathrm{p}<.01$

* Heteroskedasticity robust standard errors
Models 2-4 uses level violence controls, 5-7 uses population adjusted violence controls, and 8-10 uses population density adjusted violence controls. 


\section{Chapter 2}

\section{Knowledge is Powder: Effect of Forecasting Services in Natural Hazard Management}

\section{$2.1 \quad$ Introduction}

Taking on risk is a necessary part of everyday life. Traveling anywhere requires individuals to subsume the underlying risks associated with their chosen method of travel. It is natural for people to want to minimize the risk they are exposed to, but this risk may be part of the enjoyment of the activity. Sometimes individuals do not utilize options available to them to decrease the risks they are undertaking, like not wearing a seat belt in an automobile or riding a motorcycle without a helmet. Policies often rely on coercion to incentivize individuals to decrease the amount of risk they undertake in a given activity, such as mandatory seat belt and helmet laws in the aforementioned cases. While coercive sanctions are often justified because negative externalities emanate from the risky behavior in question, such as drunk driving or maternal substance abuse, they are also used in cases where the negative externalities are minimal to non-existent. Motorcycle helmet laws are a prime example, where the additional risk from riding a motorcycle without a helmet does not spill over to other individuals.

Other policy options exist beyond coercion to incentivize optimal risk taking behavior. Instead of 
some negative incentive, sometimes programs as simple as providing individuals more information about the relevant risky behavior can discourage undue risk taking. For example, extensive public heath campaigns to inform smokers about the long-term health consequences of smoking aided in reducing smoking rates in Western countries. Often these policies are implemented together introducing negative incentives as well as increasing efforts to better inform individuals about the risk. Purely informational campaigns are seldom used to influence risk taking behavior. An example from one extreme is the "click-it or ticket' campaign to increase seat belt use in the United States (Luca, 2015). This public ad campaign eschews informing motorists of the potential additional bodily harm from not wearing a seat belt and instead informs motorists of police issued fines for non-compliance. In this paper I investigate the extent to which information alone impacts outcomes from risk taking behavior, using a unique setting free from negative incentives, avalanche hazard management in winter backcountry recreation.

The culture in alpine recreation is that a backcountry user is free to choose the level of risk she finds acceptable. ${ }^{1}$ Access on public lands is not restricted due to avalanche danger. Private investments in avalanche safety are not mandatory. You can receive nothing more than a verbal scolding from a Forest Service Ranger for venturing into avalanche terrain on public land without adequate equipment, training, or information. This tradition allows me to add to the literature on modifying risky behaviors in a manner that has been under-explored because negative incentives are so often favored by policy makers.

Little is known about the exact number of people traveling in avalanche terrain, but proxies for usage such as gear sales and use permits all point to exponential increases across previous decades. This growth in usage is not reflected in fatalities, however. Reported avalanche fatalities have remained stable in both the US and Canada over the past 20 years, not appearing to increase with the number of people venturing into avalanche terrain (Avalanche Canada, 2019; Logan and Witmer, 2012). Similar trends in decreasing incident rates are also documented in Europe (Techel et al., 2016). So what explains these diverging trends? This paper identifies what role extended avalanche

\footnotetext{
${ }^{1}$ I only know of once instance where negative incentives have been used to modify behavior of backcountry users, when a mayor in France instituted a fine for people attempting to climb Mount Blanc without 'proper equipment' (Willsher, 2017).
} 
forecasting services have played in reducing observed avalanche incidents using policy changes by state avalanche centers.

Backcountry recreators use information provided by a local avalanche center, where avalanche forecasters publish a daily bulletin during peak season with danger ratings and information about the main avalanche problems of concern. Forecasters create the daily bulletin based on weather, experience, and observations from the field, which are provided by professional avalanche observers and backcountry users. Individuals then considering travel in or around avalanche terrain can use these forecasts to make terrain and route choices around the reported hazard levels. One would expect that individuals with better information sets will make better choices. For example, when provided with more information about compounding interest, individuals reduce their use of 'pay-day lending' services and smokers are more likely to attempt to quit when shown pictures of harmful effects of smoking in addition to the Surgeon General's warning (Bertrand and Morse, 2011; Brewer et al., 2016).

There are a number of ways reduced uncertainty could license more risk taking behavior or may lead to observing more incidents. If uncertainty about the underlying risk deters people from engaging in a risky activity, then more information might lead to more incidents by increasing the number of people entering avalanche terrain. For example, news informing people of road plowing in winter weather conditions might elicit risk averse types to travel who would not have otherwise without seeing cleared roads and snow plows on the news. Additional information may also increase observed incidents along the extensive margin, licensing less risk averse types to take on more risk. Clark and Lee (1997) argue that increased rescue services on Denali lead to more accidents among mountaineers.

Avalanche forecasting services could have a null effect on incidents and the relative decline in avalanche fatalities could be attributed to other measures such as private investments in safety equipment and training. Avalanche transceivers ${ }^{2}$ have become easier to use, airbag backpacks have come on the market, and increasing numbers of people are taking avalanche safety courses (Stuart,

\footnotetext{
${ }^{2}$ Beacons used to locate victims buried in an avalanche
} 
2017). Information intended to modify behavior may not have the intended effect, and observed changes may be attributable to other prevailing trends (Anderson, 2010). The underlying avalanche risk is constantly changing which could lead to displacement effects intratemporally between regions and intertemporally between days that offset gains in safety by publicizing higher danger levels.

Identifying the impact of the forecast and information on outcomes in the backcountry requires careful examination of observational data. A randomized control trial with the forecaster products is not possible for obvious reasons. Additionally, simply regressing outcomes on forecaster operations is rife with endogeneity because forecasters operate when the underlying danger level is highest. To net out the impact of daily forecasts, I exploit policy changes in the 2018-19 season that required the Colorado forecasting office to remain open at full capacity two weeks longer than normal, and continue to operate on a daily but reduced capacity for four weeks beyond that. Zones in Utah are used as a control group. The main outcomes of interest is incidents when a backcountry traveler reports unintentionally triggering an avalanche. This includes reports from skiers, snowboarders, snowmobilers, as well as alpine climbers and hikers.

The result from a difference in difference specification with a season extension in Colorado shows that additional forecasting services reduce reported incidents on considerable danger days, the highest danger level prescribed in the treatment period. Estimates show that reported incidents decreased 42 percent on considerable danger days. This would translate to the program extension in Colorado preventing around 1 incident a week. The effects are not monotonic, and modest increases in incidents occur on low danger days. This could occur from backcountry users substituting travel from considerable to low danger days, or from backcountry users selecting more avalanche prone terrain when provided with a forecast showing low danger. The aggregated nature of the data available does not allow me to differentiate between these mechanisms. 


\subsection{Background}

This paper lies in the intersection of two broader inquiries in economics, regulating and incentivizing safer behavior and natural hazard management. Reducing accidental deaths has been a large public investment and major policy campaign in previous centuries in the workplace, home, roadways, and recreation areas. Other natural hazards like floods or wildfires, and the human response to them, have received an extensive treatment in the economics literature (Bradshaw and Lueck, 2012; Michel-Kerjan, 2010). Avalanches as a natural hazard have largely remained absent the eyes of economic imperialism.

Avalanche hazard management is broadly conducted under two separate methods, humans modifying the environment or educating the human about the environment. The former is probably the most familiar to a layperson, where techniques are used to intentionally trigger avalanches to keep them small in size or remove hazards around human activity. There are many parallels in avalanche management to wildfire suppression methods (Lueck, 2012). Similar to forest fuel management practices, methods are used to divert avalanche hazards. Examples include snow fences to protect towns below slide paths and avalanche sheds to prevent roads and rail lines from being covered by avalanche debris. Also, just as prescribed burns are used to limit forest fire risks, avalanches may be triggered to reduce human risk, which is a common practice by Departments of Transportation (DOT) and ski resorts.

Avalanches can cause closures and endanger travelers caught on roadways that pass below avalanche terrain. To limit danger and shorten road closures from avalanche debris removal, DOT professionals will use a variety of explosive ordinances to control avalanche terrain. This is similar to wildfire management practices where prescribed fires are used to reduce wildfire risk. Unlike prescribed fires where legal liability can constrain its use (Yoder, 2008), avalanches have a defined path and crews can close roads or warn potential travelers of mitigation work. The main constraint on avalanche control is cost or danger. Methods like using helicopters to drop explosives or installing permanent systems to deploy charges can be expensive. Options that come with less monetary cost 
may bring higher risk, like using military artillery, ${ }^{3}$ or sending people to deploy charges exposing them in avalanche terrain.

\subsubsection{History}

Avalanche forecasting in the United States (and arguably recreation in the alpine) started with the return of 10th Mountain Division soldiers from WWII. Monty Atwater, a 10th Mountain veteran began avalanche mitigation outside of Salt Lake City, UT in Little Cottonwood Canyon in the 1940s. There he pioneered the use of explosives and military artillery to purposefully trigger slides (Atwater, 1968). For several decades, avalanche work focused on mitigation in specific slide paths or passes to keep highway corridors, ski areas, and industry in the alpine open.

Ski resorts in the American west often have avalanche terrain inside the resort boundaries which is managed by the ski patrol. Part of the services provided by ski areas is reducing avalanche risks, in addition to a lift up the mountain. Ski areas use control methods to make their in-bounds terrain safe for customers. ${ }^{4}$ Patrolers will conduct avalanche control before the resort opens to minimize avalanche risk or close off terrain when they deem it necessary.

Most avalanche terrain is not controlled, beyond the bounds of ski resorts or the concern of DOTs. It is not absent human travel, however, and practices to navigate this hazardous terrain developed throughout the 20th century. Formal avalanche forecasting began in Switzerland between the world wars(Origins of the avalanche bulletin - history and background). Avalanches during battles in the alpine during World War One added to the hazards of war. The Swiss military started training units on avalanche safety and advising them on current danger levels. This operation eventually morphed into the Swiss Institute for Snow and Avalanche Research, which began issuing bulletins for non-military users. The Swiss center has one central office which provides bulletins for zones covering the whole country. This centralized model would later influence the formation of avalanche centers in

\footnotetext{
${ }^{3}$ In 2005, Utah DOT overshot their intended target resulting in an artillery shell landing in a family's backyard.

${ }^{4}$ While they try to make the avalanche risk zero, it is not always the case. Recently in 2019 two skiers were killed in an in-bounds avalanche in New Mexico and the Colorado Supreme Court has ruled that avalanches are an inherent risk of in-bounds skiing(Colorado Supreme Court, 2016; Romero and Fieldstadt, 2019).
} 
North America. The first program in the US focused on advising backcountry recreationists started in 1973 with the US Forest Service's Colorado Avalanche Warning Program (Williams, 1998).

\subsubsection{Forecasting Process}

Forecasters produce a daily advisory bulletin to advise backcountry travelers of the avalanche danger in the backcountry. Though the avalanche advisory has much more nuance, it is similar in spirit to the Smokey Bear campaign by the Forest Service to warn people of wildfire hazards and encourage safe practices. A sample advisory is included in the appendix, see 2.11. Forecasters in North America use some variant of the 'Conceptual Model of Avalanche Hazard' to arrive at the daily bulletin (Statham et al., 2010). They will attribute a danger level to various aspects and elevations based on the danger scale, just like the 5 level system the US Forest Service uses in the National Fire Danger Rating. Colorado issues a danger rating for 3 elevation bands, above tree line, near tree line, and below tree line.

$$
\hat{A}_{t}=F\left(\hat{A}_{t-1}, E\left(W_{t}\right), Q_{F_{t-1}}, Q_{P_{t-1}}\right)
$$

I model the advisory bulletin production function as Equation 2.1. The daily advisory bulletin, $\hat{A}_{t}$, is a function the previous bulletin which is augmented and updated by the experience and knowledge of the forecaster using current information. This current information is a set of inputs including the expectation of the day weather, $E\left(W_{t}\right)$, and the recent field observations gathered by the forecasters, $Q_{F}$, and submitted by the public, $Q_{P}$. I assume that forecasters objective function is to minimize

the difference between their published advisory bulletin, $\hat{A}$, and the true underlying riskiness of the snowpack, $A$, which is unobserved.

The functional form of equation 2.1 is an opaque human decision. Extensive developments in statistically driven snow assessment have occurred since the introduction of the SNOWPACK model system (Bartelt and Lehning, 2002). Recent developments are largely targeted at problem specific or location specific prediction and still require a final judgment call by a human avalanche forecaster to 
create a holistic forecast. For example, Bakermans and Jamieson (2009) and Bellaire et al. (2017) build models using meteorological data to provide additional information to forecasters about the little understood wet avalanche problems, but require final human interpretation in the formulation of

the advisory bulletin, $\hat{A}$. These statistical meteorological models are designed to supplement human generated information from the field, $Q$, which the forecaster traditionally observes at a very sparse rate.

$$
\begin{gathered}
Q_{F_{t}}=F_{F}\left(\hat{A}_{t}, W_{t}, Q_{F_{t-1}}, Q_{P_{t-1}}\right) \\
Q_{P_{t}}=F_{P}\left(\hat{A}_{t}, W_{t}, Q_{F_{t-1}}, Q_{P_{t-1}}, t\right)
\end{gathered}
$$

Information is supplied by the forecasters in equation 2.2 and by the private backcountry users according to equation 2.3. Both parties make travel decision based on the daily advisory, $\hat{A}_{t}$, and the weather on that day, both of which affect terrain travel decision by each party and what they can observe. Additionally, demand for current information in $t$ is a function of the quantity and type of information gathered in $t-1$ by both parties. I include $t$ in equation 2.3 because the number of backcountry travelers is greatly affected by the draw of t from the set of days in the week. There will be a lot more people in or near avalanche terrain on weekends relative to weekdays. The forecasting offices run at a relatively stable staffing level 7 days a week throughout the season so I assume the draw of $t$ does not affect equation 2.2.

\subsubsection{Backcountry Users, Private Investments in Safety, and the Avalanche Bulletin}

In the US, safety measures are often mandated for many activities both mundane and recreational. Seat belt laws reduce fatalities but do not appear to increase dangerous driving (Carpenter and Stehr, 2008; Cohen and Einav, 2003). Boaters are required to have personal flotation devices for every person on board. In addition to this policy, formal instruction may be required for some 
boat operators and both of these methods are shown to reduce accident severity (McCarthy and Talley, 2001). Bicycle helmet laws have been widely adopted in North American and evidence from Canada suggests that the laws had the intended effect of increasing bicycle helmet use (Carpenter and Warman, 2019). Recreating in avalanche terrain differs, however, because personal safety measures and training are not required or mandatory.

There is a standard set of practices that avalanche professionals recommend. This starts with extensive private investment in equipment and skills by a backcountry user before venturing into avalanche terrain. The necessary equipment for travel in avalanche terrain starts with an avalanche transceiver (beacon), shovel, and probe used to locate and extract a buried victim. These are also required items for any avalanche safety course, which is the next recommended private investment. In the US, avalanche education is conducted by the American Institute for Avalance Research and Education (AIARE). I will summarize a generalized decision sequence taught in a introductory AIARE course for backcountry users.

1. When deciding whether to head to the backcountry and in or around avalanche terrain, read the avalanche advisory for the day.

2. If a decision is made to enter avalanche terrain, consider a route that minimizes risk based on the information in the advisory.

3. Collect own supplementary information in the field.

4. Continue to adjust (or not) the route based on the information from the advisory and personal observations.

There are two important trade-offs faced by a backcountry user which make the advisory bulletin relevant. Most people do not enter avalanche terrain just for the thrill of risk exposure alone, but because ideal slope angles for skiing are also prime avalanche terrain. ${ }^{5}$ In addition to this, avalanche danger is also increasing with snow quality. For example, most skiers would prefer fresh, soft snow

\footnotetext{
${ }^{5}$ Most avalanches occur on slope angles between $30^{\circ}$ and $45^{\circ}$.
} 
from a recent storm as opposed to old, refrozen snow on which it is harder to control skis or a snowmobile. The old refrozen snow is likely to have a stronger bond to other snow layers compared to the recent storm snow which is more likely to slide, ceteris paribus. Without overgeneralizing, the more enjoyable the snow and terrain conditions are for the backcountry user, the higher the danger associated with avalanches.

These trade offs require the backcountry user to venture out on days where the danger level is raised if she is searching for better snow conditions. The avalanche advisory danger levels in figure ?? are a pretty coarse signal. Two considerable danger days may be rated as such for separate reasons and a specific location might carry a high risk one day, but be a safer alternative under separate circumstances. Additionally there is substantial variation in prescribed danger ratings between forecasters when operating on the same information sets (Lazar et al., 2016). In the spirit of mountaineering, individuals are left to take the level of risk they are willing to accept.

Stated preference research into backcountry users weighing this avalanche danger trade off that suggests individuals are less likely to enter avalanche terrain when increased avalanche danger is communicated by a forecast or other information (Furman, Shooter, and Schumann, 2010; Haegeli et al., 2010). While this is informative, the limitations of applying stated preference data to understand decisions by individuals in avalanche terrain are conspicuous. There is limited research done with revealed preferences, but there is one project currently collecting data on individual route choices (Hendrikx and Johnson, 2014). Using individual GPS files is a great descriptive improvement. However identifying causality is difficult given the inability to experiment with forecast products and selection into reporting. McCammon and Hägeli (2004) examine accident accounts to compare different decision method's ability to prevent avalanche accidents. However, most of the methods considered use the forecast as an input. This paper is the first to attempt to identify causal effects of avalanche forecasting products on the extensive margin. 


\subsubsection{Colorado Season Extension}

Avalanche centers across the US cease daily forecasting when the snowpack consolidates to spring conditions, usually around mid-April depending on the magnitude of the winter. However, many backcountry users still venture out in springtime, and snow at high elevations in the alpine is common in April and May. At the request of their government and private principals, the Colorado Avalanche Information Center (CAIC) stayed open through the end of May in 2019. The CAIC conducted daily avalanche forecasting for all 10 zones seen in Figure 2.2 through May 1st. For the remainder of May, the CAIC issued a daily forecast that covered all 10 zones, but combined them into 3 groups; Northern, Central, and Southern mountains. ${ }^{6}$ All zones were covered, but in a slightly more general forecast.

The Utah Avalanche Center (UAC) ceased daily forecasting in mid-April in 2019 as they and the CAIC did historically. These Colorado specific policy changes make for a quasi-natural experiment to examine the impact of avalanche forecasting services on incidents in the backcountry. The difference in timing can be seen in the vertical lines which represent closing dates in Figure 2.3.

\subsection{Data}

The data sample covers 1/1/14 through 2018/19 season in the forecasted zones in Colorado and Utah, shown in Figures 2.1 and 2.2 respectively. I consider a full avalanche season to run from November 1st to May 31st. Within that time frame, the avalanche centers will begin daily forecasting typically sometime mid-November to mid-April depending on the weather in that zone and year. The days before (after) daily forecasting starts (ends) are coded as no forecast. While daily forecasting may not be occurring, this does not mean the avalanche risk is zero or that backcountry users cease travel in avalanche terrain. The observation forums for each zone remain active throughout the year so people can report information and incidents out of daily forecasted dates.

\footnotetext{
${ }^{6}$ The Northern Zone consisted of the Front Range, Steamboat, and Vail zones. Aspen, Gunnison, Grand Mesa and the Sawatch zones became the Central Mountains, and Sangre De Cristo, Northern San Juans, and Southern San Juans made the Southern Mountains.
} 


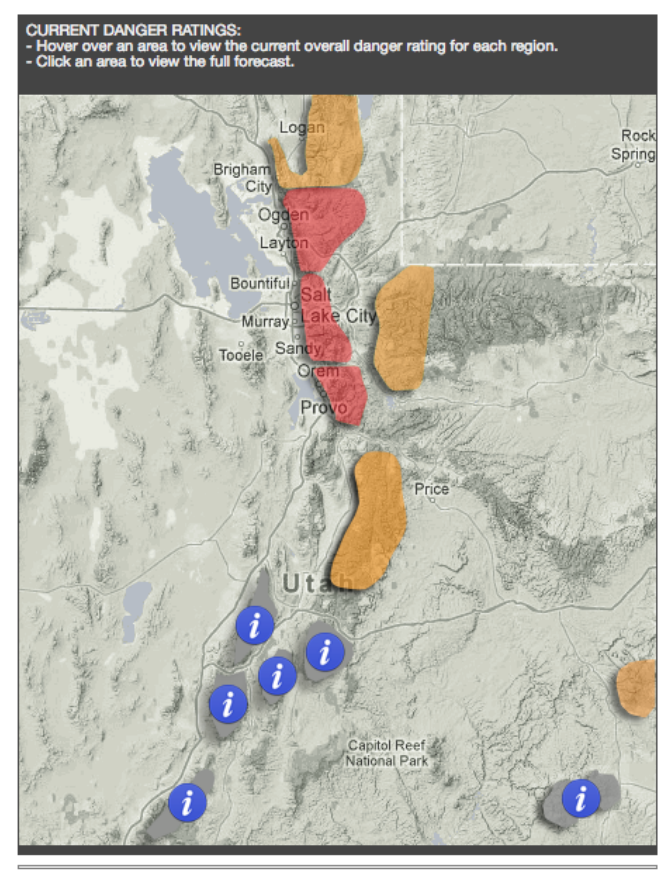

Figure 2.1: Utah Zone Danger

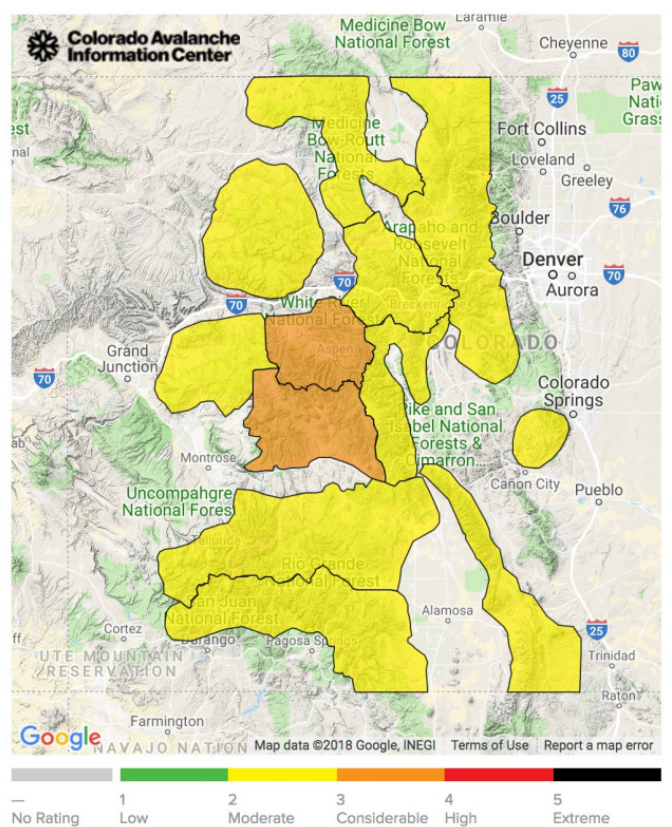

Figure 2.2: Colorado Zone Danger

I collected observation data from the forums on the CAIC and UAC websites. From the information in the observation data I separate observations by: source, forecaster and professional observer or general public; and type, accident, human triggered avalanche, natural avalanche, or general field observation. This is aggregated at the daily forecasted zone level using the 10 zones in Colorado and 8 zones in Utah. I cross validate the main dependent variables of interest, human triggered avalanches and accidents, with the CAIC and UAC avalanche databases. Forecasters record all avalanche reports they receive and code all information in a standard record format, including trigger source, avalanche type, destructive size, run length, etc. I only consider avalanche observations from the forums that I can match to an accident or an unintentionally human triggered slide in the avalanche databases. The CAIC and UAC have different standards for recording accidents, so I lump both accidents and unintentional human triggers that are not coded as accidents into my outcome of interest, incidents. ${ }^{7}$ There are 771 total incidents across the sample in Colorado and 1055 in Utah. In Figure 2.3 I present the incident totals by week for Colorado and Utah across the 2016/17 season to the 2018/19 season

\footnotetext{
${ }^{7}$ Not all human triggered avalanches should be considered incidents. Certain techniques such as a 'ski cut' can be used by backcountry users to asses stability so I remove these intentionally triggered avalanches from the outcome of interest.
} 
with the vertical lines representing the CAIC and UAC open and closing dates for the season. 
Figure 2.3: Incidents in Colorado in Utah

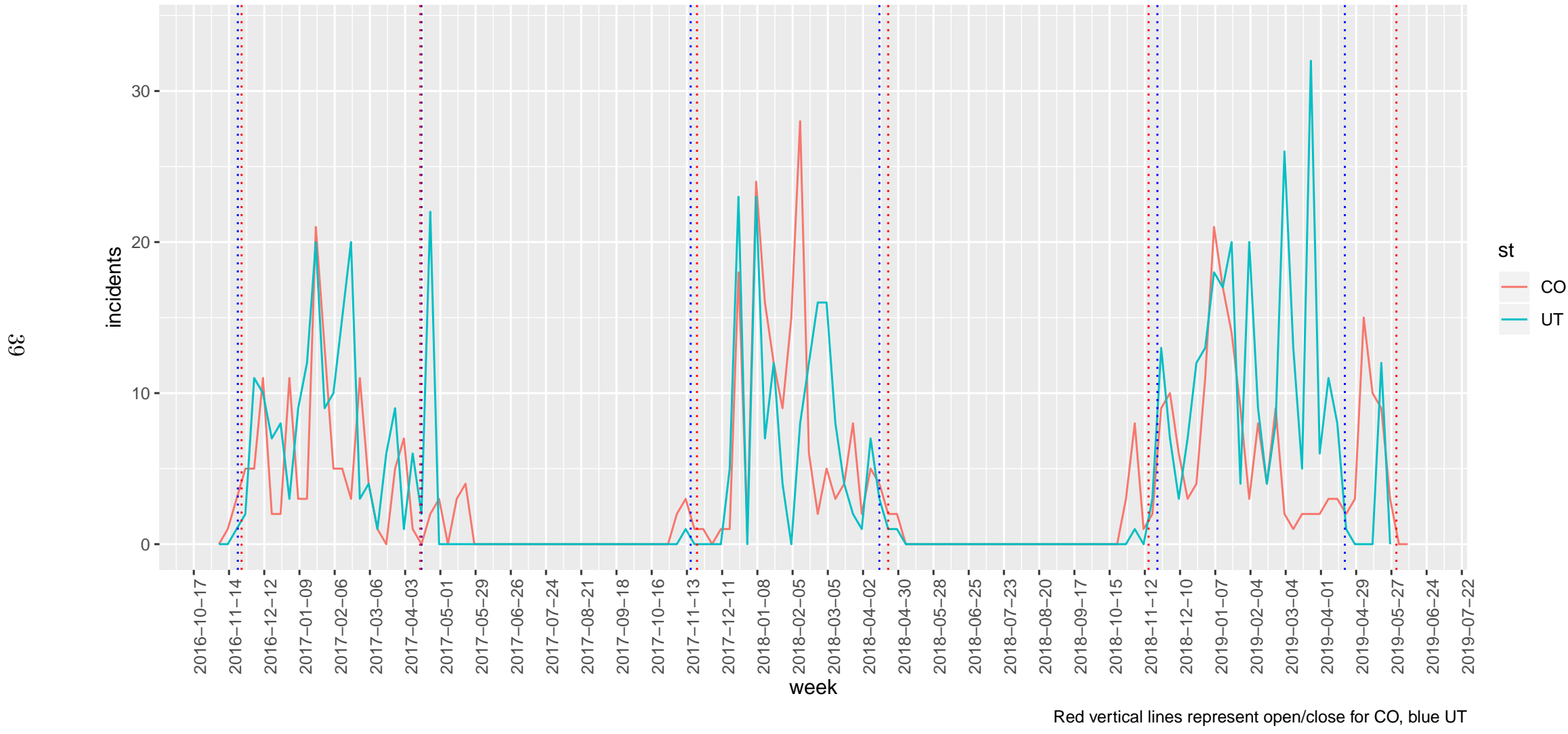


Figure 2.4: Average reported avalanches and incidents across season in Colorado

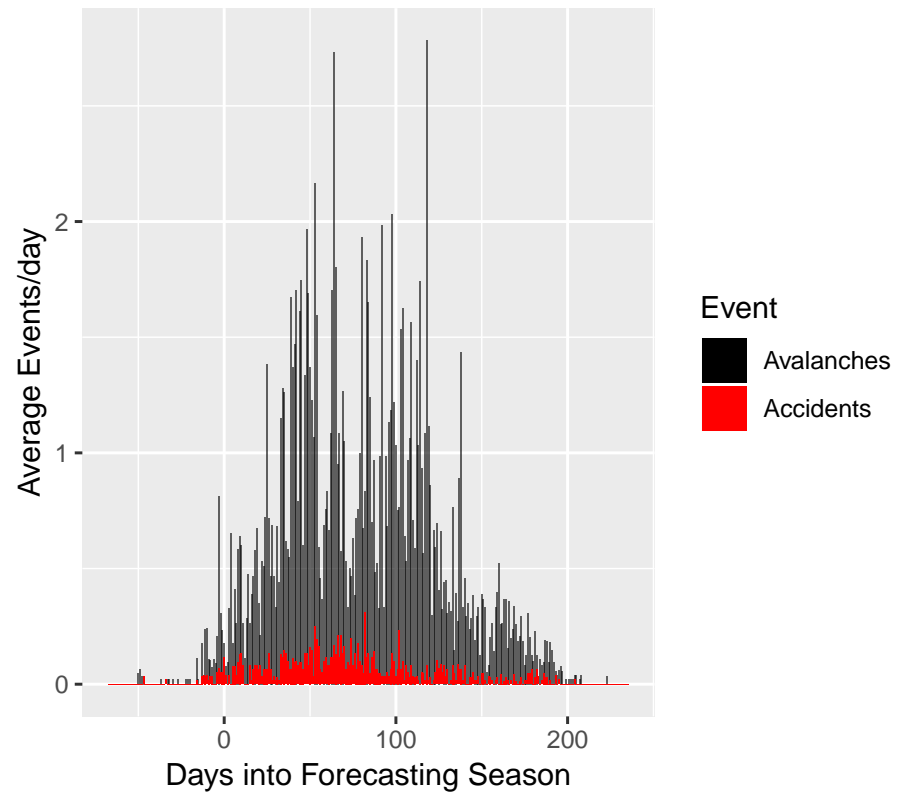

On average there is a reported incident once every 10 days in a zone and roughly 16 percent of all incidents are accidents where a person is buried or harmed. This rate is pretty variable across the season from a visual inspection of Figure 2.3. This variation across the season is largely due to weather patterns. Figures 2.5 and 2.6 show the incident and accident rate by danger rating. The incident and accident conditional means both increase with danger ratings. This is suggestive that there is not a dominant displacement effect of human involved avalanche incidents from high danger days to lower danger days caused by increased travel on relatively lower danger days. Other avalanches include all other reported avalanches that are not coded as incidents. These could be reported natural avalanches or could result from human intent such as control work above highways. The average other avalanche reporting rate across the season is shown in Figure 2.4. The average daily accident rate throughout the season is also shown. Forecaster and public observations are the other field reports in the observation forums that are not avalanches such as snow profiles and weather information.

I obtain weather data from the US Department of Agriculture Snow Telemetry (SNOTEL) snow monitoring stations. These are weather stations placed in mountain ranges to monitor snowfall and 


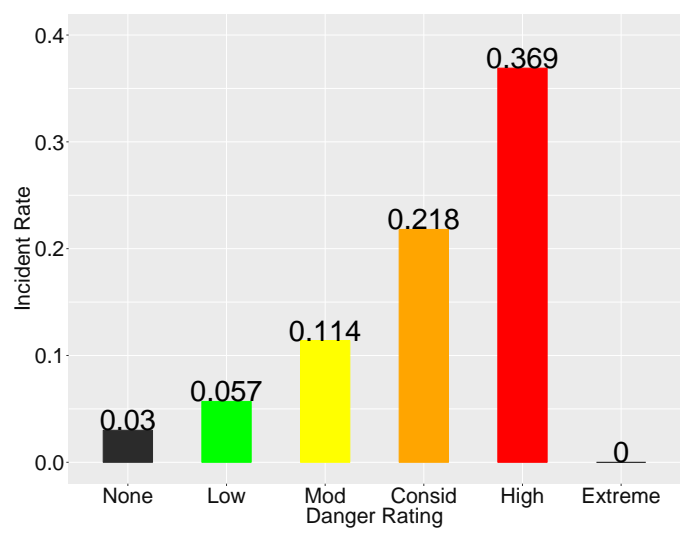

Figure 2.5: Incidents per danger rating

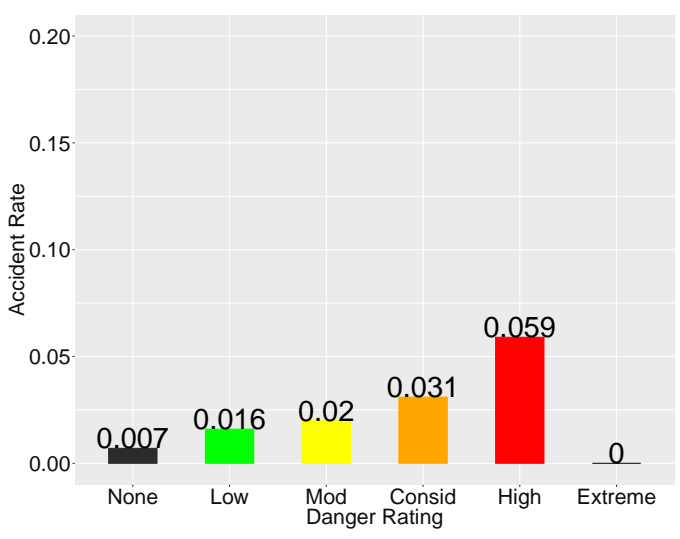

Figure 2.6: Accidents per danger rating

snowpack levels. ${ }^{8}$ Because the SNOTEL network's primary function is not avalanche forecasting data, there is not a representative set of stations in each zone across different elevations. I select the SNOTEL site in a zone that collects both snow and temperature data and is closest to a consistent elevation in each state. ${ }^{9}$

The weather variables include the minimum, average, and high temperature for the day at the SNOTEL site. The data on snowfall includes the amount of new precipitation in snowfall and adjusted to rain with snow water equivalent, the depth of the snowpack at the SNOTEL site and the snowpack's average density.

The CAIC and UAC publish their daily avalanche forecasts in slightly different formats. CAIC publishes a danger rating from Figure ?? for 3 elevation levels: below treeline, near treeline, and above treeline and then provides supplemental information by compass aspect, while the UAC forecast separates the forecast danger level by elevation and compass aspect. To create a comparable forecast variable, I use the highest danger level published in the forecast at any aspect or elevation for the day. ${ }^{10}$ This abandons much of the other pieces of information included in the forecast for a specific zone day, such as the avalanche problem types. The manner I have chosen to consolidate the forecast information into a variable is consistent with the graphical presentation that the CAIC and UAC use

\footnotetext{
${ }^{8}$ These stations are primarily used to record data to predict snow melt and run off amounts as the snow melts in the spring, however they also serve as a primary data source for avalanche forecasters.

${ }^{9} 9000 \mathrm{ft}$ in Utah, $10500 \mathrm{ft}$ in Colorado.

${ }^{10}$ This is consistent with other presentation of the forecast. The verbal summary of the forecast typically begins with the highest level published. For example, if the forecast is moderate everywhere except north facing high elevations which are considerable, the summary would say "The forecasted danger today is CONSIDERABLE...".
} 
Table 2.1: Zone Summary Statistics

\begin{tabular}{lccccccc}
\hline \hline Statistic & $\mathrm{N}$ & Mean & St. Dev. & Min & Pctl(25) & Pctl(75) & Max \\
\hline Accident & 17,767 & 0.02 & 0.15 & 0 & 0 & 0 & 4 \\
Incident & 17,767 & 0.10 & 0.48 & 0 & 0 & 0 & 14 \\
Other Avy & 17,767 & 0.50 & 1.98 & 0 & 0 & 0 & 65 \\
Forecaster Obs & 17,767 & 0.40 & 0.84 & 0 & 0 & 1 & 10 \\
Public Obs & 17,767 & 0.21 & 0.56 & 0 & 0 & 0 & 9 \\
Temp Av & 17,767 & 28.87 & 10.63 & -13 & 22 & 36 & 64 \\
Temp High & 17,767 & 39.24 & 11.32 & -4 & 31 & 47 & 87 \\
Temp Min & 17,767 & 19.71 & 11.79 & -31 & 12 & 28 & 55 \\
Snowfall & 17,767 & 1.53 & 4.47 & 0 & 0 & 1 & 289 \\
Precip Increment & 17,764 & 0.15 & 0.29 & 0.00 & 0.00 & 0.20 & 3.90 \\
Precip Accum & 17,765 & 16.58 & 11.34 & 0.20 & 8.30 & 21.90 & 76.70 \\
Snowdepth & 17,767 & 38.17 & 27.07 & 0 & 19 & 52 & 155 \\
Snow Water Eqv. & 17,767 & 12.18 & 10.43 & 0.00 & 4.60 & 16.70 & 58.00 \\
Snow Density & 17,767 & 27.63 & 12.59 & 0.00 & 22.00 & 35.40 & 90.00 \\
Snow Rain Ratio & 7,313 & 83.84 & 71.97 & 0.00 & 0.00 & 100.00 & $1,000.00$ \\
\hline
\end{tabular}

on their web homepages. For example, Figure 2.2 shows the maximum danger in 8 zones as moderate (yellow), and 2 zones as considerable (orange), on a forecasted day. For the treatment period in Colorado that uses the 3 zone format, I use the same method, just applying the aggregated forecast to each covered zone.

In Figure 2.7 I present the forecast distribution by state in the sample. ${ }^{11}$ Moderate danger ratings are a clear mode for CAIC forecasters, while the max danger ratings produced by the UAC are more evenly distributed. Overall, 14 percent of days were rated low, 34 percent moderate, 15 percent considerable, and 3 percent high. Extreme danger ratings are seldom used by both centers, only 5 times across the sample in Colorado and 4 in Utah.

\subsection{Methods and Empirical Results}

To better isolate the impact of avalanche forecasting services on outcomes I exploit the forecasting season extension in Colorado for 2019 and use Utah as a control. As discussed earlier, CAIC's contract with the State required them to continue forecasting each zone until the end April and then

\footnotetext{
${ }^{11}$ This graph shows the distribution in the sample. It is not adjusted to account for the different number of zones between Colorado and Utah.
} 
Figure 2.7: Total danger forecasted days distribution by state.

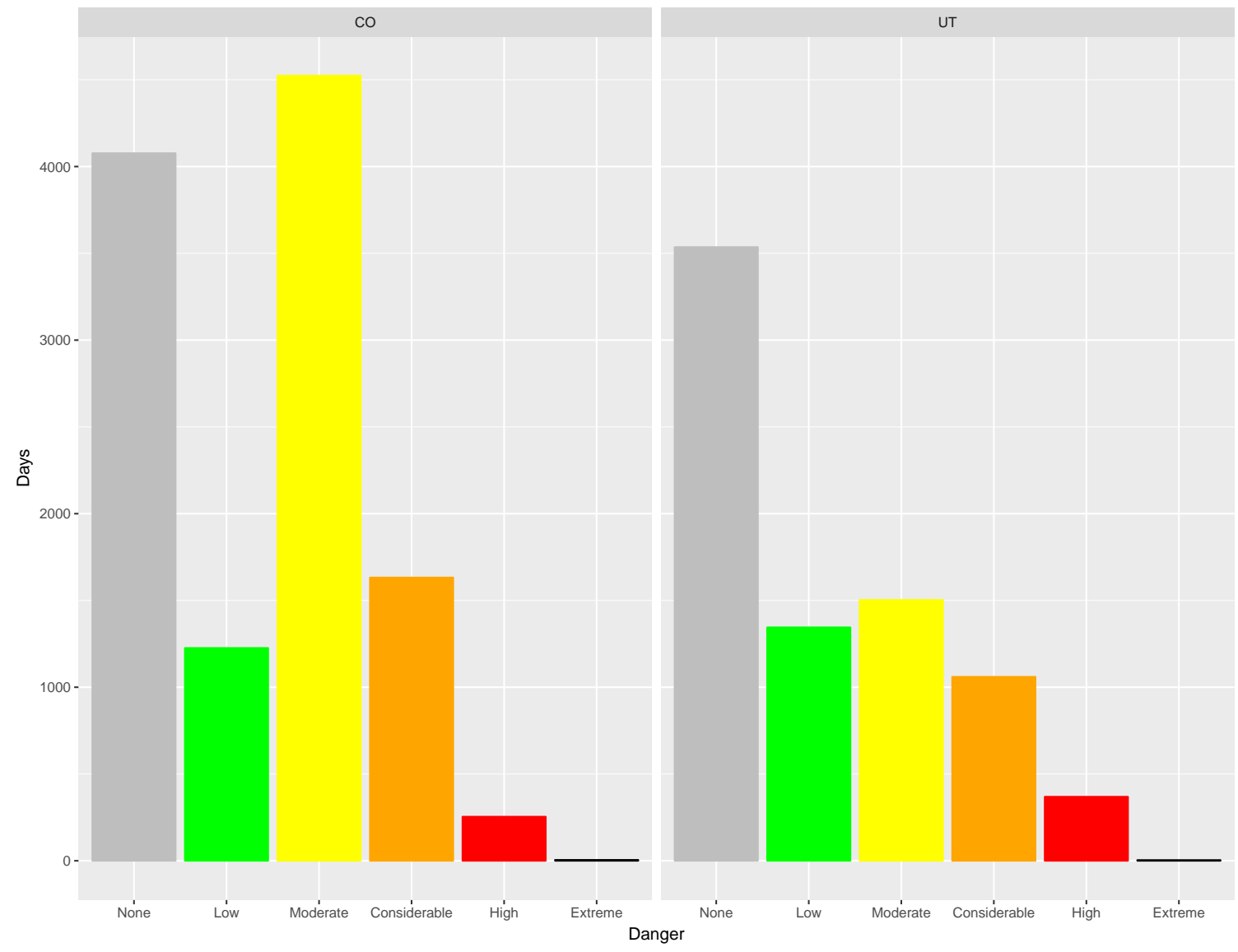


continue on a reduced format through May. Utah ceased daily forecasting activities on April, 20th, 2019 per their usual method of operations.

\subsubsection{Control Variable Selection}

Colorado and Utah both experienced above average snowfall in the winter of 2018-19. However, the extremely stochastic nature of mountain weather across space can create omitted variable bias between zones and cannot be removed with fixed effects. I need a robust set of weather variables that would remove different avalanche risks affecting outcomes in Colorado and Utah that are due to separate weather patterns across zones. Intraday spatial heterogeneity must be accounted for, else further experimental design assumptions are suspect at best.

The underlying avalanche danger is likely a complex set of weather variables and interactions. To select the ideal set of weather controls, I use a penalized regression procedure with all reported avalanche activity as the outcome and consider the 10 weather variables, their squared terms, and all possible pairwise interactions as explanatory variables. I select an elastic net over other methods because of the grouping effect (Zou and Hastie, 2005). The weather control variables are highly correlated within groups of temperature, precipitation, and snowpack, making elastic net preferable over LASSO. I also consider a LASSO method for robustness. The weather control variables selected by these models are shown in Tables 2.5 and 2.6 .

Table 2.2 presents a basic panel model with the forecast and observation variables and differing weather controls regressed on the main outcome of interest, human involved avalanche incidents. Including the full set of weather control variables generated by elastic net and LASSO slightly mutes the magnitude of the forecast danger level on incidents in model 4 and 6 , but positive coefficients and an increasing gradient across danger ratings remains. 
Table 2.2: Panel models with weather controls

\begin{tabular}{|c|c|c|c|c|c|c|}
\hline & \multicolumn{6}{|c|}{ Dependent variable: } \\
\hline & \multicolumn{6}{|c|}{ Incidents } \\
\hline & $(1)$ & $(2)$ & $(3)$ & $(4)$ & $(5)$ & $(6)$ \\
\hline No Forecast & $\begin{array}{c}0.013 \\
(0.019)\end{array}$ & & & $\begin{array}{l}0.042^{*} \\
(0.022)\end{array}$ & & $\begin{array}{l}0.039^{*} \\
(0.023)\end{array}$ \\
\hline Moderate & $\begin{array}{c}0.065^{* * *} \\
(0.024)\end{array}$ & & & $\begin{array}{c}0.059^{* *} \\
(0.028)\end{array}$ & & $\begin{array}{c}0.058^{* *} \\
(0.028)\end{array}$ \\
\hline Considerable & $\begin{array}{c}0.119^{* * *} \\
(0.033)\end{array}$ & & & $\begin{array}{c}0.105^{* * *} \\
(0.030)\end{array}$ & & $\begin{array}{c}0.102^{* * *} \\
(0.029)\end{array}$ \\
\hline High & $\begin{array}{c}0.222^{* * *} \\
(0.084)\end{array}$ & & & $\begin{array}{c}0.211^{* * *} \\
(0.073)\end{array}$ & & $\begin{array}{c}0.207^{* * *} \\
(0.075)\end{array}$ \\
\hline Extreme & $\begin{array}{c}-0.160^{* *} \\
(0.078)\end{array}$ & & & $\begin{array}{l}-0.137 \\
(0.086)\end{array}$ & & $\begin{array}{l}-0.142 \\
(0.087)\end{array}$ \\
\hline Other Avy & $\begin{array}{c}0.016 \\
(0.013)\end{array}$ & & & $\begin{array}{c}0.016 \\
(0.013)\end{array}$ & & $\begin{array}{c}0.016 \\
(0.013)\end{array}$ \\
\hline Public Obs & $\begin{array}{c}0.067^{* *} \\
(0.030)\end{array}$ & & & $\begin{array}{c}0.064^{* *} \\
(0.030)\end{array}$ & & $\begin{array}{c}0.064^{* *} \\
(0.030)\end{array}$ \\
\hline Forecaster Obs & $\begin{array}{c}0.069 \\
(0.045)\end{array}$ & & & $\begin{array}{c}0.065 \\
(0.042)\end{array}$ & & $\begin{array}{c}0.065 \\
(0.042)\end{array}$ \\
\hline Av. Temperature & & $\begin{array}{c}-0.007^{* *} \\
(0.003)\end{array}$ & $\begin{array}{c}-0.0003 \\
(0.002)\end{array}$ & $\begin{array}{c}0.001 \\
(0.002)\end{array}$ & $\begin{array}{c}0.0002 \\
(0.002)\end{array}$ & $\begin{array}{c}0.001 \\
(0.002)\end{array}$ \\
\hline Low Temperature & & $\begin{array}{c}0.002 \\
(0.001)\end{array}$ & & & & \\
\hline High Temperature & & $\begin{array}{c}0.002^{* *} \\
(0.001)\end{array}$ & & & & \\
\hline Snowfall & & $\begin{array}{l}0.0003 \\
(0.002)\end{array}$ & & & & \\
\hline Precip Inc & & $\begin{array}{c}0.076 \\
(0.061)\end{array}$ & $\begin{array}{c}0.104 \\
(0.090)\end{array}$ & $\begin{array}{c}0.012 \\
(0.060)\end{array}$ & $\begin{array}{c}0.108 \\
(0.089)\end{array}$ & $\begin{array}{c}0.015 \\
(0.061)\end{array}$ \\
\hline Precip Accum. & & $\begin{array}{c}-0.0001 \\
(0.001)\end{array}$ & & & & \\
\hline Snow Depth & & $\begin{array}{c}0.004^{* * *} \\
(0.001)\end{array}$ & $\begin{array}{c}0.005^{* * *} \\
(0.001)\end{array}$ & $\begin{array}{c}0.001 \\
(0.002)\end{array}$ & $\begin{array}{c}0.006^{* * *} \\
(0.001)\end{array}$ & $\begin{array}{c}0.001 \\
(0.002)\end{array}$ \\
\hline Snow Water Eqv. & & $\begin{array}{c}-0.006^{* *} \\
(0.003)\end{array}$ & & & & \\
\hline Snow Density & & $\begin{array}{c}0.0001 \\
(0.0004) \\
\end{array}$ & $\begin{array}{c}-0.002^{*} \\
(0.001) \\
\end{array}$ & $\begin{array}{l}-0.001 \\
(0.001)\end{array}$ & $\begin{array}{l}-0.002 \\
(0.001)\end{array}$ & $\begin{array}{l}-0.001 \\
(0.001)\end{array}$ \\
\hline Weather Controls & - & Level & Elastic Net & Elastic Net & Lasso & Lasso \\
\hline Zone x Season FEs & $\mathrm{Y}$ & $\mathrm{Y}$ & $\mathrm{Y}$ & $\mathrm{Y}$ & $\mathrm{Y}$ & $\mathrm{Y}$ \\
\hline Observations & 17,817 & 17,814 & 17,814 & 17,814 & 17,814 & 17,814 \\
\hline $\mathrm{R}^{2}$ & 0.131 & 0.107 & 0.114 & 0.141 & 0.115 & 0.141 \\
\hline Adjusted $\mathrm{R}^{2}$ & 0.127 & 0.102 & 0.108 & 0.134 & 0.109 & 0.135 \\
\hline Residual Std. Error & 0.454 & 0.461 & 0.459 & 0.452 & 0.459 & 0.452 \\
\hline
\end{tabular}

\subsubsection{Colorado Season Extension Difference in Differences}

Figure 2.8 shows the average daily incident rate binned by weeks up to close in the seasons prior to the Colorado policy change. There will always be variance due to the stochastic nature of avalanche incidents, but Colorado and Utah follow similar paths across the course of the season. The average incident rate is trending down in both states each week further into spring. The pattern is very similar around the chosen closing date in both states, which is important for identification. While there is more variance from week to week in Utah after close relative to Colorado, the average 
Figure 2.8: Average daily accident rate around closing date.

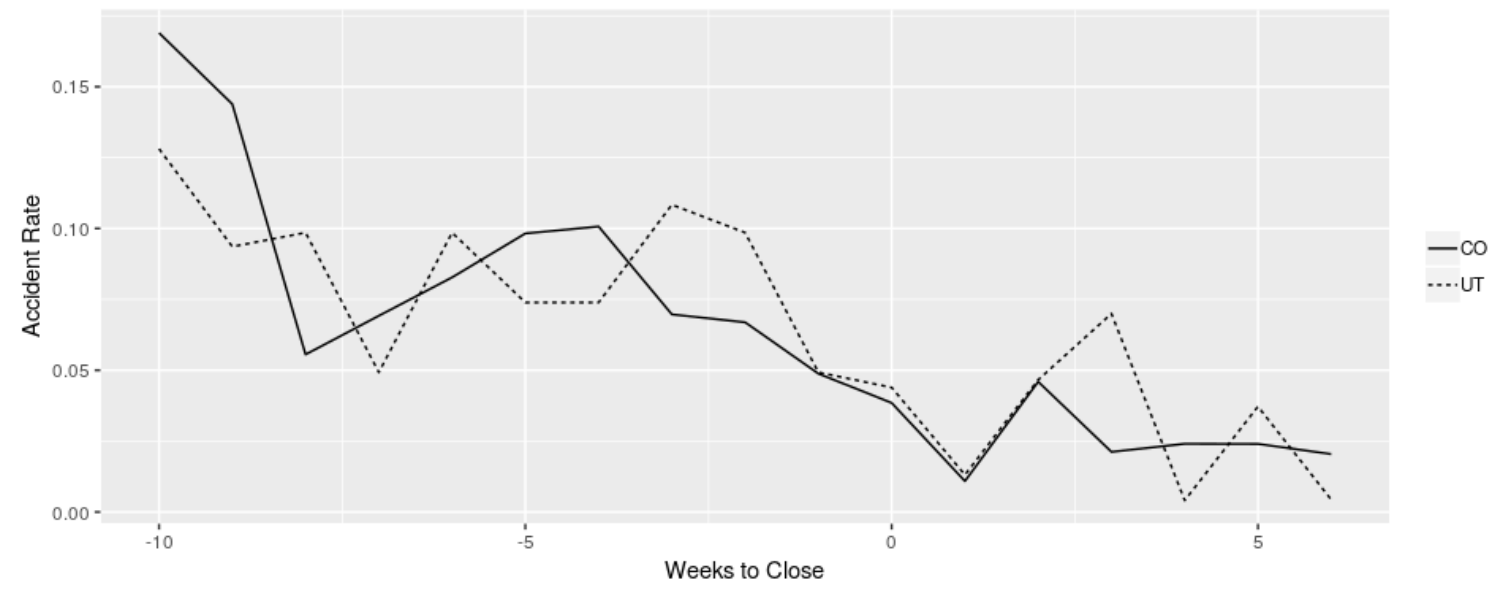

incidents across this time are similar.

I estimate a difference in difference model shown in equation 2.4 using the Utah zones as controls when Colorado extends forecasting in 2019. I use the highest forecasted danger level at any elevation or aspect for the days forecast, because Utah and Colorado report daily avalanche forecasts in slightly different formats. A zone day receives a published advisory bulletin, $A_{z t}$, or the forecast center is closed, Postseason $z$. I want to estimate what happens to incidents when Colorado stays open longer in 2019. The coeffecient of interest becomes $B_{5}$, interaction of the postseason (based on the last forecast in Utah), with forecasting in Colorado. Models include weather controls at the zone day, $X_{z t}$, and various fixed effects $\gamma_{z t}$. Standard errors are clustered on zone and season. These results are shown in Table 2.3.

$$
\begin{aligned}
\text { Inc }_{z t}= & B_{1} A_{z t}+B_{2} \text { Postseason }_{z} t+B_{3}\left(\text { Postseason }_{z} t * C O_{z}\right)+B_{4}\left(C O_{z} * A_{z t}\right)+ \\
& B_{5}\left(\text { Postseason }_{t} * A_{z t} * C O_{z}\right)+X_{z t}+\gamma_{z t}+\epsilon_{z t}
\end{aligned}
$$

Models 2 and 3 add in zone by season fixed effects and month and day of week fixed effects, respectively. Models 4-6 replicate 1-3 with the inclusion of the set of weather controls selected in Table 2.5. The results from the differences models suggest, conservatively, a .11 reduction in incidents on considerable rated days when the CAIC continued its forecasting efforts through May. There is 
a slight increase in incidents occurring on days rated low. These results are duplicated with level weather variables and the LASSO selected weather controls in Table 2.7. I only consider incidents as an outcome variable with this design because severe avalanche accidents are extremely rare during the time of year that becomes treated. There are only 8 accidents during the postseason in Colorado in the entire sample.

Table 2.3: Difference in Differences Models

\begin{tabular}{|c|c|c|c|c|c|c|}
\hline & \multicolumn{6}{|c|}{ Dependent variable: } \\
\hline & \multicolumn{6}{|c|}{ Incidents } \\
\hline & $(1)$ & $(2)$ & $(3)$ & $(4)$ & $(5)$ & $(6)$ \\
\hline Low CO Extension & $\begin{array}{c}0.046^{* * *} \\
(0.009)\end{array}$ & $\begin{array}{c}0.024 \\
(0.023)\end{array}$ & $\begin{array}{l}0.048^{*} \\
(0.026)\end{array}$ & $\begin{array}{c}0.051^{* * *} \\
(0.017)\end{array}$ & $\begin{array}{c}0.038^{* *} \\
(0.017)\end{array}$ & $\begin{array}{l}0.032^{*} \\
(0.018)\end{array}$ \\
\hline Moderate CO Extension & $\begin{array}{l}-0.026 \\
(0.021)\end{array}$ & $\begin{array}{c}-0.034^{* *} \\
(0.019)\end{array}$ & $\begin{array}{c}0.007 \\
(0.022)\end{array}$ & $\begin{array}{l}-0.011 \\
(0.015)\end{array}$ & $\begin{array}{c}0.002 \\
(0.015)\end{array}$ & $\begin{array}{c}0.006 \\
(0.016)\end{array}$ \\
\hline Considerable CO Extension & $\begin{array}{c}-0.104^{*} \\
(0.056)\end{array}$ & $\begin{array}{c}-0.112^{* * *} \\
(0.041)\end{array}$ & $\begin{array}{l}-0.059 \\
(0.042)\end{array}$ & $\begin{array}{c}-0.158^{* *} \\
(0.076)\end{array}$ & $\begin{array}{c}-0.121^{* *} \\
(0.053)\end{array}$ & $\begin{array}{c}-0.113^{* *} \\
(0.052)\end{array}$ \\
\hline Zone $\mathrm{x}$ Season FEs & - & $\mathrm{Y}$ & $\mathrm{Y}$ & - & $\mathrm{Y}$ & $\mathrm{Y}$ \\
\hline Day of Week and Month FEs & - & - & $\mathrm{Y}$ & - & - & $\mathrm{Y}$ \\
\hline Weather Controls & - & - & - & $\mathrm{Y}$ & $\mathrm{Y}$ & $\mathrm{Y}$ \\
\hline Observations & 17,638 & 17,638 & 17,638 & 17,635 & 17,635 & 17,635 \\
\hline $\mathrm{R}^{2}$ & 0.041 & 0.116 & 0.121 & 0.052 & 0.127 & 0.130 \\
\hline Adjusted $\mathrm{R}^{2}$ & 0.041 & 0.111 & 0.115 & 0.049 & 0.120 & 0.122 \\
\hline
\end{tabular}

\subsubsection{Robustness}

One threat to identification in this setting is the self-reported nature of incidents. The majority of human involved avalanche incidents in my sample are reported by the party that was caught in the event. This presents a few potential problems for required assumptions for difference in difference methods. Particularly, if the probability that a party involved in an avalanche incident chooses to report the incident changes when an avalanche forecasting center opens or closes, then the estimates in Table 2.3 would be biased. This could work in two ways. If the probability that an involved party reports an incident increases after a center closes, then it would positively bias my results. The 
probability a group reports an incident may decrease after an avalanche center closes since it is not being used in the forecast.

Information about avalanche conditions can be considered a local public good. Returning to the model in equations 2.1 and 2.3, if private backcountry users receive direct utility from from reporting information and incidents, closure may increase $Q_{P}$ through two channels. First, if $Q_{F}$ and $Q_{P}$ are substitutes then public information provision crowds out private information provision, meaning $\frac{\partial Q_{P_{t}}}{\partial Q_{F_{t}}}<0$. This would support standard free riding behavior during the season. However, when the avalanche center ceases daily forecasting and $Q_{F}$ decreases, then private backcountry users may increase reporting bearing more of the burden of providing the public good. Second, since forecasters are not producing a daily forecast, the marginal benefit of reporting directly to peers might increase for private backcountry users. The direct utility of $Q_{P}$ as a resource to others would increase in absence of $\hat{A}_{t}$ and outweigh the utility gained from $Q_{P}$ as an input to $\hat{A}_{t}$. For example, if a party experiences an avalanche incident when daily forecasts are not being published, then the party might find it more pertinent to inform other backcountry users about conditions because their report is the only possible source of that information.

The converse is more concerning to identification in this setting. If the utility backcountry users gain from report information as an input into the daily forecast outweighs the utility from providing information directly to peers, then reported observations from backcountry users would decrease when the forecasting center closes. This would negatively bias the effect of daily forecasting on incidents in Table 2.3. This bias would make it appear that forecasting decreases incidents because fewer incidents are reported, when the true effect of forecasting on incidents would be null.

To test these possible channels that forecasting services would have on reporting rates from private backcountry users, I replicate model estimated in equation 2.4 but replace the outcome, incidents, with all other private reports. These include reported naturally triggered avalanches and general field observations about weather and snow conditions. These results are presented in Table 2.4. There does not appear to be any statistically significant change in reporting. 
Table 2.4: Observation Reporting Rate Model

\begin{tabular}{|c|c|c|c|c|c|c|}
\hline & \multicolumn{6}{|c|}{ Dependent variable: } \\
\hline & \multicolumn{6}{|c|}{ Public Observations } \\
\hline & (1) & $(2)$ & $(3)$ & $(4)$ & $(5)$ & $(6)$ \\
\hline Low CO Extension & $\begin{array}{c}0.089 \\
(0.125)\end{array}$ & $\begin{array}{l}-0.015 \\
(0.121)\end{array}$ & $\begin{array}{l}-0.042 \\
(0.120)\end{array}$ & $\begin{array}{c}0.096 \\
(0.126)\end{array}$ & $\begin{array}{l}-0.028 \\
(0.121)\end{array}$ & $\begin{array}{c}-0.0002 \\
(0.121)\end{array}$ \\
\hline Moderate CO Extension & $\begin{array}{l}-0.089 \\
(0.067)\end{array}$ & $\begin{array}{l}-0.055 \\
(0.066)\end{array}$ & $\begin{array}{l}-0.046 \\
(0.067)\end{array}$ & $\begin{array}{l}-0.075 \\
(0.068)\end{array}$ & $\begin{array}{l}-0.041 \\
(0.067)\end{array}$ & $\begin{array}{l}-0.012 \\
(0.068)\end{array}$ \\
\hline Considerable CO Extension & $\begin{array}{c}-0.316 \\
(0.204)\end{array}$ & $\begin{array}{c}-0.289 \\
(0.195)\end{array}$ & $\begin{array}{c}-0.238 \\
(0.193)\end{array}$ & $\begin{array}{c}-0.307 \\
(0.204)\end{array}$ & $\begin{array}{l}-0.287 \\
(0.195)\end{array}$ & $\begin{array}{c}-0.224 \\
(0.194)\end{array}$ \\
\hline Zone x Season FEs & - & $\mathrm{Y}$ & $\mathrm{Y}$ & - & $\mathrm{Y}$ & $\mathrm{Y}$ \\
\hline Day of Week and Month FEs & - & - & $\mathrm{Y}$ & - & - & $\mathrm{Y}$ \\
\hline Weather Controls & - & - & - & $\mathrm{Y}$ & $\mathrm{Y}$ & $\mathrm{Y}$ \\
\hline Observations & 17,666 & 17,666 & 17,666 & 17,663 & 17,663 & 17,663 \\
\hline $\mathrm{R}^{2}$ & 0.102 & 0.192 & 0.212 & 0.113 & 0.205 & 0.217 \\
\hline Adjusted $\mathrm{R}^{2}$ & 0.102 & 0.187 & 0.207 & 0.111 & 0.198 & 0.210 \\
\hline
\end{tabular}

\subsection{Discussion}

The results from this policy experiment show consistent and robust reductions in avalanche incidents on considerable rated days. This is consistent with intuition. Relative to no avalanche forecasting, the introduction of forecast information should have the largest impacts on the most dangerous days. Perhaps the most intriguing result is the increase in incidents on low danger days during this policy experiment. The largest limitation of this paper is that detailed data on backcountry usage is nonexistent. Without that, it is unclear if this increase results from backcountry users substituting to lower danger days, from changes in terrain preferences, or from a combination of the two. Hopefully, current data collection on individual route choices will be able parse these mechanisms.

I argue that the decreased incidents on considerable days are a lower bound estimate for avalanche forecasting centers efficacy in reducing avalanche accidents and fatalities in the backcountry for a number of reasons. For starters, the time period used for identification is during decreasing backcountry usage. There are far more people considering travel in avalanche terrain in peak winter 
months of January to March than in late April and May. If forecasts were halted during this time, I would expect to see much larger increases in accidents than the reductions shown empirically here.

The majority of avalanche incidents occur from January to March because of increased danger and harder to assess avalanche problems in addition to the increased usage. The distribution of avalanches and incidents across the season can be seen in Figure 2.4. Forecasters present avalanche problems in 9 types, but most human involved incidents come from problem types that can be grouped into 'dry' or 'wet' problems. Higher amounts of snowfall occur during peak winter, and colder temperatures create buried weak layers that can linger and lead to dry avalanche problems. These are much more difficult for a novice to assess, and create larger, more consequential avalanches. Typically, the main avalanche problems later in the season are wet problem types, which can be generated by temperature and solar radiation melting snow or rain on the snowpack. There are many more warning signs apparent on the surface of the snowpack of increasing wet avalanche danger than dry. Much of the late season avalanche danger can be minimized by traveling early in the morning before temperatures increase and begin to melt the snow. It does not take years of experience for a backcountry user to know if their footsteps are sinking a concerning depth into melting snow. I expect forecasting services to have a greater effect of reducing accidents when problem types are harder to recognize during peak season. Because of this, and the decrease in backcountry travel later in the season, the estimates from this policy experiment generate a lower bound of the extensive effect of the the forecast.

Forecasters generally focus on encouraging backcountry users to travel early and remind them of the visual signs of rising danger in their messaging later in the season opposed to synthesizing weather and field information about more complex problems. ${ }^{12}$ When viewed in this context, it may be more appropriate to consider the effect of avalanche forecasting on incidents coming from a behavioral nudge as opposed to reduced uncertainty about an underlying risk. Separating these similar stories is not possible with the data I have used thus far. However, if more is known about

\footnotetext{
${ }^{12}$ An example of this summary messaging from the northern mountains forecast on 5/12/19 in Colorado. "...If you are traveling in steep terrain, even a small wet avalanche can knock you off your feet and send you for a dangerous ride. You will know when the chance of triggering one of these avalanches is increasing when the surface snow gets wet and gloppy. Other indicators are rollerballs and small point releases running from steep terrain. Start early and get off of slopes before these conditions take effect. If you find yourself falling into wet unconsolidated snow, it is time to move to low angle or shady slopes." Emphasis mine.
} 
Figure 2.9: Persons caught in avalanches in Colorado and fatality rate

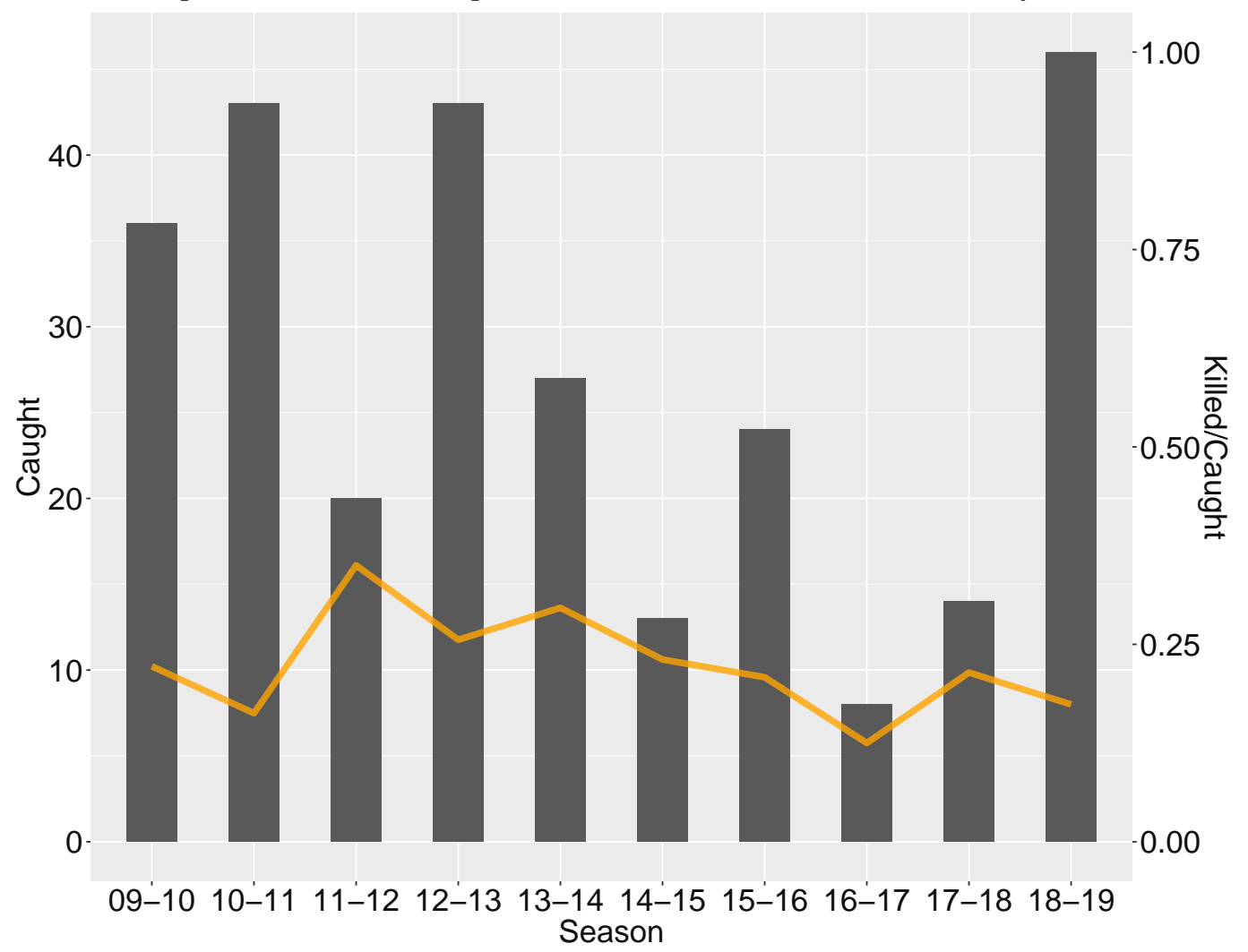

the experience level of individuals involved in avalanche incidents then it may be separable.

Additionally, the impact of forecasting on incidents likely suffers from attenuation bias. Incidents are probably under reported because people do not want to admit mistakes. Particularly among low consequence incidents where there is not a full burial, severe injury, or death, those involved may not want to add to the public record an account possibly caused by poor decision making, inexperience, or hubris. There issues with this policy evaluation all point to lower bound estimates.

While I am unable to identify an exact mechanism, it does appear that avalanche forecasting services have played a role in stunting the growth in avalanche fatalities discussed earlier. Improvements in technology and increased private investments in safety measures likely have a role, many of these would manifest in the accident survival rate. Looking specifically at Colorado, Figure 2.9 shows the total number of persons caught in avalanches over the last 10 seasons and the portion of those accidents that were fatal on the right axis. While the fatality rate may be trending downward, there is not an overwhelmingly strong pattern in the past decade. These are not mutually exclusive 
and likely private investments in safety and skills have worked along with avalanche forecasting to keep avalanche fatalities down.

So far in this paper, I have focused on the the effect avalanche forecasting services have on reported incidents of people that venture into avalanche terrain. This setting has several unique features for future work. Much of the raw information that is used to construct the forecast is available to the backcountry users in the forecaster and public observations. The efficacy of the disaggreagated peer supplied observations in altering behavior separate from the consolidated forecast perhaps can be explored with more detailed data. This becomes particularly interesting when considering avalanche forecasting services a public good which is jointly provisioned by public and private efforts.

An interesting feature of avalanche forecasting centers in the US is their accountability to multiple principals. While each avalanche center falls under the purview of the US Forest Service, the centers all have an attached non-profit which contributes to the function and funding of the center. Their annual operating budget is partially supplied by government funds and by private donations through the attached 501(c). The degree of this relationship varies by center. At one extreme, the UAC received $48 \%$ of its annual operating budget from contributions and fundraising in 2018/19, while $18 \%$ was contributed from the USFS and $11 \%$ from the State of Utah. ${ }^{13}$ In addition to these sources the UAC sells merchandise and lift tickets, which are donated by ski resorts, as well as contributions from local government organizations like fire and rescue services and earns revenue from grants.

The CAIC differs to a great degree from the institutional arrangement the UAC operates because the State of Colorado is a much larger stakeholder, partly for historical reasons. In fact, it was at the request of these principals that the CAIC extended their forecasting efforts into May in 2019 which I exploited for identification here. Accountability to multiple principals can weaken incentives for public organizations (Dixit, 1997). Further work can be done in this realm exploring the efficacy of avalanche centers when the backcountry users are larger stakeholders in supporting the center. Additionally, these avalanche centers are given large amounts of leeway in how they publish their forecasts and how they disseminate information, and this effect can be explored em-

\footnotetext{
${ }^{13}$ The total revenues for the UAC totaled $\$ 1,019,000$ for the 2018/19 season.
} 
pirically when centers change methods. It is likely efficient for centers to have freedom in choosing their methods given that the users of a center's forecasting services are principals through the non-profit, so they can tailor their products to the needs of their communities. This can be explored empirically comparing across countries that vary in centralization of avalanche warning services.

\subsection{Conclusion}

The CAIC extending their daily forecasting operations into May in 2019 prevented roughly 5.5 incidents on considerable danger days. Historically, in April and May in Colorado the portion of avalanche incidents that resulted in serious accidents is right at $15 \%$. This translates to .8 fewer accidents across Colorado as a result of this extended forecasting season. This is partly counteracted by an increase on incidents occurring of low danger days, but the net effect is 3.4 fewer incidents during this time.

This decreased accident rate resulting from forecasting services suggests that access to additional information about a risky behavior reduces incidents and outweighs any effects from any sort of pseudo moral hazard or adverse selection. The CAIC achieved their desired outcome of reducing incidents by offering additional forecasting services. However, the increase in incidents on low danger days warrants further research when individual level data can be utilized. One of the main hindrances to using data from this unique setting is the selection into reporting. It should be restated that the results should all be interpreted as conditional on reporting by backcountry users.

Avalanche forecasting services have significant impacts on outcomes. The estimates here come from time periods when avalanche conditions are at their safest during the year, and yet this program still reduces accidents on net. It is important to note that the ideal incident rate is likely not zero. Accidentally triggering a slide is sometimes unavoidable in the backcountry. Outcomes can drastically differ, however, depending on the choices made by that individual. Forecasters want to discourage people from being below the danger, not on top of it. These results suggest that providing people with additional information about risks allows them to optimize accordingly to improve outcomes 
Figure 2.10: An example bulletin from the UAC

\section{Forecast for the Salt Lake Area Mountains}

Issued by Greg Gagne for Wednesday, February 13, 2019 - 3:57am

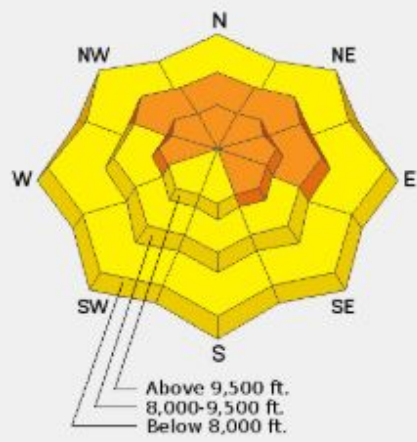

It is a day of rising danger, with the avalanche hazard reaching CONSIDERABLE by this afternoon at mid and upper elevations facing west, through north, and east. The primary avalanche concern are recent and new wind slabs at the mid and upper elevations. Cornices are also growing and may break off naturally. Avoid traveling on a slope beneath cornices, and stay well back from a corniced ridgeline. Possible rain on snow at lower elevations add to the list of avalanche concerns, as well as sluffing in the new snow and shallow, sensitive storm slabs that may develop during any period of higher precipitation intensity.

The avalanche hazard will likely rise to HIGH by later this week, with elevated avalanche hazard through at least the holiday weekend.

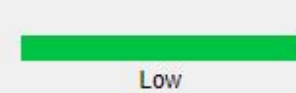

Moderate

without reliance on negative incentives.

\section{$2.7 \quad$ Appendix}


Figure 2.11: An example bulletin from the CAIC

\section{co. Colorado Avalanche}

Backcountry Avalanche Forecast

Sawatch Range

Thu, Jan 24, 2019 at 6:45 AM Issued by: Ben Pritchett

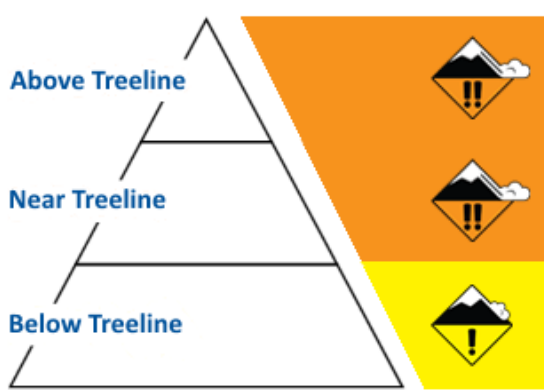

Danger Scale
Today

Considerable (3) Dangerous avalanche conditions. Cautious route-finding and conservative decision-making essential.

Considerable (3) Dangerous avalanche conditions. Cautious route-finding and conservative decision-making essential.

Moderate (2) Heightened avalanche conditions on specific terrain features. Evaluate snow and terrain carefully.
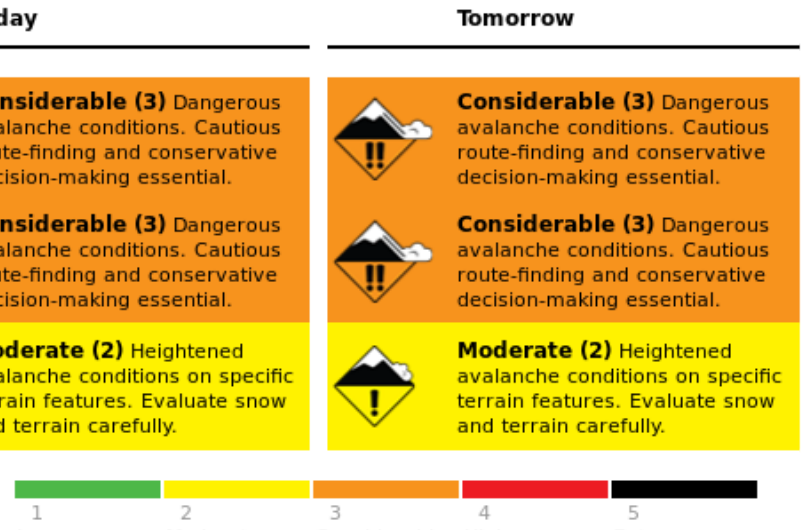

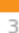

4

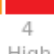

No Rating

Moderate

5 Extreme

Summary

Recent snowfall and steady northwest winds continue to load buried weak layers creating lingering dangerous avalanche conditions. Backcountry travelers can easily trigger large and potentially deadly avalanches on slopes below corniced ridgelines, steep rollovers in open areas, and the drifted sides of gullies. If you trigger an avalanche in the freshly drifted snow it may step down into older weak layers entraining much more snow and gathering more destructive force. Avalanches will be largest and most dangerous on northeast through east to southeast-facing aspects where the slabs are thickest.

Even in wind-sheltered terrain, consider that you can trigger avalanches remotely, or from far away. A group of skiers triggered two large avalanches breaking a couple feet deep near Cottonwood Pass on Wednesday on northerly terrain near treeline. The simplest approach right now is to stick to slopes less than about 30 degrees, without steeper terrain overhead.

Weather Forecast for 11,000ft

Issued Thursday, Jan 24, 2019 at 6:45 AM by Ben Pritchett

\begin{tabular}{|c|}
\hline Temperature $\left({ }^{\circ} \mathrm{F}\right)$ \\
\hline Wind Speed (mph) \\
\hline Wind Direction \\
\hline Sky Cover \\
\hline
\end{tabular}

\begin{tabular}{l} 
Thursday \\
\hline 28 to 33 \\
\hline 15 to 25 \\
\hline WSW \\
\hline Mostly Cloudy \\
\hline 2 to 4
\end{tabular}

\begin{tabular}{l} 
Thursday Night \\
\hline 15 to 20 \\
\hline 7 to 17 \\
\hline WSW \\
\hline Partly Cloudy \\
\hline 0 to 1
\end{tabular}

\begin{tabular}{l}
$\frac{\text { Friday }}{32 \text { to } 37}$ \\
\hline 12 to 22 \\
\hline WSW \\
\hline Mostly Cloudy \\
\hline 0 to 1 \\
\hline
\end{tabular}

Avalanche conditions can change rapidly during snow storms, wind storms, or rapid temperature change. For the most current information, go to www.colorado.govlavalanche.

(c) 2008-2018 Colorado Avalanche Information Center. All rights reserved. 
Figure 2.12: A sample (high quality) publicly submitted field report to the CAIC website
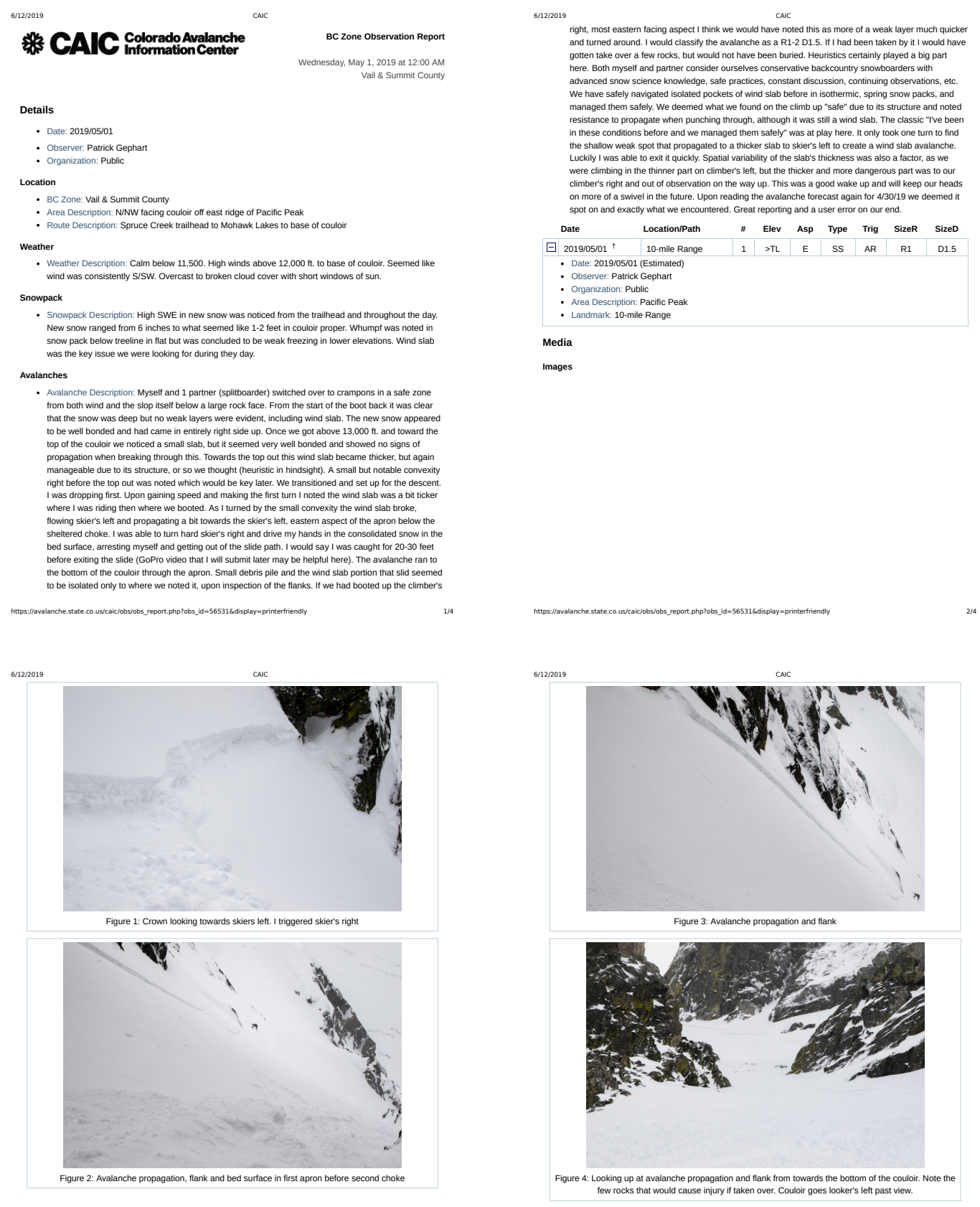
Table 2.5: Weather Control Variables Selected by Elastic Net Procedure

\begin{tabular}{|c|c|c|}
\hline & Variable & Coefficient \\
\hline 2 & tempav & -0.00083 \\
\hline 3 & precipincriment_snowadj & 0.16659 \\
\hline 4 & snowdepth & 0.00349 \\
\hline 5 & snowdensity & -0.00146 \\
\hline 6 & tempmin_sq & 0.00001 \\
\hline 7 & temphigh:tempmin & -0.00006 \\
\hline 8 & tempmin:snowfall & 0.00068 \\
\hline 9 & tempmin:precipincriment_snowadj & 0.01077 \\
\hline 10 & tempmin:snowdepth & 0.00009 \\
\hline 11 & snowfall:snowdepth & 0.00022 \\
\hline 12 & snowfall:tempav_sq & -0.00000 \\
\hline 13 & snowfall:temphigh_sq & -0.00000 \\
\hline 14 & snowfall:precipaccum_sq & -0.00000 \\
\hline 15 & snowfall:snowdepth_sq & -0.00000 \\
\hline 16 & snowfall:snowdensity_sq & -0.00000 \\
\hline 17 & precipincriment_snowadj:snowdepth & 0.00418 \\
\hline 18 & precipincriment_snowadj:tempav_sq & -0.00006 \\
\hline 19 & precipincriment_snowadj:temphigh_sq & -0.00014 \\
\hline 20 & precipincriment_snowadj:precipincriment_snowadj_sq & -0.00200 \\
\hline 21 & precipincriment_snowadj:precipaccum_sq & -0.00005 \\
\hline 22 & precipincriment_snowadj:snowdepth_sq & -0.00004 \\
\hline 23 & precipaccum:snowdepth & -0.00002 \\
\hline 24 & precipaccum:snowdepth_sq & -0.00000 \\
\hline 25 & snowdepth:tempmin sq & 0.00000 \\
\hline 26 & snowdepth:snowdepth_sq & -0.00000 \\
\hline 27 & swe:tempav_sq & -0.00000 \\
\hline 28 & swe:temphigh_sq & -0.00000 \\
\hline 29 & snowdensity:snowdensity_sq & 0.00000 \\
\hline 30 & tempav_sq:tempmin_sq & 0.00000 \\
\hline 31 & temphigh_sq:precipincriment_snowadj_sq & 0.00003 \\
\hline 32 & temphigh_sq:snowdensity_sq & 0.00000 \\
\hline 33 & tempmin_sq:precipincriment_snowadj_sq & -0.00006 \\
\hline 34 & tempmin_sq:precipaccum_sq- & -0.00000 \\
\hline 35 & tempmin_sq:swe_sq & -0.00000 \\
\hline 36 & snowfall_sq:snowdensity_sq & -0.00000 \\
\hline 37 & precipincriment_snowadj_sq:precipaccum_sq & 0.00005 \\
\hline 38 & precipincriment_snowadj_sq:snowdensity_sq & -0.00007 \\
\hline 39 & precipaccum_sq:snowdensity_sq & 0.00000 \\
\hline 40 & swe_sq:snowdensity_sq & 0.00000 \\
\hline
\end{tabular}


Table 2.6: Weather Control Variables Selected by LASSO Procedure

\begin{tabular}{|c|c|c|}
\hline & Variable & Coefficient \\
\hline 2 & tempav & -0.00071 \\
\hline 3 & precipincriment snowadj & 0.15617 \\
\hline 4 & snowdepth & 0.00368 \\
\hline 5 & snowdensity & -0.00167 \\
\hline 6 & tempmin_sq & 0.00001 \\
\hline 7 & temphigh:tempmin & -0.00007 \\
\hline 8 & tempmin:snowfall & 0.00071 \\
\hline 9 & tempmin:precipincriment_snowadj & 0.01095 \\
\hline 10 & tempmin:snowdepth & 0.00009 \\
\hline 11 & snowfall:snowdepth & 0.00021 \\
\hline 12 & snowfall:tempav_sq & -0.00000 \\
\hline 13 & snowfall:temphigh_sq & -0.00000 \\
\hline 14 & snowfall:precipaccum_sq & -0.00000 \\
\hline 15 & snowfall:snowdepth_sq & -0.00000 \\
\hline 16 & snowfall:snowdensity_sq & -0.00000 \\
\hline 17 & precipincriment_snowadj:snowdepth & 0.00466 \\
\hline 18 & precipincriment_snowadj:tempav_sq & -0.00003 \\
\hline 19 & precipincriment_snowadj:temphigh_sq & -0.00016 \\
\hline 20 & precipincriment_snowadj:precipincriment_snowadj_sq & -0.00265 \\
\hline 21 & precipincriment_snowadj:precipaccum_sq & -0.00006 \\
\hline 22 & precipincriment_snowadj:snowdepth_sq & -0.00004 \\
\hline 23 & precipaccum:snowdepth & -0.00002 \\
\hline 24 & precipaccum:temphigh_sq & 0.00000 \\
\hline 25 & precipaccum:snowdepth_sq & -0.00000 \\
\hline 26 & snowdepth:tempmin_sq & 0.00000 \\
\hline 27 & snowdepth:snowdepth_sq & -0.00000 \\
\hline 28 & swe:tempav_sq & -0.00000 \\
\hline 29 & swe:temphigh_sq & -0.00000 \\
\hline 30 & snowdensity:snowdensity_sq & 0.00000 \\
\hline 31 & tempav_sq:tempmin_sq & 0.00000 \\
\hline 32 & temphigh_sq:precipincriment_snowadj_sq & 0.00004 \\
\hline 33 & temphigh_sq:precipaccum_sq & 0.00000 \\
\hline 34 & temphigh_sq:snowdensity_sq & 0.00000 \\
\hline 35 & tempmin_sq:precipincriment_snowadj_sq & -0.00007 \\
\hline 36 & tempmin_sq:precipaccum_sq & -0.00000 \\
\hline 37 & tempmin_sq:swe_sq & -0.00000 \\
\hline 38 & snowfall_sq:snowdensity_sq & -0.00000 \\
\hline 39 & precipincriment_snowadj_sq:precipaccum_sq & 0.00005 \\
\hline 40 & precipincriment_snowadj_sq:snowdensity_sq & -0.00008 \\
\hline 41 & precipaccum_sq:snowdensity_sq & 0.00000 \\
\hline 42 & swe_sq:snowdensity_sq & 0.00000 \\
\hline
\end{tabular}


Table 2.7: Difference Model with level and Lasso selected controls

\begin{tabular}{|c|c|c|c|c|c|c|}
\hline & \multicolumn{6}{|c|}{ Dependent variable: } \\
\hline & \multicolumn{6}{|c|}{ Incidents } \\
\hline & $(1)$ & $(2)$ & $(3)$ & $(4)$ & $(5)$ & $(6)$ \\
\hline Low CO Extension & $\begin{array}{c}0.031^{* *} \\
(0.014)\end{array}$ & $\begin{array}{l}0.038^{*} \\
(0.023)\end{array}$ & $\begin{array}{l}0.039^{*} \\
(0.022)\end{array}$ & $\begin{array}{c}0.053^{* * *} \\
(0.017)\end{array}$ & $\begin{array}{c}0.050^{* * *} \\
(0.019)\end{array}$ & $\begin{array}{l}0.033^{*} \\
(0.018)\end{array}$ \\
\hline Moderate CO Extension & $\begin{array}{l}-0.039 \\
(0.025)\end{array}$ & $\begin{array}{l}-0.006 \\
(0.010)\end{array}$ & $\begin{array}{c}0.006 \\
(0.015)\end{array}$ & $\begin{array}{l}-0.010 \\
(0.023)\end{array}$ & $\begin{array}{c}0.015 \\
(0.017)\end{array}$ & $\begin{array}{c}0.010 \\
(0.017)\end{array}$ \\
\hline Considerable CO Extension & $\begin{array}{c}-0.138^{* *} \\
(0.066)\end{array}$ & $\begin{array}{c}-0.084^{* *} \\
(0.035)\end{array}$ & $\begin{array}{c}-0.069^{* *} \\
(0.034)\end{array}$ & $\begin{array}{c}-0.156^{* *} \\
(0.076)\end{array}$ & $\begin{array}{c}-0.105^{* *} \\
(0.049)\end{array}$ & $\begin{array}{c}-0.103^{* *} \\
(0.050)\end{array}$ \\
\hline Zone x Season FEs & - & $\mathrm{Y}$ & $\mathrm{Y}$ & - & $\mathrm{Y}$ & $\mathrm{Y}$ \\
\hline Day of Week and Month FEs & - & - & $\mathrm{Y}$ & - & - & $\mathrm{Y}$ \\
\hline Weather Controls & Level & Level & Level & Lasso & Lasso & Lasso \\
\hline Observations & 17,638 & 17,638 & 17,638 & 17,635 & 17,635 & 17,635 \\
\hline $\mathrm{R}^{2}$ & 0.045 & 0.121 & 0.124 & 0.052 & 0.128 & 0.130 \\
\hline Adjusted $\mathrm{R}^{2}$ & 0.043 & 0.115 & 0.118 & 0.049 & 0.121 & 0.123 \\
\hline Residual Std. Error & 0.475 & 0.457 & 0.456 & 0.474 & 0.456 & 0.455 \\
\hline
\end{tabular}

Table 2.8: Poisson Models of DiD Estimator

\begin{tabular}{|c|c|c|c|c|c|c|}
\hline & \multicolumn{6}{|c|}{ Dependent variable: } \\
\hline & \multicolumn{6}{|c|}{ Incidents } \\
\hline & $(1)$ & $(2)$ & $(3)$ & $(4)$ & $(5)$ & $(6)$ \\
\hline Low CO Extension & $\begin{array}{c}0.215 \\
(0.139)\end{array}$ & $\begin{array}{c}0.046 \\
(0.032)\end{array}$ & $\begin{array}{c}0.053 \\
(0.038)\end{array}$ & $\begin{array}{l}0.207^{* *} \\
(0.103)\end{array}$ & $\begin{array}{c}0.041^{*} \\
(0.015)\end{array}$ & $\begin{array}{c}0.036^{* *} \\
(0.018)\end{array}$ \\
\hline Moderate CO Extension & $\begin{array}{l}-0.016 \\
(0.018)\end{array}$ & $\begin{array}{c}0.0005 \\
(0.005)\end{array}$ & $\begin{array}{c}0.005 \\
(0.008)\end{array}$ & $\begin{array}{c}0.004 \\
(0.018)\end{array}$ & $\begin{array}{c}0.003 \\
(0.004)\end{array}$ & $\begin{array}{c}0.003 \\
(0.005)\end{array}$ \\
\hline Considerable CO Extension & $\begin{array}{c}-0.043^{* * *} \\
(0.010)\end{array}$ & $\begin{array}{c}-0.006^{* * *} \\
(0.002) \\
\end{array}$ & $\begin{array}{l}-0.003 \\
(0.004) \\
\end{array}$ & $\begin{array}{c}-0.039^{* * *} \\
(0.007)\end{array}$ & $\begin{array}{c}-0.008^{* * *} \\
(0.001) \\
\end{array}$ & $\begin{array}{c}-0.008^{* * *} \\
(0.002) \\
\end{array}$ \\
\hline Zone x Season FEs & - & $\mathrm{Y}$ & $\mathrm{Y}$ & - & $\mathrm{Y}$ & $\mathrm{Y}$ \\
\hline Day of Week and Month FEs & - & - & $\mathrm{Y}$ & - & - & $\mathrm{Y}$ \\
\hline Weather Controls & Level & Level & Level & Lasso & Lasso & Lasso \\
\hline $\mathrm{N}$ & 17,638 & 17,638 & 17,638 & 17,635 & 17,635 & 17,635 \\
\hline $\mathrm{AIC}$ & $11,448.570$ & $9,791.459$ & $9,691.798$ & $11,136.990$ & $9,602.483$ & $9,521.585$ \\
\hline
\end{tabular}


Table 2.9: Negative Binomial Models of DiD

\begin{tabular}{|c|c|c|c|c|c|c|}
\hline & \multicolumn{6}{|c|}{ Dependent variable: } \\
\hline & \multicolumn{6}{|c|}{ Incidents } \\
\hline & $(1)$ & $(2)$ & $(3)$ & $(4)$ & $(5)$ & $(6)$ \\
\hline Low CO Extension & $\begin{array}{c}0.236 \\
(0.144)\end{array}$ & $\begin{array}{c}0.011 \\
(0.008)\end{array}$ & $\begin{array}{c}0.015 \\
(0.011)\end{array}$ & $\begin{array}{c}0.308^{* * *} \\
(0.096)\end{array}$ & $\begin{array}{c}0.013^{* * *} \\
(0.005)\end{array}$ & $\begin{array}{c}0.012^{* *} \\
(0.006)\end{array}$ \\
\hline Moderate CO Extension & $\begin{array}{c}-0.012 \\
(0.019)\end{array}$ & $\begin{array}{l}0.0004 \\
(0.001)\end{array}$ & $\begin{array}{c}0.002 \\
(0.002)\end{array}$ & $\begin{array}{c}0.008 \\
(0.018)\end{array}$ & $\begin{array}{c}0.001 \\
(0.001)\end{array}$ & $\begin{array}{c}0.002 \\
(0.002)\end{array}$ \\
\hline Considerable CO Extension & $\begin{array}{c}-0.040^{* * *} \\
(0.011)\end{array}$ & $\begin{array}{l}-0.001 \\
(0.001) \\
\end{array}$ & $\begin{array}{l}0.0003 \\
(0.002) \\
\end{array}$ & $\begin{array}{c}-0.035^{* * *} \\
(0.008) \\
\end{array}$ & $\begin{array}{c}-0.001^{* *} \\
(0.001) \\
\end{array}$ & $\begin{array}{l}-0.001 \\
(0.001) \\
\end{array}$ \\
\hline Zone x Season FEs & - & $\mathrm{Y}$ & $\mathrm{Y}$ & - & $\mathrm{Y}$ & $\mathrm{Y}$ \\
\hline Day of Week and Month FEs & - & - & $\mathrm{Y}$ & - & - & $\mathrm{Y}$ \\
\hline Weather Controls & Level & Level & Level & Lasso & Lasso & Lasso \\
\hline $\mathrm{N}$ & 17,638 & 17,638 & 17,638 & 17,635 & 17,635 & 17,635 \\
\hline $\mathrm{AIC}$ & $10,091.860$ & $9,151.342$ & $9,086.934$ & $9,970.340$ & $9,089.528$ & $9,036.260$ \\
\hline
\end{tabular}




\section{Chapter 3}

\section{Beat Cops and Beat Reporters: The impact of local press on taxation by citation}

\section{$3.1 \quad$ Introduction}

Municipal governments are increasingly using the judiciary to increase revenue. A 2019 report found more than 600 municipalities in the United States that raised more than 10 percent of general fund revenues from police issued fines and forfeitures (Maciag, 2019). There is a strong sentiment that maximizing roadway safety is not the only determinant in traffic enforcement. The interactions of law enforcement with the citizenry has received more attention with the growth of social media than any other time in American history. While interactions with police may bring to mind viral videos and cable news reports, this role has been filled by traditional print media outlets for much longer in many American towns. Local reporters acted as a monitoring mechanism between the police and general public before the internet, and I argue they still do.

This paper investigates what impact the presence of local print media has on the everyday operations of law enforcement agencies using data from routine traffic stops. Print media provides feedback to the community on the operations of their law enforcement agencies increasing the observability of the principal (the voters) over the agent (the law enforcement). When a newspaper closes down, the 
law enforcement activity may decrease because of shirking as the ability for voters to monitor has weakened.

Incentives to shirk may be overpowered by bureaucratic motives. Activity may increase if the law enforcement agencies are pressured to increase 'taxation by citation' activities. Evidence from California shows that fines per capita increase in years after tax revenue decreases ( $\mathrm{Su}, 2020)$. Revenue from citations could be increased through higher fees or increased ticketing, dependent on the elasticity of fines. The politicians that departments are accountable may feel constrained in their ability to raise revenues through citations when a local print media outlet is closely reporting on the activities of the politicians, police, and courts. The removal of newspaper coverage could increase police activity through fewer constraints on politicians and bureaucrats.

I use data from over 10 million traffic stops in Illinois to test the impact of local press on police activity. I use the closings of two newspapers in rural Illinois counties and difference-in-difference models which suggest that a driver is around 5 percent more likely to receive a ticket after the newspaper closes and more likely to be searched. Aggregated models suggest this effect leads to more stops and roughly one additional ticket per day for a small town police or sheriff department. Minor infractions such as equipment violations and expired registration see a disproportional increase after newspaper closure.

To further investigate the distribution of this change in ticketing behavior, I use vehicle registration information to determine the residency of the driver stopped. The population most served by the newspaper reporting would be the readers or residents in the newspaper's distribution and political district. I compare changes in law enforcement traffic stops among residents and non-residents when the newspaper closes. If the local newspaper is constraining traffic citations by law enforcement officers, then I expect that benefit to be concentrated in residents, while non-residents will be less affected. Using triple difference models, I find that the resident discount ${ }^{1}$ is reduced by almost 50 percent when a small town newspaper closes. The increase in aggregate ticketing largely accrues to locals, who receive nearly 80 percent of the increase in tickets issued after newspaper exit. This

\footnotetext{
${ }^{1}$ I use the resident discount to refer to the average difference in ticketing rates, condition on stopped, between residents and non-residents.
} 
causal result suggests that there is some mechanism in local press that constrains ticketing by law enforcement.

This paper contributes by merging these two substantive literatures on political factors affecting policing as well as media and governance. The results show one mechanism, from print media to police, that non-safety maximizing incentives affect law enforcement. By using data on all traffic stops, not just stops resulting in citations, I am able to explore on what margins bureaucratic incentives alter the law enforcement officers decision whether at the stop decision or the ticket decision. Second, these results extend the literature on press and government accountability to non-elected officials. The current empirical literature is concentrated on large decisions elected officials have discretion over, such as budgeting. These results show how these incentives work down to lower levels of government and affect everyday decisions of rank and file officials such as police officers conducting traffic stops.

\subsection{Policing, Press, and Political Accountability}

Theory suggests that optimal enforcement and punishment is based on the marginal increase public safety versus the harm posed by the offender (Becker, 1968; Ehrlich, 1996) and that the optimal fine should include the variable enforcement costs (Polinsky and Shavell, 1992). Empirical evidence shows that crime, or in the case here traffic incidents, do respond negatively to increased levels of enforcement (DeAngelo and Hansen, 2014; Luca, 2015; Makowsky and Stratmann, 2011). The increases in roadway safety are due to safer driving because increased enforcement reduces recidivism by drivers (Gehrsitz, 2017; Goncalves and Mello, 2017). Maximizing safety may not be the only objective in enforcement decisions however, and there is growing evidence about the additional public and private incentives which may determine traffic enforcement.

There is a large and growing literature about the concerning racial disparities in the application of the law in the United States. Particularly pertaining to traffic stops, racial bias in policing can be a determinant of traffic stop outcomes for individuals (Antonovics and Knight, 2009; Anwar and 
Fang, 2006; Quintanar, 2017). Goncalves and Mello (2018) find that a minority of officers can explain disparities in outcomes based on race. Beyond discrimination by individual officers, traffic stops may be conducted to directly garner funds through civil asset forfeiture programs (Baicker and Jacobson, 2007). This practice of 'policing for profit' can also occur indirectly.

Municipalities can raise revenues indirectly through taxation by citation such as issuing parking fines, code violations, and driving violations. Anecdotal stories abound across the country from drivers with out of state plates being warned to watch their speed in a specific town, or Florida State Highway Patrol ticketing north bound traffic to avoid fining vacationers on the way into the state. Often the suspicion is that local officials encourage these enforcement strategies to raise revenues. This has lead to a community efforts such as Doraville Georgia, where residents filed a lawsuit against the city for raising too much of the city's general funds from police and court activities (Wilson, 2018). ${ }^{2}$ This lawsuit is not an isolated incident and organizations support efforts to push back on taxation by citation through court and legislative action. The Fines and Fees Justice Center is one such organization working in this area and it reports being involved in 85 law suits and 78 pieces of legislation across the United States involving fines and fees.

Empirical research supports these community concerns about governments relying on revenue from the judicial system (Su, 2020). Garrett and Wagner (2009) show that fiscal deficits can lead to more traffic citations to generate revenue. They use annual panel data from North Carolina to find an elasticity of 10 percent revenue decline increasing traffic ticket growth by over 6 percent. Consistent with the ratchet effect of bureaucratic budget maximizers, ticketing does not decrease in years following revenue growth. Makowsky and Stratmann (2009) further this literature by establishing causality and show that out of town drivers are more likely to be ticketed. They explore how the ability to vote in local elections affects police behavior. Using data from nearly 70,000 traffic tickets and warnings in Massachusetts over a three month period in 2001, they compare outcomes for residents of the municipality to residents outside the municipality. They find that local drivers are less likely to be ticketed and pay a lower fine when ticketed. This finding is consistent with their view

\footnotetext{
${ }^{2} 24$ percent of the Doraville budget was raised from fees.
} 
that since non-local drivers cannot vote in local elections, municipalities engage in tax exporting by raising revenues from non-voters.

Newspaper circulation has been on the decline in America for the past 3 decades (Barthel, 2017), particularly hard hit are outlets with smaller markets. Combined with the belief that a free and independent press is necessary for a properly functioning democracy, there is a growing concern about bad outcome from these 'news deserts,' areas that lack a newspaper outlet. Affected communities lose the 'watch-dog' role that print news media have over numerous organizations. The newspaper serves as an outlet for the whistle blower or the investigative reporter, such as corporate fraud cases (Dyck, Morse, and Zingales, 2010). In addition to private organizations, the newspaper's watch-dog role also extends to democratic government.

It is a common belief that a free press is a necessary condition for a functioning democracy. The press provides information to voters allowing them to cast more informed ballots. Mondak (1995) uses a newspaper strike in Pittsburgh, PA, showing a decrease in voters perceived information about local politics, however little effect for national politics. Newspapers exiting markets also can also lead to lower voter turnout, though an increase in the number of newspaper outlets circulating does not increase voter involvement (Gentzkow, Shapiro, and Sinkinson, 2011).

If newspaper circulation is affecting voter participation and shifting the median voter, it should have an impact on the behavior of politicians either running for office or how they perform their duties in office. At the federal level, Snyder Jr and Strömberg (2010) show that congressional representatives from districts with less newspaper coverage are less likely to attend hearings or work for legislation to benefit their district. However this does not show how newspaper coverage translates into real outcomes for people. Evidence from Japan suggests that markets with less newspaper competition receive fewer funds for projects (Yazaki, 2017), but the efficacy of these projects is not covered. This literature is supportive of the hypothesis that newspaper closure would increase shirking by local officials and lead to a decrease in police activity.

Gao, Lee, and Murphy (2018) examine borrowing costs for a municipality, finding a 5-11 basis point increases in interest rates after a newspaper closes. Since informational efficiency in the 
bond market should lead to different borrowing costs and credit ratings for more or less efficient governments, they are using the interest rate a local government must pay as a proxy for government performance. They rely on the expansion of Craigslist, which reduces a newspapers revenues from classifieds and increases the likelihood of closing, as their instrument to handle prevailing economic performance confounding their results. Ultimately higher borrowing costs for a municipality must be made up for in revenues from taxation, suggesting that newspaper closings does lead to worse outcomes for citizens.

The impact of newspaper coverage on elected officials is not confined to the legislative or executive branches. Lim, Snyder Jr, and Strömberg (2015) match newspaper distribution markets with judicial election districts and find that elected judges change sentences based on newspaper coverage. Their effects are stronger in districts where judges run in non-partisan elections, arguing that voters rely more on news coverage to form beliefs about candidates in absence of political parties. Judges increase sentence lengths to pander to voters desire for increased penalties for crime, and violent crimes receive the largest net increases the more a judge appears in the paper.

If judges are responsive to press coverage, it is not a far off assumption that effects will extend further into the criminal justice system and law enforcement. Incumbent sheriffs adjust traffic stop ticketing behavior when re-election season rolls around, giving likely voters a break on citations (Ferrell, Matti, and McCannon, 2019). Subtle incentives adjust the strategies used to distribute justice, and newspaper coverage can have a similar affect.

Criminal actors use murders of journalist to enforce and maintain corrupt deals (Bjørnskov and Freytag, 2016). This suggests that bad actors are concerned about the 'watch-dog' power of the press and act accordingly. When there is no media presence, that is one less concern for criminal actors attempting to use bribery and the government official that is the recipient of the bribe. Incentives for law enforcement to pursue some strategy other than pure safety maximization may be more likely to develop and persist longer when there is no local press coverage.

The 'watch-dog' role of the newspaper may constrain the issuance of tickets for revenue generation. If the media coverage is actively preventing taxation-by-citation then law enforcement activity should 
increase after the event of a newspaper shutdown. By looking at an instance where media is removed, I am able to add to the literature on media's role in institutional change. Coyne and Leeson (2009) lay out a theory where media induces change in institutional equilibrium through three phases, gradual, punctuation, and reinforcement. Decreases in law enforcement behavior would suggest movement along the third phases, with reduced ability of the local media to reinforce institutional equilibria. Increases in law enforcement behavior could suggest a move towards new equilibria, if these increases are being pushed by budget maximizing bureaucrats who feel they are operating under a new set of constraints.

\subsection{Stop Data and Newspaper Closures}

There are two main margins for officer discretion when conducting a routine traffic stop. First, a police officer must observe something to give probable cause to initiate a traffic stop. This can occur from seeing a moving violation like rolling a stop sign, clocking someone speeding, equipment and registration issues, or other information. After observing reason to initiate a stop, then officers decide whether or not they will actually conduct a traffic stop. During the stop, the officer then makes a decision on what course of action to take, such as issuing a formal citation, warning, or initiating a search or arrest if more criminal behavior is observed.

Given the growing concerns about racial bias, Illinois Senate Bill 30 established a statewide data collection program on traffic stops in 2003 (Illinois Traffic and Pedestrian Stop Study). This program was set to expire after 4 years initially, but it has been extended into perpetuity. This program requires all officers to fill out a form every time they conduct a traffic stop, regardless of outcome. All Illinois State Troopers, sheriff departments, and police departments in municipalities with sufficient size participate. There are 102 counties in Illinois, each with a sheriffs office that report stops and roughly 300 Police Departments that report. The full data set contains all traffic stops from 2011 to 2018 by sheriff deputies and police officers that are reported. All data from Cook County (Chicago) is removed as well as university and hospital police departments. All state level departments are 
dropped from the sample as well. This leaves information on 7,434,598 traffic stops to be used for analysis. The data includes information about the driver and details of the stop, as well as the vehicle make and year plus the zip code the vehicle is registered in. These details filled out by the officer conducting the stop include the time of day and date, reason for the stop, if a search was conducted, and the outcome of the stop. The possible outcomes are recorded as no action, warning, or citation. In the original data the outcome of an individual stop is separated by drivers and passengers. The demographic data contain information on race, sex, and age. Controlling for this information is important because of a growing literature that displays disparities in stop outcomes based on driver characteristics (Antonovics and Knight, 2009; Anwar and Fang, 2006; Quintanar, 2017).

I report the individual stop summary statistics in Table 3.1. Stops by police departments make up 82 percent of the sample, with the remaining being conducted by sheriff deputies. I exclude state level organizations because of differences in reporting districts. ${ }^{3} 43$ percent of stops result in a ticket and just under 5 percent of stops involve a search of some kind. The majority of people stopped are white and the average age is around 36. Moving violations make up 69 percent of stops, with speeding being the most frequent moving violation. Other moving violations include lane violations, seat belt use, not stopping for a traffic sign, and following too close. 71 percent of vehicles stopped are driven by residents.

Table 3.2 shows the summary statistics for the stop data aggregated at the department and month level. The average department conducts around 138 stops per month, writing 60 tickets and conducting between 6 and 7 searches.

This stop program provides one distinct advantage over data used in the previous literature. Studies such as Makowsky and Stratmann (2009) use data from speeding tickets specifically, so they only observe stops that result in a formal citation. This means the data generating process is censored at the decision to issue a ticket. Because the Illinois Traffic Stop Study requires officers to $\log$ every stop, it provides a more complete picture including stops that result in a warning. It is still censored at the decision to initiate a stop because the universe of vehicles that are not pulled over

\footnotetext{
${ }^{3}$ While Illinois State Police would make an ideal control group for empirical analysis, they do not report geographic location or district in the stop data so I cannot compare traffic stop outcomes to their local counterparts.
} 
Table 3.1: Individual Stop Summary Statistics

\begin{tabular}{lcc}
\hline \hline Statistic & $\mathrm{N}$ & Mean \\
\hline Sheriff & $1,317,969$ & 0.177 \\
Police & $6,116,629$ & 0.823 \\
Ticket & $3,216,073$ & 0.433 \\
Warning & $4,218,524$ & 0.567 \\
Search & 363,588 & 0.049 \\
White & $5,276,976$ & 0.710 \\
Black & $1,092,038$ & 0.147 \\
Hispanic & 858,713 & 0.116 \\
Other & 718,366 & 0.097 \\
Age & - & 36.602 \\
Female & $2,970,073$ & 0.399 \\
Moving viol & $5,133,396$ & 0.690 \\
Equip viol & $1,406,991$ & 0.189 \\
License reg & 875,211 & 0.118 \\
Commercial Vehicle & 19,000 & 0.003 \\
Speed & $2,967,101$ & 0.399 \\
Lane Violation & 443,762 & 0.060 \\
Seatbelt & 199,856 & 0.027 \\
Traffic sign & 802,318 & 0.108 \\
Follow close & 23,135 & 0.003 \\
Resident & $5,330,764$ & 0.717 \\
\hline
\end{tabular}

Table 3.2: Department Monthly Summary Statistics

\begin{tabular}{lcccccc}
\hline \hline Statistic & Mean & St. Dev. & Min & Pctl(25) & Pctl(75) & Max \\
\hline Stops & 138.785 & 241.054 & 1 & 11 & 156 & 4,295 \\
Warning & 78.749 & 155.733 & 0 & 3 & 82 & 3,179 \\
Tickets & 60.036 & 110.399 & 0 & 5 & 63 & 1,736 \\
Searches & 6.787 & 21.643 & 0 & 0 & 4 & 446 \\
Black & 20.386 & 55.059 & 0 & 0 & 14 & 989 \\
Other Race & 13.410 & 28.615 & 0 & 1 & 13 & 552 \\
White & 98.508 & 154.049 & 0 & 10 & 117 & 1,537 \\
Hispanic & 16.030 & 54.887 & 0 & 0 & 9 & 1,741 \\
Resident & 99.512 & 193.132 & 0 & 6 & 103 & 4,025 \\
Nonresident & 39.273 & 65.829 & 0 & 4 & 45 & 1,092 \\
\hline
\end{tabular}

is not observed, but it offers and improvement over previous sources. This more complete picture allows me to draw inferences along which margins officers are influenced whether it be quantity of stops or propensity to ticket given an individual stop.

To estimate the effect of newspapers on police behavior, I use the two newspapers that closed in southern Illinois. The Murphysboro Times in Murphysboro, Illinois, as well as The Daily American in West Frankfort both closed shop in May of 2015. These towns are in the neighboring counties of 
Jackson and Franklin, respectively.

\subsection{Empirical Results}

\subsubsection{Individual Stops}

I begin by estimating a difference-in-difference specification in Equation 3.1 for the outcome of stop $i$ by department $j$ on day $t$. The difference-in-difference variable of interest is Closure, which takes on a value of 1 after the Murphysboro Times and Daily American close for departments in the affected counties. $D_{i}$ includes individual stop level characteristics such as purpose and driver demographics, age, race, and gender. Agency and time fixed effects are included in $X$ and an error term. Standard errors are clustered on the agency and year.

$$
\text { ticket }_{i j t}=\alpha_{0}+\alpha_{1} \text { Closure }_{j t}+\alpha_{2} D_{i}+\alpha_{3} X_{j t}+\epsilon
$$

Table 3.3 shows a linear probability model for stop outcomes. Conditional on being stopped, individuals are around 7 percentage points more likely to receive a ticket after the newspaper closes, relative to the individuals stopped in jurisdictions where there was no change in press coverage, however this is not statistically significant. The probability of a search being conducted during a stop does increase by around 3 percentage points. This effect is statistically significant and suggestive that law enforcement officers behave more hawkish in absence of local newspaper coverage.

\subsubsection{Aggregated Stops}

To complete the picture of changes in traffic stops from press coverage, I aggregate the individual stop data to totals for departments by month and estimate a similar model with Equation 3.2. I regress the total number of stops conducted, tickets written, and searches conducted on the difference- 
Table 3.3: Individual Stop Level

\begin{tabular}{lcc}
\hline \hline & \multicolumn{2}{c}{ Dependent variable: } \\
\cline { 2 - 3 } & Ticket & Searched \\
& $(1)$ & $(2)$ \\
\hline Closure & 0.052 & $0.026^{* *}$ \\
& $(0.051)$ & $(0.012)$ \\
& & \\
\hline Stop/Demographics & & $\mathrm{Y}$ \\
YearxMonth FEs & $\mathrm{Y}$ & $\mathrm{Y}$ \\
Department FE & $\mathrm{Y}$ & $\mathrm{Y}$ \\
\hline Observations & $7,434,598$ & $7,434,598$ \\
$\mathrm{R}^{2}$ & 0.211 & 0.244 \\
Adjusted R & & 0.244 \\
Residual Std. Error $(\mathrm{df}=7433697)$ & 0.440 & 0.188 \\
\hline \hline Note: & $* \mathrm{p}<0.1 ;{ }^{* *} \mathrm{p}<0.05 ;{ }^{* * *} \mathrm{p}<0.01$
\end{tabular}

in-difference coefficient, Closure. The effect of the newspaper exit on aggregate activity appears to increase stops by 32 per month, leading to 23 additional tickets, but no significant effect on searches. Murphysboro and West Frankfort report having 16 and 13 full time officers currently. The estimated increase in tickets roughly averages out to a patrolman conducting 4 more stops and writing 3 additional tickets per month after the newspaper closing. ${ }^{4}$ There does not appear to be a significant effect on searches. It appears that officers both increase tickets and decrease leniency. The average ticket rate is below 50 percent, but 32 additional stops leading to 23 more tickets is well above this rate. However, that assumes that all the increase in tickets written results from stops that would not have been conducted if the newspaper was still circulating. To get a better picture of how the newspaper closure affects traffic stops, it is important to examine the why and to who these tickets accrue.

$$
\text { Outcome }_{j t}=\alpha_{0}+\alpha_{1} \text { NewspaperClose } \text { jt }_{t}+\alpha_{2} X_{j t}+\epsilon
$$

\footnotetext{
${ }^{4}$ This is assuming that the chief and detectives are not regularly conducting traffic stops.
} 
Table 3.4: Monthly totals

\begin{tabular}{|c|c|c|c|}
\hline & \multicolumn{3}{|c|}{ Dependent variable: } \\
\hline & Stops & Tickets & Searches \\
\hline & $(1)$ & $(2)$ & $(3)$ \\
\hline Closure & $\begin{array}{l}32.017^{* *} \\
(13.617) \\
\end{array}$ & $\begin{array}{c}23.265^{* * *} \\
(8.502)\end{array}$ & $\begin{array}{c}1.630 \\
(3.102)\end{array}$ \\
\hline YearxMonth FEs & $\mathrm{Y}$ & $\mathrm{Y}$ & $\mathrm{Y}$ \\
\hline Department FE & $\mathrm{Y}$ & $\mathrm{Y}$ & $\mathrm{Y}$ \\
\hline Observations & 53,569 & 53,569 & 53,569 \\
\hline $\mathrm{R}^{2}$ & 0.887 & 0.838 & 0.703 \\
\hline Adjusted $\mathrm{R}^{2}$ & 0.885 & 0.835 & 0.698 \\
\hline Residual Std. Error $(\mathrm{df}=52684)$ & 81.715 & 44.796 & 11.889 \\
\hline
\end{tabular}

\subsection{Residency Status}

The hypothesis of Makowsky and Stratmann (2009) suggests that when law enforcement engages in taxation by citation, tickets will be predominately written to out-of-town drivers. This is because voting residents can seek reprisal at the ballot box, while non-residents face a greater collective action cost requiring influence at the state level to push back. It follows then that residents and non-residents will be affected differently by the presence of newspaper coverage. Any protection from taxation by citation provided by the newspaper will more likely benefit residents. If this is true then after newspapers close, the ticketing rate of residents should increase, while non-residents should not be affected.

I use the zip code of the car registration to determine residency status of the driver and replicate Equation 3.1 with the residency status interacted with newspaper closure to test for differing effects between residents and non-residents. These results are presented in Table 3.5. The same controls for stop purpose and demographics, as well as fixed effects are included and standard errors are clustered on department and year.

The results in Table 3.5 show the differing effects for resident drivers after the closure. Residents are 3 percentage points more likely to receive a ticket and 1 percentage point more likely to be 
Table 3.5: Residency Status in Individual Stops

\begin{tabular}{lcc}
\hline \hline & \multicolumn{2}{c}{ Dependent variable: } \\
\cline { 2 - 3 } & Ticket & Search \\
& $(1)$ & $(2)$ \\
\hline Closure & 0.029 & $0.018^{*}$ \\
& $(0.058)$ & $(0.011)$ \\
Resident & $-0.010^{* * *}$ & 0.001 \\
& $(0.004)$ & $(0.001)$ \\
Closure:Resident & & \\
& $0.030^{* * *}$ & $0.010^{*}$ \\
\hline Stop/Demographics & $(0.010)$ & $(0.005)$ \\
YearxMonth FEs & & $\mathrm{Y}$ \\
Department FE & $\mathrm{Y}$ & $\mathrm{Y}$ \\
\hline Observations & $\mathrm{Y}$ & $\mathrm{Y}$ \\
$\mathrm{R}^{2}$ & $\mathrm{Y}$ & $7,434,598$ \\
Adjusted R & & 0.244 \\
Residual Std. Error $(\mathrm{df}=7433695)$ & 0.440 & 0.244 \\
\hline \hline Note: & ${ }^{*} \mathrm{p}<0.1 ;{ }^{* *} \mathrm{p}<0.05 ;{ }^{* * *} \mathrm{p}<0.01$ \\
& & 0.188 \\
\hline
\end{tabular}

searched, conditional on being stopped relative to non-resident drivers. This means a 7 percent increase in the probability of being ticketed and a 23 percent increase in the probability of being searched. There is a slight discount, only 1 percentage point, according to these results that residents receive on average. In the aggregate data, 48.47 percent of non-resident stops result in a ticket to 44.18 percent of resident stops, meaning newspaper closure reduces 68 percent of the naive difference in outcomes for residents vs non-residents.

To put this into context, consider the effect of residency on ticket outcomes from Table 3.9. Only including fixed effects in column 1 , the residency effect is similar to the aggregate data at 4.3 percent. However, this magnitude is dampened to less than one percentage point difference with the inclusion of demographic controls, and significance is erased entirely by including initial stop purpose as well. It is important to note that the explanatory power of all of these individual stop level models is poor, largely because some of the most important variables are latent. How egregious the violation that caused the stop is not observed, like how fast a driver was speeding, and stop characteristics like how a driver acted during the stop likely play a large role in explaining outcomes and these factors are 
probably not random across stops.

For robustness, I replicate the model in Table 3.5 with a true triple difference model. This includes fixed effects for department by time, and treating residents and non-residents separately. These results are reported in Table 3.10. The coefficient on residency status remains positive and significant in the triple difference models, though with slightly reduced magnitudes. Residents are 1.7 percentage points more likely to receive a ticket according to this specification, translating to a 4 percentage increase in ticketing. The triple difference model is a good robustness check because of the department by time fixed effects, however it is not my preferred specification. Identification in a triple difference model is based on a control group, in this case non-resident drivers, which are unaffected by the policy. I argue it is reasonable that resident drivers will be affected more but traffic stop outcomes being entirely unaffected by newspaper closure may be a strong assumption. That assertion is supported by the results discussed next in Table 3.6.

To develop a more complete picture of stop disparities, I return to the aggregated data in Table 3.6, identical to Table 3.4 except broken out by residency status. The results show nearly 27 additional stops per month of resident drivers, with an increase of more than 18 tickets. Law enforcement stops 5 more non-resident drivers, with an equivalent increase in tickets to those drivers. 
Table 3.6: Resident and Non-resident totals

\begin{tabular}{lcccccc}
\hline \hline & \multicolumn{3}{c}{ Resident: } & \multicolumn{3}{c}{ Non-resident: } \\
\cline { 2 - 6 } & Stops & Tickets & Searches & Stops & Tickets & Searches \\
& $(1)$ & $(2)$ & $(3)$ & $(4)$ & $(5)$ & $(6)$ \\
\hline Closure & $26.984^{* *}$ & $18.392^{* * *}$ & 1.733 & $5.033^{*}$ & $4.873^{* *}$ & -0.103 \\
& $(11.130)$ & $(6.450)$ & $(2.488)$ & $(2.922)$ & $(2.206)$ & $(0.632)$
\end{tabular}

\begin{tabular}{lcccccc}
\hline YearxMonth FEs & $\mathrm{Y}$ & $\mathrm{Y}$ & $\mathrm{Y}$ & $\mathrm{Y}$ & $\mathrm{Y}$ & $\mathrm{Y}$ \\
Department FE & $\mathrm{Y}$ & $\mathrm{Y}$ & $\mathrm{Y}$ & $\mathrm{Y}$ & $\mathrm{Y}$ & $\mathrm{Y}$ \\
\hline Observations & 53,569 & 53,569 & 53,569 & 53,569 & 53,569 & 53,569 \\
$\mathrm{R}^{2}$ & 0.898 & 0.857 & 0.723 & 0.819 & 0.764 & 0.592 \\
Adjusted $\mathrm{R}^{2}$ & 0.896 & 0.855 & 0.718 & 0.816 & 0.760 & 0.585 \\
Residual Std. Error $(\mathrm{df}=52684)$ & 62.255 & 31.822 & 9.442 & 28.202 & 20.869 & 3.539 \\
\hline \hline Note: & & & & & & \\
& & & & & & \\
\end{tabular}




\subsection{Robustness}

\subsubsection{Automobile Accidents}

There exist other possible explanations for changes in traffic stops that may not operate through other means than incentives to the law enforcement agencies. One alternative explanation for the main results presented in the traffic stop models is a change in driver behavior opposed to police behavior. For example, if the local newspapers also publish accident reports in addition to police activities, then drivers may become less cautious when driving because they are less concerned about public accountability for their bad behavior. If the newspaper closure is changing driving behavior, or correlated with some latent factor that would affect driver behavior, and the law enforcement are just rationally increasing enforcement then it is likely to appear in accidents. After all, the main objective of law enforcement writing traffic tickets should be roadway safety.

I use the Illinois Roadway Crash Database to rule out alternative hypothesis operating through driver behavior instead of law enforcement incentives. I use the sample years 2011-2018, identical to the traffic stop sample, and replicate Equation 3.2, replacing $Y_{i t}$ with automobile accidents in a county month. There is one caveat, where $i$ represent a county instead of a law enforcement department. I use the treated counties instead of the treated departments because automobile accidents cannot be assigned to specific departments like traffic stops initiated by an officer. I use county fixed effects in lieu of of department fixed effects.

Table 3.7 does not show any statistically significant effects of newspaper closure on accidents in the treated counties relative to counties with no change in newspaper status. Though not significant, the point estimate of -25.5 accidents a month does not suggest any increase in more aggressive or dangerous driving. If anything, the estimate suggests motorist driving safer, potentially stemming from increased law enforcement ticketing activity. This result is consistent with the instrumental variables approach in Makowsky and Stratmann (2011) where municipality fiscal constraints result in reduced automobile accidents. 
Table 3.7: Automobile Accident DiD

\begin{tabular}{lc}
\hline \hline & Dependent variable: \\
\cline { 2 - 2 } & Accidents \\
\hline Closure & $\begin{array}{c}-25.495 \\
(19.896)\end{array}$ \\
\hline YearxMonth FEs & $\mathrm{Y}$ \\
County FEs & $\mathrm{Y}$ \\
\hline Observations & 11,011 \\
$\mathrm{R}^{2}$ & 0.988 \\
Adjusted ${ }^{2}$ & 0.988 \\
Residual Std. Error & $134.298(\mathrm{df}=10801)$ \\
\hline \hline Note: & ${ }^{*} \mathrm{p}<0.1 ;{ }^{* *} \mathrm{p}<0.05 ;{ }^{* * *} \mathrm{p}<0.01$
\end{tabular}

\subsection{Discussion and Conclusion}

There is a robust literature showing the importance of local press in creating accountability for government organizations. This paper has shown that the accountability created by newspapers can extend to non-elected offices as well. Instead of shirking, local police and sheriff departments increase ticketing to residents after a local newspaper closes. The newspaper closure decreases the observability of taxation by citation and bureaucratic incentives drive more ticketing in the form of taxation by citation. An increase of 18 tickets to residents by a department because of newspaper closure results in $\$ 52,000$ more in traffic fines paid by county residents in a year. ${ }^{5}$

This study does have some limitations and further work for robustness is required. First, newspaper circulation is only consider on the extensive margin, open or closed. The intensity of newspaper circulation, as well as the content in the newspaper are also important determinants of government performance based on the press, but this requires further data and investigation. Second, pinning down the exact mechanism that the newspaper operates on law enforcement is important. The changes in traffic stops presented here could come from two possible sources. The law enforcement changing their behavior in response to newspaper closing, or bureaucrats pushing law enforcement to increase ticketing. The later could occur for two reasons, because bureaucrats are simply trying to maximize tax revenue or because they are trying to make up for increased expenses or shortfalls

\footnotetext{
${ }^{5}$ Based on $\$ 120$ average ticket cost.
} 
consistent with the story in Gao, Lee, and Murphy (2018).

Overall, these results lend credence to the growing concern for news deserts in small-town America. I have shown these concerns should extend to law enforcement behavior, not just general corruption, public goods, or misallocation of funds. Small towns with small law enforcement departments are especially resource constrained, having to cover large areas. If law enforcement officers are pushed to engage in more taxation-by-citation, this comes at a cost of responding to other duties. Response times for other calls, such as accidents and domestic violence, could increase, with clear negative welfare implications.

\subsection{Appendix}

To further investigate this effect, I interact the stop purpose with newspaper closure in Table 3.8. Stops are categorized as moving or equipment violations and expired license plates or registration. Equipment violations are the omitted category. The odds of being ticketed for expired paperwork increases by 15 percentage points after the closings. There are additional increases in for miscellaneous

stop purposes while the probability of being stopped for following to close decreases. Officers are more likely to issue a formal citation instead of a warning after the newspaper closing. 
Table 3.8: Individual Stop Models by Stop Purpose

\begin{tabular}{|c|c|c|}
\hline & \multicolumn{2}{|c|}{ Dependent variable: } \\
\hline & $\begin{array}{c}\text { Ticket } \\
(1)\end{array}$ & $\begin{array}{c}\text { Search } \\
(2)\end{array}$ \\
\hline Closure & $\begin{array}{c}0.008 \\
(0.055)\end{array}$ & $\begin{array}{l}0.026^{*} \\
(0.013)\end{array}$ \\
\hline Closure: Traffic Sign & $\begin{array}{l}-0.003 \\
(0.031)\end{array}$ & $\begin{array}{l}-0.016 \\
(0.012)\end{array}$ \\
\hline Closure: License Reg & $\begin{array}{c}0.149^{* * *} \\
(0.025)\end{array}$ & $\begin{array}{c}0.043^{* * *} \\
(0.016)\end{array}$ \\
\hline Closure: Speeding & $\begin{array}{c}0.023 \\
(0.040)\end{array}$ & $\begin{array}{c}-0.031^{* *} \\
(0.012)\end{array}$ \\
\hline Closure: Lane violation & $\begin{array}{c}0.093 \\
(0.059)\end{array}$ & $\begin{array}{c}0.036^{* * *} \\
(0.014)\end{array}$ \\
\hline Closure: Seatbelt & $\begin{array}{c}0.005 \\
(0.079)\end{array}$ & $\begin{array}{c}0.073 \\
(0.046)\end{array}$ \\
\hline Closure: Follow Close & $\begin{array}{c}-0.185^{* * *} \\
(0.059)\end{array}$ & $\begin{array}{c}-0.059^{* *} \\
(0.024)\end{array}$ \\
\hline Closure: Other & $\begin{array}{c}0.075^{* * *} \\
(0.020)\end{array}$ & $\begin{array}{c}0.043^{* * *} \\
(0.013)\end{array}$ \\
\hline Observations & $7,434,598$ & $7,434,598$ \\
\hline $\mathrm{R}^{2}$ & 0.204 & 0.238 \\
\hline Adjusted $\mathrm{R}^{2}$ & 0.204 & 0.238 \\
\hline Residual Std. Error $(\mathrm{df}=7433693)$ & 0.442 & 0.188 \\
\hline
\end{tabular}


Table 3.9: Resident Ticket Lienency Models

\begin{tabular}{|c|c|c|c|}
\hline & \multicolumn{3}{|c|}{ Dependent variable: } \\
\hline & \multicolumn{3}{|c|}{ Ticket } \\
\hline & $(1)$ & $(2)$ & $(3)$ \\
\hline Resident & $\begin{array}{c}-0.043^{* * *} \\
(0.0004)\end{array}$ & $\begin{array}{c}-0.009^{* * *} \\
(0.003)\end{array}$ & $\begin{array}{l}-0.005 \\
(0.003)\end{array}$ \\
\hline Demographics & $\mathrm{N}$ & $\mathrm{Y}$ & $\mathrm{Y}$ \\
\hline Stop Purpose & $\mathrm{N}$ & $\mathrm{N}$ & $\mathrm{Y}$ \\
\hline Department and Time FE & $\mathrm{Y}$ & $\mathrm{Y}$ & $\mathrm{Y}$ \\
\hline Observations & $11,113,898$ & $11,113,898$ & $11,113,898$ \\
\hline $\mathrm{R}^{2}$ & 0.001 & 0.158 & 0.200 \\
\hline Adjusted $\mathrm{R}^{2}$ & 0.001 & 0.158 & 0.200 \\
\hline
\end{tabular}

Table 3.10: Individual Stop Triple Difference Models

\begin{tabular}{lcc}
\hline \hline & \multicolumn{2}{c}{ Dependent variable: } \\
\cline { 2 - 3 } & Ticket & Search \\
& $(1)$ & $(2)$ \\
\hline Resident & $-0.008^{* *}$ & 0.001 \\
& $(0.003)$ & $(0.001)$ \\
Resident:Closure & $0.017^{* * *}$ & $0.007^{*}$ \\
& $(0.006)$ & $(0.004)$ \\
\hline Stop/Demographics & & $\mathrm{Y}$ \\
DepartmentxYearxMonth FEs & $\mathrm{Y}$ & $\mathrm{Y}$ \\
\hline Observations & $7,434,598$ & $7,434,598$ \\
$\mathrm{R}^{2}$ & 0.247 & 0.313 \\
Adjusted R & & 0.308 \\
Residual Std. Error $(\mathrm{df}=7381011)$ & 0.432 & 0.179 \\
\hline \hline Note: & $* \mathrm{p}<0.1 ;{ }^{* *} \mathrm{p}<0.05 ;{ }^{* * *} \mathrm{p}<0.01$
\end{tabular}


Table 3.11: Triple Difference Aggregated Models

\begin{tabular}{|c|c|c|c|}
\hline & \multicolumn{3}{|c|}{ Dependent variable: } \\
\hline & $\begin{array}{c}\text { Stops } \\
(1)\end{array}$ & $\begin{array}{c}\text { Tickets } \\
(2) \\
\end{array}$ & $\begin{array}{c}\text { Searches } \\
(3)\end{array}$ \\
\hline Resident & $\begin{array}{c}67.583^{* * *} \\
(8.646)\end{array}$ & $\begin{array}{c}25.727^{* * *} \\
(4.334)\end{array}$ & $\begin{array}{l}3.424^{* *} \\
(1.458)\end{array}$ \\
\hline Resident:Closure & $\begin{array}{l}-24.275 \\
(25.851)\end{array}$ & $\begin{array}{c}-4.838 \\
(11.966)\end{array}$ & $\begin{array}{c}0.131 \\
(3.008)\end{array}$ \\
\hline Observations & 72,712 & 72,712 & 72,712 \\
\hline $\mathrm{R}^{2}$ & 0.707 & 0.702 & 0.677 \\
\hline Adjusted $\mathrm{R}^{2}$ & 0.382 & 0.371 & 0.317 \\
\hline Residual Std. Error $(\mathrm{df}=34424)$ & 120.348 & 56.899 & 11.070 \\
\hline
\end{tabular}




\section{Bibliography}

Acemoglu, Daron (2006). "A simple model of inefficient institutions". The Scandinavian Journal of Economics 108.4, pp. 515-546.

Acemoglu, Daron and Simon Johnson (2005). "Unbundling institutions". Journal of Political Economy 113.5, pp. 949-995.

Acevedo, Karina and Iván Bornacelly (2016). "Panel Municipal del CEDE". Centro de Estudios sobre Desarrollo Económico.

Albertus, Michael and Oliver Kaplan (2013). "Land Reform as a Counterinsurgency Policy". Journal of Conflict Resolution 57.2, pp. 198-231.

Alpert, Megan (2016). Politics roils Colombia's tentative peace deal with the FARC.

Alston, Lee J, Gary D Libecap, and Bernardo Mueller (1999). "A model of rural conflict: violence and land reform policy in Brazil". Environment and Development Economics 4.2, pp. 135-160.

Alston, LJ, GD Libecap, and B Mueller (2000). "Land reform policies, the sources of violent conflict, and implications for deforestation in the Brazilian Amazon". Journal of Environmental Economics and Management 39.2.

Anderson, D Mark (2010). "Does information matter? The effect of the Meth Project on meth use among youths". Journal of Health Economics 29.5, pp. 732-742.

Antonovics, Kate and Brian G Knight (2009). "A new look at racial profiling: Evidence from the Boston Police Department". The Review of Economics and Statistics 91.1, pp. 163-177.

Anwar, Shamena and Hanming Fang (2006). "An alternative test of racial prejudice in motor vehicle searches: Theory and evidence". The American economic review 96.1, pp. 127-151. 
Atwater, Montgomery Meigs (1968). The Avalanche Hunters. Macrae Smith Co.

Avalanche Canada (2019). Annual Report.

Baicker, Katherine and Mireille Jacobson (2007). "Finders keepers: Forfeiture laws, policing incentives, and local budgets". Journal of Public Economics 91.11, pp. 2113-2136.

Bakermans, Laura and Bruce Jamieson (2009). "SWarm: A simple regression model to estimate near-surface snowpack warming for back-country avalanche forecasting". Cold Regions Science and Technology 59.2-3, pp. 133-142.

Bartelt, Perry and Michael Lehning (2002). "A physical SNOWPACK model for the Swiss avalanche warning: Part I: numerical model". Cold Regions Science and Technology 35.3, pp. 123-145.

Barthel, Michael (2017). "Circulation, Revenue Fall for US Newspapers Overall despite Gains for Some". Pew Research Reports.

Becker, Gary S (1968). "Crime and Punishment: An Economic Approach". Journal of Political Economy 76.2, pp. 169-217.

Bellaire, Sascha et al. (2017). "On forecasting wet-snow avalanche activity using simulated snow cover data". Cold Regions Science and Technology 144, pp. 28-38.

Benson, Bruce L (1988). "Legal evolution in primitive societies". Journal of Institutional and Theoretical Economics, pp. 772-788.

Benson, Bruce L and Zafar R Siddiqui (2014). "Pashtunwali-Law for the lawless, defense for the stateless". International Review of Law and Economics 37, pp. 108-120.

Bertrand, Marianne and Adair Morse (2011). "Information disclosure, cognitive biases, and payday borrowing". The Journal of Finance 66.6, pp. 1865-1893.

Besley, Timothy (1995). "Property rights and investment incentives: Theory and evidence from Ghana". Journal of Political Economy 103.5, pp. 903-937.

Bjørnskov, Christian and Andreas Freytag (2016). "An offer you can’t refuse: murdering journalists as an enforcement mechanism of corrupt deals". Public Choice 167.3, pp. 221-243. ISSN: 1573-7101. Bradshaw, Karen and Dean Lueck (2012). Wildfire policy: Law and economics perspectives. Routledge. 
Brasselle, Anne-Sophie, Frederic Gaspart, and Jean-Philippe Platteau (2002). "Land tenure security and investment incentives: Puzzling evidence from Burkina Faso". Journal of Development Economics 67.2, pp. 373-418.

Brewer, Noel T et al. (2016). "Effect of pictorial cigarette pack warnings on changes in smoking behavior: a randomized clinical trial". JAMA internal medicine 176.7, pp. 905-912.

Brittain, James J. (2010). Revolutionary social change in Colombia: the origin and direction of the FARC-EP. Pluto Press.

Brunner, Eric, Jon Sonstelie, and Mark Thayer (2001). "Capitalization and the voucher: an analysis of precinct returns from California's Proposition 174". Journal of Urban Economics 50.3, pp. 517-536.

Carpenter, Christopher S and Mark Stehr (2008). "The effects of mandatory seatbelt laws on seatbelt use, motor vehicle fatalities, and crash-related injuries among youths". Journal of Health Economics 27.3, pp. $642-662$.

Carpenter, Christopher S and Casey Warman (2019). "What Do Bicycle Helmet Laws Do? Evidence from Canada". Economic Inquiry 57.2, pp. 832-854.

Chen, Chaoran (2017). "Untitled land, occupational choice, and agricultural productivity". American Economic Journal: Macroeconomics 9.4, pp. 91-121.

Clark, JR and Dwight R Lee (1997). "Too safe to be safe: Some implications of short-and long-run rescue Laffer Curves". Eastern Economic Journal 23.2, pp. 127-137.

Cohen, Alma and Liran Einav (2003). "The effects of mandatory seat belt laws on driving behavior and traffic fatalities". Review of Economics and Statistics 85.4, pp. 828-843.

Colombian State Department (2016). Election Results.

Colorado Supreme Court (2016). Fleury v. IntraWest Winter Park Operations Corp.

Coyne, Christopher J and Peter T Leeson (2009). "Media as a mechanism of institutional change and reinforcement". Kyklos 62.1, pp. 1-14.

De Janvry, Alain et al. (2015). "Delinking land rights from land use: Certification and migration in Mexico". The American Economic Review 105.10, pp. 3125-3149. 
De Soto, Hernando (1989). The other path: The economic answer to terrorism. Harper \& Row New York.

- (2000). The mystery of capital: Why capitalism triumphs in the West and fails everywhere else. Basic Civitas Books.

DeAngelo, Gregory and Benjamin Hansen (2014). "Life and death in the fast lane: Police enforcement and traffic fatalities". American Economic Journal: Economic Policy 6.2, pp. 231-57.

Dehring, Carolyn A, Craig A Depken, and Michael R Ward (2008). "A direct test of the homevoter hypothesis". Journal of Urban Economics 64.1, pp. 155-170.

Di Tella, Rafael, Sebastian Galiant, and Ernesto Schargrodsky (2007). "The formation of beliefs: Evidence from the allocation of land titles to squatters". The Quarterly Journal of Economics 122.1, pp. 209-241.

Dixit, Avinash (1997). "Power of incentives in private versus public organizations". The American Economic Review 87.2, pp. 378-382.

Dyck, Alexander, Adair Morse, and Luigi Zingales (2010). "Who blows the whistle on corporate fraud?" The Journal of Finance 65.6, pp. 2213-2253.

Ehrlich, Isaac (1996). "Crime, punishment, and the market for offenses". Journal of Economic Perspectives 10.1, pp. 43-67.

Fajardo, Darío et al. (2002). "La tierra y el poder político; la reforma agraria y la reforma rural en Colombia".

Ferrell, Perry, Josh Matti, and Bryan McCannon (2019). "Votes or Violations: Enforcement Cycles in Sheriff Elections".

Field, Erica (2007). "Entitled to work: Urban property rights and labor supply in Peru". The Quarterly Journal of Economics 122.4, pp. 1561-1602.

Fischel, William A (2001). The homevoter hypothesis: How home values influence local government taxation, school finance, and land-use policies. Harvard University Press Cambridge, MA. 
Furman, Nate, Wynn Shooter, and Scott Schumann (2010). "The roles of heuristics, avalanche forecast, and risk propensity in the decision making of backcountry skiers". Leisure Sciences 32.5, pp. $453-469$.

Galiani, Sebastian and Ernesto Schargrodsky (2010). "Property rights for the poor: Effects of land titling". Journal of Public Economics 94.9, pp. 700-729.

Gao, Pengjie, Chang Lee, and Dermot Murphy (2018). "Financing dies in darkness? The impact of newspaper closures on public finance".

Garrett, Thomas A and Gary A Wagner (2009). "Red ink in the rearview mirror: Local fiscal conditions and the issuance of traffic tickets". The Journal of Law and Economics 52.1, pp. 71-90.

Gehrsitz, Markus (2017). "Speeding, Punishment, and Recidivism: Evidence from a Regression Discontinuity Design". The Journal of Law and Economics 60.3, pp. 497-528.

Gentzkow, Matthew, Jesse M Shapiro, and Michael Sinkinson (2011). "The effect of newspaper entry and exit on electoral politics". American Economic Review 101.7, pp. 2980-3018.

Glaeser, Edward, Jose Scheinkman, and Andrei Shleifer (2003). "The injustice of inequality". Journal of Monetary Economics 50.1, pp. 199 -222. ISSN: 0304-3932.

Goldstein, Markus and Christopher Udry (2008). "The profits of power: Land rights and agricultural investment in Ghana". Journal of Political Economy 116.6, pp. 981-1022.

Goncalves, Felipe and Steven Mello (2017). "Does the punishment fit the crime? Speeding fines and recidivism". Working Paper.

- (2018). "A Few Bad Apples? Racial Bias in Policing". Working Paper.

Grusczynski, Diana Michelle and C Felipe Jaramillo (2002). "Integrating land issues into the broader development agenda. Case Study: Colombia".

Haegeli, Pascal et al. (2010). "Amateur decision-making in avalanche terrain with and without a decision aid: a stated choice survey". Natural Hazards 52.1, p. 185.

Hendrikx, Jordy and Jerry Johnson (2014). "Using global crowd-sourced data to understand travel behavior in avalanche terrain". Proceedings of the 2014 International Snow Science Workshop. 
Ibanez, Ana Maria et al. (2009). "Forced displacement in Colombia: Magnitude and causes". The Economics of Peace and Security Journal 4.1, pp. 48-54.

Illinois Traffic and Pedestrian Stop Study.

Janvry, Alain De, Marco Gonzalez-Navarro, and Elisabeth Sadoulet (2014). "Are land reforms granting complete property rights politically risky? Electoral outcomes of Mexico's certification program". Journal of Development Economics 110, pp. 216 -225.

Kerekes, Carrie B and Claudia R Williamson (2010). "Propertyless in Peru, even with a government land title". American Journal of Economics and Sociology 69.3, pp. 1011-1033.

Lazar, Brian et al. (2016). "North American avalanche danger scale: Do backcountry forecasters apply it consistently". Proceedings ISSW, pp. 457-465.

Leech, Garry M. (2011). The FARC: the longest insurgency. Rebels. Fernwood.

Leeson, Peter T (2007). "Trading with bandits". The Journal of Law and Economics 50.2, pp. 303-321.

- (2009). "The laws of lawlessness". The Journal of Legal Studies 38.2, pp. 471-503.

- (2012). "“God Damn”: The Law and Economics of Monastic Malediction”. The Journal of Law, Economics, \& Organization 30.1, pp. 193-216.

— (2013). "Gypsy law". Public Choice 155.3-4, pp. 273-292.

Leeson, Peter T. and Colin Harris (2018). "Wealth-destroying private property rights". World Development 107, pp. 1 -9. ISSN: 0305-750X.

Levy-Carciente, Sary (2017). International Property Rights Index. Property Rights Alliance.

Lim, Claire SH, James M Snyder Jr, and David Strömberg (2015). "The judge, the politician, and the press: newspaper coverage and criminal sentencing across electoral systems". American Economic Journal: Applied Economics 7.4, pp. 103-35.

Logan, Spencer and Frank Witmer (2012). "Spatial, temporal, and space-time analysis of fatal avalanche accidents in Colorado and the United States, 1991 to 2011". Proceedings of the 2012 International Snow Science Workshop, September 16-21.

Luca, Dara Lee (2015). "Do traffic tickets reduce motor vehicle accidents? Evidence from a natural experiment". Journal of Policy Analysis and Management 34.1, pp. 85-106. 
Lueck, Dean (2012). "Economics and the organization of wildfire suppression". Wildfire policy: Law and Economics perspectives, pp. 71-88.

Maciag, Mike (2019). Addicted to Fines.

Makowsky, Michael D and Thomas Stratmann (2009). "Political economy at any speed: what determines traffic citations?" The American Economic Review 99.1, pp. 509-527.

- (2011). "More tickets, fewer accidents: How cash-strapped towns make for safer roads". The Journal of Law and Economics 54.4, pp. 863-888.

McCammon, Ian and Pascal Hägeli (2004). "Comparing avalanche decision frameworks using accident data from the United States". International Snow Science Workshop, Jackson, WY.

McCarthy, Patrick and Wayne K Talley (2001). "Safety investments, behaviours and injury severity". Applied Economics 33.6, pp. 701-710.

Michel-Kerjan, Erwann O (2010). "Catastrophe economics: the national flood insurance program". Journal of Economic Perspectives 24.4, pp. 165-86.

Mondak, Jeffery J (1995). "Newspapers and political awareness". American Journal of Political Science, pp. 513-527.

Murtazashvili, Ilia and Jennifer Murtazashvili (2015). "Anarchy, self-governance, and legal titling". Public Choice 162.3, pp. 287-305.

Olson, Mancur (2008). The rise and decline of nations: Economic growth, stagflation, and social rigidities. Yale University Press.

Otis, John (2014). "The FARC and Colombia's illegal drug trade". Woodrow Wilson Center: Encyclopedia of U.S.-Latin American Relations.

Palacios, Paola (2012). "Forced Displacement: Legal Versus Illegal Crops". Defence and Peace Economics 23.2, pp. 133-160.

Polinsky, A Mitchell and Steven Shavell (1992). "Enforcement costs and the optimal magnitude and probability of fines". The Journal of Law and Economics 35.1, pp. 133-148.

Quintanar, Sarah Marx (2017). "Man vs. machine: An investigation of speeding ticket disparities based on gender and race". Journal of Applied Economics 20.1, pp. 1-28. 
Registro Único de Víctimas (2016). Colombian Register of Victims Report.

Richani, Nazih (2013). Systems of violence: the political economy of war and peace in Colombia. Suny Press.

Robinson, James A (2016). "La miseria en Colombia". Revista Desarrollo y Sociedad 76, pp. 9-88.

Romero, Dennis and Elisha Fieldstadt (2019). Skier buried by New Mexico avalanche dead, another in critical condition.

Santos Calderón, Juan Manuel and Timoleón Jiménez (2016). Acuerdo Final Para la Terminación del Conflicti y la Construcción de una Paz Estable y Duradera. Oficina del Alto Comisionado para la Paz.

Skaperdas, Stergios (1992). "Cooperation, conflict, and power in the absence of property rights". The American Economic Review 82.4, pp. 720-739.

SLF Switzerland. Origins of the avalanche bulletin - history and background. https://www.slf.ch/en/aboutthe-slf/portrait/history/origins-of-the-avalanche-bulletin.html.

Snyder Jr, James M and David Strömberg (2010). "Press coverage and political accountability". Journal of political Economy 118.2, pp. 355-408.

Sonin, Konstantin (2003). "Why the rich may favor poor protection of property rights". Journal of Comparative Economics 31.4, pp. 715 -731. ISSN: 0147-5967.

Statham, Grant et al. (2010). "The North American public avalanche danger scale". 2010 International Snow Science Workshop, pp. 117-123.

Stringham, Edward (2015). Private governance: Creating order in economic and social life. Oxford University Press, USA.

Stuart, Ryan (2017). How Many Backcountry Skiers Are Out There?

Su, Min (2020). "Taxation by Citation? Exploring Local Governments' Revenue Motive for Traffic Fines". Public Administration Review 80.1, pp. 36-45.

Techel, Frank et al. (2016). "Avalanche fatalities in the European Alps: long-term trends and statistics". Geographica Helvetica 71.2, pp. 147-159.

Tullock, Gordon (1975). "The transitional gains trap". The Bell Journal of Economics, pp. 671-678. 
Williams, Knox (1998). "An overview of avalanche forecasting in North America". Proceedings of the international snow science workshop, Sunriver, OR, ISSW Workshop Committee, pp. 161-169.

Williamson, Claudia R. and Rachel L. Mathers (2011). "Economic freedom, culture, and growth". Public Choice 148.3, pp. 313-335.

Willsher, Kim (2017). "Mont Blanc: mayor tries to stop ill-equipped 'hotheads' tackling peak". The Guardian.

Wilson, Lori (2018). Doraville residents file federal lawsuit to fight 'excessive' fines and fees.

World Values Survey Association (2010-2014). World Value Survey Wave 6. World Value Survey.

Yazaki, Yukihiro (2017). "Newspapers and political accountability: evidence from Japan". Public Choice 172.3, pp. 311-331. ISSN: 1573-7101.

Yoder, Jonathan (2008). "Liability, regulation, and endogenous risk: the incidence and severity of escaped prescribed fires in the United States". The Journal of Law and Economics 51.2, pp. 297325.

Zou, Hui and Trevor Hastie (2005). "Regularization and variable selection via the elastic net". Journal of the Royal Statistical Society: Series B (Statistical Methodology) 67.2, pp. 301-320. 